NBER WORKING PAPER SERIES

\author{
THE LOAN COVENANT CHANNEL: \\ HOW BANK HEALTH TRANSMITS TO THE REAL ECONOMY \\ Gabriel Chodorow-Reich \\ Antonio Falato \\ Working Paper 23879 \\ http://www.nber.org/papers/w23879
}

\author{
NATIONAL BUREAU OF ECONOMIC RESEARCH \\ 1050 Massachusetts Avenue \\ Cambridge, MA 02138 \\ September 2017
}

We thank Dan Andrews (discussant), Indraneel Chakraborty (discussant), Arpit Gupta (discussant), Marcel Jansen (discussant), Justin Murfin (discussant), Michael Roberts (discussant), David Scharfstein, Andrei Shleifer, Jeremy Stein, Amir Sufi, participants at the 2017 St. Louis Fed STLAR conference, 2017 Bank Of Spain Conference on Financial Stability, the 2017 NBER ME summer meeting, the 2017 Advances in Macro Finance Tepper-Laef Conference, the 2017 NBER CF fall meeting, the 2018 IMF Annual Macro-Financial Research Conference, the 2018 NYU/Stern Conference on Financial Intermediation, the 2019 AEA meetings, and seminar participants at Columbia University, Federal Reserve Bank of San Francisco, London Business School, MIT, NOVA School of Business and Economics, Ohio State, Stanford, UCLA Anderson, U. of Chicago, and UT Austin for helpful comments and Ivan Ivanov for sharing snow cover data with us. The views expressed herein are those of the authors and not necessarily those of the Federal Reserve Board of Governors, the Federal Reserve System, or the National Bureau of Economic Research.

NBER working papers are circulated for discussion and comment purposes. They have not been peerreviewed or been subject to the review by the NBER Board of Directors that accompanies official NBER publications.

(C) 2017 by Gabriel Chodorow-Reich and Antonio Falato. All rights reserved. Short sections of text, not to exceed two paragraphs, may be quoted without explicit permission provided that full credit, including (C) notice, is given to the source. 
The Loan Covenant Channel: How Bank Health Transmits to the Real Economy

Gabriel Chodorow-Reich and Antonio Falato

NBER Working Paper No. 23879

September 2017, Revised June 2020

JEL No. E44,G21,G32

\begin{abstract}
$\underline{\text { ABSTRACT }}$
We document the importance of covenant violations in transmitting bank health to non-financial firms using a new supervisory data set of bank loans. Roughly one-third of loans in our data breach a covenant during the 2008-09 period, providing lenders the opportunity to force a renegotiation of loan terms or to accelerate repayment of otherwise long-term credit. Lenders in worse health are more likely to force a reduction in the loan commitment following a violation. The reduction in credit to borrowers who violate a covenant accounts for the majority of the cross-sectional variation in credit supply during the 2008-09 crisis.
\end{abstract}

\author{
Gabriel Chodorow-Reich \\ Department of Economics \\ Harvard University \\ 1805 Littauer Center \\ Cambridge, MA 02138 \\ and NBER \\ chodorowreich@fas.harvard.edu
}

Antonio Falato

Federal Reserve Board

Mail Stop \#89

20th Street \& Constitution Ave. NW

Washington DC 20551

antonio.falato@frb.gov 


\section{Introduction}

A large literature documents the importance of the health of the banking sector for nonfinancial firm outcomes such as investment and employment. ${ }^{1}$ Most recently, the 2008-09 period contained both a financial crisis and the deepest recession in the United States in 60 years. Yet, at the start of the financial panic in 2008 only $10 \%$ of bank loans had remaining maturity of less than one year and the typical firm did not face the prospect of a maturing bank loan until 2011. This fact reveals an important gap in our understanding of the transmission of bank health: why do shocks to lenders affect their existing corporate borrowers despite the prevalence of long-term credit?

We document the central role of loan covenant violations in this transmission mechanism. Loan covenants appear in nearly all commercial loan contracts. They circumscribe the set of actions a borrower may take (nonfinancial covenants) or specify minimum or maximum thresholds for cash flow or balance sheet variables (financial covenants). Breaching of a covenant puts a borrower into technical default and gives the lender the right to accelerate repayment of the loan. Thus, loan covenant violations increase lenders' bargaining power and provide them broad opportunity to renegotiate contract terms when their internal cost of funds rises. As a result, covenant violations allow lenders to reduce the existing stock of credit, potentially affecting many more borrowers than just those with expiring credit or seeking new originations. We refer to the transmission of lender health to existing borrowers through the forced renegotiation of contract terms as the loan covenant channel.

We assess the covenant channel in the context of the 2008-09 financial crisis using a new supervisory data set of covenant compliance in syndicated loans. We observe the identities of borrowers and lenders and follow individual loans over time, including through amendments. Following the violation of a covenant, a lender may accelerate repayment, force a renegotiation of the loan contract, or simply waive or reset the covenant with no further impact on the loan. Our data track each of these potential outcomes.

We document two key facts using these data: most bank loans have long stated maturity, but many loans breach covenants. Our full data set covers $\$ 2$ trillion of loan commitments at the start of 2008 . Of these, $91 \%$ have at least one year maturity remaining and the mean maturity remaining

\footnotetext{
${ }^{1}$ See e.g. Peek and Rosengren (2000), Lin and Paravisini (2012), Chodorow-Reich (2014), and Benmelech, Bergman, and Seru (2015) for evidence from the United States and Gan (2007), Amiti and Weinstein (2018), and Bentolila, Jansen, and Jiménez (2017) for evidence in other countries.
} 
within this group is 3.3 years. Roughly one-quarter of loans in the data breach a covenant during a typical year before the 2008-09 financial crisis and one-third of loans breach a covenant each year during the financial crisis. Together, long stated maturity but high violation frequency make the loan covenant channel a potentially important transmission mechanism.

For a causal assessment of the covenant channel we turn to variation in the cross-section of lenders during the 2008-09 financial crisis. The write-downs on assets linked to real estate loans led to an enormous decline in the market equity of the U.S. financial sector and coincided with a sharp increase in bank funding costs. Both factors increased the internal cost of funds at lenders. A body of evidence documents the transmission from the reduction in credit supply at lenders to outcomes at nonfinancial firms during the crisis (Campello, Graham, and Harvey, 2010; Duchin, Ozbas, and Sensoy, 2010; Campello, Giambona, et al., 2011; Chodorow-Reich, 2014; Duygan-Bump, Levkov, and Montoriol-Garriga, 2015; Siemer, 2016). However, banks varied greatly in their exposure to the crisis. We assign lender health by combining three measures used in Chodorow-Reich (2014) that capture a bank's exposure to the crisis through counterparty risk and mortgage-related losses.

Our empirical exercises ask whether the outcome of a covenant violation during the 2008-09 crisis depended on the lead lender's financial health. A simple comparison of outcomes of violations based on lender health raises two main concerns. First, firms that violate covenants and have unhealthy lenders may differ along other dimensions from firms that violate covenants and have healthier lenders. We attempt to assuage this concern by presenting evidence that borrowers of healthier and less healthy lenders appear similar along numerous observable dimensions including pre-crisis leverage, risk rating, and ex ante covenant tightness, have similar propensities to violate a covenant during the crisis, and that the balancing of observable characteristics holds even within the subset of firms that violate covenants. The second concern is that violation of a covenant correlates with other firm characteristics and loan outcomes may also depend on the interplay of lender health and these other characteristics. We address this concern by including as covariates in our main specification measures of borrower quality interacted with lender health, which isolate the impact of lender health $\times$ violation from the impact of lender health $\times$ borrower quality.

We also offer two additional causal identification strategies. The first follows an influential literature using regression discontinuity methods to study the impact of covenant violations on firms (Chava and Roberts, 2008; Roberts and Sufi, 2009a; Nini, Smith, and Sufi, 2012; Falato and Liang, 2016). We provide conditions under which this analysis causally identifies the treatment 
effect of a violation separately for borrowers of healthy and less healthy lenders, even if the overall distribution of borrowers or of covenant violators differs across lender type. The second is an instrumental variables design with covenant violation status an endogenous variable. We introduce four excluded instruments for covenant status: (i) the opening of a new airline route that reduces the travel time between the lender's and borrower's headquarters, which, similar to Giroud (2013) and Bernstein, Giroud, and Townsend (2016), allows lenders to substitute monitoring for covenant tightness, reducing violation propensities during the crisis; (ii) the bankruptcy of an airline servicing the primary route connecting the headquarter cities, which increases travel time and has the opposite effect to a new route; (iii) the strictness of the lender's supervisor at the time of origination, similar to Agarwal et al. (2014); and (iv) abnormal snow cover in the borrower's county, which Brown, Gustafson, and Ivanov (forthcoming) show predicts earnings.

Across all of our research designs, we find strong evidence of less healthy lenders using covenant violations to contract credit. Conditional on breaching a threshold, the likelihood of a reduction in the loan commitment rises by more than 20 p.p. for borrowers of the least healthy lenders relative to the healthiest lenders and the average loan size falls an additional 25 to $30 \%$. Affected borrowers appear unable to substitute toward alternative sources of credit, reflecting the difficulty of obtaining new credit while in technical default. Instead, these borrowers increase the utilization on their existing credit lines, reduce payouts, and reduce investment and employment relative to firms that violate a covenant but have a healthier lender. The impact on real outcomes echoes previous literature, which has found an adverse effect of a covenant violation on debt issuance (Roberts and Sufi, 2009a; Nini, Smith, and Sufi, 2012), investment (Chava and Roberts, 2008; Nini, Smith, and Sufi, 2012), and employment (Falato and Liang, 2016), but with the added twist that the health of the lender crucially affects the consequences for the borrower.

A number of additional results support the causal interpretation of these findings. First, unhealthy lenders do not reduce credit to borrowers with long-term credit who do not violate a covenant, suggesting that borrowers of less healthy lenders did not experience a correlated decline in loan demand. Second, adding borrower and loan-level controls and interactions of borrower and lender health measures increases the explanatory power of the regressions, but the point estimates remain extremely stable. Third, we obtain similar second stage coefficients across sets of excluded instruments that capture very different sources of variation in the propensity to violate. Fourth, the lead lender's share of the loan commitment declines after a violation if the lead has poor 
health, providing "within-loan" evidence that what shifts is the lead lender's credit supply. Fifth, we conduct placebo exercises and find no differential treatment of borrowers who breach a covenant in 2006-07 based on lender health in 2008-09. Finally, we show robustness to plausible alternative definitions of lender health and to sample composition.

We evaluate the macroeconomic importance of the loan covenant channel as follows. A partial equilibrium aggregation of our loan-level regressions, weighted to be representative of the universe of syndicated loans, finds that total loan commitments contracted by $4.9 \%$ in 2008 and $5.2 \%$ in 2009 solely as the result of borrowers who started the year with a long-term loan contract but nonetheless had their borrowing limit lowered by an unhealthy lender following a covenant violation. The same aggregation exercise applied to a bank-level regression finds contractions of $8.6 \%$ in 2008 and $6.1 \%$ in 2009 relative to if each bank behaved the same as the healthiest lender along all margins, including expiring and new credit. Therefore, the contraction due to the covenant channel accounts for a large share of the total cross-sectional variation in lender credit supply.

We discuss related literature next. Section 2 provides institutional background on covenants. Section 3 describes the supervisory data and documents the maturity of bank credit and the prevalence of covenant violations. Section 4 introduces the lender health measures and the crosslender empirical strategy. Section 5 reports borrower and loan-level effects of lender health on the outcome of a covenant violation. Section 6 contains the aggregation exercise. Section 7 concludes.

Related literature. The main contribution of our paper is to establish the importance of covenant violations to the contraction in bank credit supply during the 2008-09 financial crisis. This finding relates to a number of strands of previous literature.

First, a tradition tracing to Bernanke (1983) studies the importance of bank credit supply contractions and firm-bank relationships during financial crises. This literature finds a rapid transmission from lender health to firms; for example, Chodorow-Reich (2014) finds borrowers of lenders in worse health during the 2008-09 financial crisis had lower employment within 9 months of the Lehman Brothers bankruptcy. The prevalence of long-term contracts poses a challenge for this literature insofar as they insulate borrowers from the health of their lender. Earlier work such as Huang (2010) has found suggestive evidence of the availability of pre-committed lines of credit being sensitive to lender health during the financial crisis, but has not established a mechanism through which this occurs. Other explanations for the rapid transmission from 
lender health to borrower outcomes include lumpiness or granularity in the economy together with strong effects in the subset of borrowers needing to refinance or new credit (Almeida, Campello, Laranjeira, et al., 2012; Benmelech, Bergman, and Seru, 2015; Siemer, 2016) and precautionary saving by firms anticipating future credit contraction (Almeida, Campello, and Weisbach, 2004; Bacchetta, Benhima, and Poilly, 2014; Melcangi, 2016; Xiao, 2017). We view these channels as complementary and our contribution as establishing a novel mechanism and highlighting its quantitative importance. For instance, while maturing credit and a covenant violation both allow a lender to end its relationship with a borrower, in 2008 and 2009 three times as many loans in our data had covenant violations as reached the final year of their maturity. Since lower quality borrowers are more likely to violate covenants, the covenant channel also can account for the common empirical finding that the effects of bank health concentrate on smaller, lower quality borrowers. Methodologically, our paper follows much of this literature in using cross-sectional variation in lender health to distinguish contractions in credit due to lender supply from those due to borrower demand.

A second literature documents the negative consequences to the firm of violating a covenant (Chava and Roberts, 2008; Roberts and Sufi, 2009a; Nini, Smith, and Sufi, 2012; Falato and Liang, 2016). Our results suggest that the overall effects reported in these studies may understate the economic importance of covenant violations in bad times, because they mask important response heterogeneity based on the health of the lender. Acharya et al. (2017) also find evidence of heterogeneity in independent and contemporaneous work based on amendments reported in DealScan. Their results complement ours by showing the impact on spreads and fees, variables not available in SNC. On the other hand, superior measurement of covenant violations and subsequent changes in credit in SNC produce much sharper results on the contraction in loan commitments and permit a comparison of the covenant channel to the overall contraction in credit supply by banks.

A third related literature concerns the renegotiation of debt contracts and the purpose and consequences of covenants. This literature has traditionally viewed covenants as a means to overcome the agency problem inherent in lending contracts by limiting the possible actions taken by the borrower and shifting control to the lender if the borrower's financial condition deteriorates (Aghion and Bolton, 1992; Nini, Smith, and Sufi, 2009; Gârleanu and Zwiebel, 2009; Acharya et al., 2014; Bradley and Roberts, 2015). Yet, covenant violations occur routinely and lenders often provide waivers for the violation while taking minimal additional action. Our work complements 
the borrower-centric view by showing that covenants also allow lenders to adjust loan terms when lender health deteriorates, consistent with the symmetric view of incomplete contracting in Hart and Moore (1988). More broadly, almost all long-term debt contracts undergo renegotiation prior to maturity (Roberts and Sufi, 2009b; Denis and Wang, 2014; Roberts, 2015; Mian and Santos, 2018). While this literature has found evidence of borrower characteristics affecting the timing and outcome of such negotiations, our results emphasize the role of lender health in such renegotiations, as in Murfin (2012).

Finally, a macroeconomic literature studies the link between banks and the real economy in dynamic general equilibrium models (Gertler and Kiyotaki, 2010; He and Krishnamurthy, 2013; Brunnermeier and Sannikov, 2014). These models typically assume one period or continuously updated contracts, in contradiction to the long face-value maturity of most debt. Our results provide some justification for this simplification by showing that even long-term contracts have de facto much shorter horizons due to loan covenants. Our evidence also points to lender health affecting the allocation as well as the quantity of credit, an aspect that has received less attention but could substantially impact the welfare implications of these models.

\section{Institutional Background}

This section provides a brief overview of covenants in loan contracts. We highlight two features most relevant to the existence of a loan covenant channel. First, absent a covenant violation, missed payment, or unusual circumstance, a lender cannot renege on a loan commitment before the stated maturity. Second, the violation of a covenant gives the lenders the right but not the obligation to terminate the loan, including forcing immediate repayment of any outstanding principal and interest.

We use an actual loan contract to illustrate these features. In October 2006, Lifetime Brands, Inc. and a lending syndicate with HSBC as the administrative agent agreed to extend the maturity of a credit line to April 2011. ${ }^{2}$ Section 2 of the contract specifies the obligations of the lenders: "Subject to the terms and conditions set forth herein, each Lender having a Revolving Commitment agrees to make Revolving Loans to the Borrower (p.18)." That is, as long as the borrower remains

\footnotetext{
${ }^{2}$ As a public company, Lifetime Brands filed a copy of the agreement with the SEC (https://www.sec.gov/ Archives/edgar/data/874396/000091068006001052/ex99-1_f8k10312006.htm, accessed July 20, 2017).
} 
compliant with the terms of the loan, the lenders must provide funds.

Table A.1 lists the covenants in the agreement. The left panel lists affirmative covenants, actions which the borrower must take to remain compliant. These include providing timely financial statements and maintaining fire insurance on the firm's properties holdings. The right panel lists negative covenants. Many of these, such as restrictions on other borrowing, have in common with the affirmative covenants that compliance is directly under the borrower's control.

Most important to our study are two financial covenants, leverage ratio and interest coverage ratio, which may be violated due to changes in financial conditions not directly under the borrower's control. As defined in sections 1.01, 7.12, and 7.13 of the agreement, the leverage ratio covenant proscribes the ratio of consolidated senior secured debt to a four-quarter trailing movingaverage of consolidated ebitda (earnings before interest, tax, depreciation and amortization) from exceeding 3:1 except following an acquisition approved by the lenders, while the interest coverage ratio covenant prohibits the ratio of the four-quarter trailing moving average of ebitda to interest expense to be less than 4:1 at the end of any fiscal quarter. For these covenants, a decline in earnings could cause an involuntary violation by the borrower.

Section 8 of the agreement defines default and the remedies available to the lender. Events of default include failure to make a principal or interest payment on a loan $(8.01(\mathrm{a}-\mathrm{c}, \mathrm{f}, \mathrm{j}))$, the filing of an involuntary or voluntary bankruptcy petition on behalf of the borrower $(8.01(\mathrm{~h}, \mathrm{i}))$, and, crucially, if "the Borrower shall fail to observe or perform any covenant, condition or agreement contained in Sections 6.02, 6.03, 6.08, 6.11, 6.12, 6.13 or 6.14 or in Article 7" (8.01(d), p.56). Section 8.02 (p.58) specifies contract remedies:

(a) "in the case of an Event of Default specified in Section 8.01(h) or 8.01(i) [i.e. a bankruptcy filing], without declaration or notice to the Borrower, the Revolving Commitments (including the Letter of Credit Commitment) shall immediately and automatically terminate, and the Loans, all accrued and unpaid interest thereon and all other amounts owing under the Loan Documents shall immediately become due and payable, and

(b) in all other cases, upon the direction of the Required Lenders, the Administrative Agent shall, by notice to the Borrower, declare all of the Revolving Commitments (including the Letter of Credit Commitment) to be terminated forthwith, whereupon such Revolving Commitments (including the Letter of Credit Commitment) shall immediately terminate, or declare the 
Loans, all accrued and unpaid interest thereon and all other amounts owing under the Loan Documents to be due and payable forthwith, whereupon the same shall immediately become due and payable."

Thus, under section 8.02(b) a covenant violation gives lenders the right but not the obligation to terminate the credit line and make any outstanding amounts immediately payable. This discretion makes lender health potentially relevant to the resolution of a covenant violation. ${ }^{3}$

\section{Data on Covenant Compliance and Loan Outcomes}

Our data on loan contracts and covenant compliance come from the Shared National Credit Program (SNC). We describe the main features here and provide additional details in the online appendix. We then present two key facts concerning the maturity of bank credit and the prevalence of covenant violations.

\section{1. $\mathrm{SNC}$}

The Shared National Credit Program (SNC) is a confidential supervisory data set jointly administered by the Federal Reserve, FDIC, and OCC. SNC collects information on all loans of at least $\$ 20$ million shared by three or more unaffiliated financial institutions under the regulatory purview of one of the SNC administrators. For each loan, we observe the borrower, loan type, drawn and undrawn balance on December 31st of the reporting year, and the ownership shares of the syndicate lead lender and all participants, including institutions not regulated by a SNC supervisor. Unlike the Thomson Reuters DealScan database, SNC maintains a single loan identifier through subsequent modifications and refinancings. ${ }^{4}$ Still, very large changes in loan terms may

\footnotetext{
${ }^{3}$ The subsequent evolution of this particular loan agreement has anecdotal value in illustrating the covenant channel. Recall the stated maturity provided a credit line through April 2011. According to the firm's FY2008 10K filing (https://www.sec.gov/Archives/edgar/data/874396/000091068009000143/f10k12312008.htm, pp. $8,21)$, the lenders agreed to modify the covenant terms and thresholds in March and September 2008 in anticipation of declining firm sales. Even so, the firm violated one of the revised covenants in December 2008. In March 2009 the firm signed an amended agreement, which again modified the covenant terms and thresholds and reduced the maximum amount borrowable under the agreement.

${ }^{4}$ The official term for the unit of observation in the SNC data set is a credit. A credit may consist of multiple facilities jointly arranged by the same syndicate and signed on the same date. The corresponding term in the Thomson Reuters DealScan database is a package. For simplicity, in the text we use "loan" interchangeably with SNC credit. According to Ivashina and Scharfstein (2010), roughly $95 \%$ of loans in DealScan also appear in SNC. Sufi (2007) analyzes the structure of lending syndicates and finds that the median loan has 5 lenders, well above the cutoff for inclusion in SNC, and that the number of lenders increases with borrower and loan size and if the borrower is publicly traded.
} 
provoke creation of a new loan identifier. We re-code these cases as modifications to the original loan based on the simultaneous disappearance of an existing loan and appearance of a new loan with the same lead lender and borrower.

The syndicated lending market covered by SNC accounts for a large share of total lending volume in the U.S. economy. As shown in figure A.1, the full SNC universe contained $\$ 1.2$ trillion of loans drawn and $\$ 2.79$ trillion of loans drawn and unused commitments outstanding as of the end of 2007. ${ }^{5}$ For comparison, the Consolidated Reports of Condition and Income (Call Reports) contain $\$ 1.44$ trillion of commercial and industrial loans drawn and $\$ 2.37$ trillion of unused commitments not associated with real estate or credit cards from all U.S. commercial banks on that date. ${ }^{6}$ Thus, while our analysis does not directly apply to small loans or firms not included in the SNC data, the loans in SNC aggregate to a quantitatively large share of the U.S. corporate loan market. In the remainder of the paper we further exclude a small share of loans not listed as a term loan or credit line and loans to financial borrowers. ${ }^{7}$

\subsection{SNC Covenant Review Sample}

In 2006 SNC began collecting information on covenant compliance for a subset of loans covering about $1 / 3$ of the loan volume in the SNC universe. We refer to loans in this subset as the covenant review sample. For each loan in the covenant sample, SNC obtains information on covenant compliance throughout the year from loan documentation augmented by supervisory inquiries to the banks when information is missing or incomplete.

The SNC covenant sample offers important advantages for measuring covenant compliance over previous data sets constructed by starting from the DealScan database and either hand-collecting information on subsequent loan outcomes from public filings (Nini, Smith, and Sufi, 2009; Roberts

\footnotetext{
${ }^{5}$ The SNC review for year $t$ covers loan commitments as of December 31st of year $t-1$. Thus, while SNC press releases would refer to $\$ 1.2$ trillion outstanding and $\$ 2.79$ trillion committed in review year 2008 , these totals actually refer to loans as of December 31st of 2007.

${ }^{6}$ Besides the $\$ 20$ million threshold and syndication requirement for inclusion in the SNC data, totals in the Call Reports and SNC may differ because SNC includes the part of loans provided by non-bank lenders if they are part of a syndicate covered by SNC, because SNC may include some lending not classified as commercial and industrial in the Call Reports, and because the residual category for unused commitments in the Call Report data may contain non commercial and industrial loans. While these differences affect the levels, figure A.1 shows that the growth rates of aggregates in the two data sets track each other closely. As an alternative benchmark, in November 2012 the Federal Reserve Survey of Terms of Business Lending began reporting the fraction made under syndication of all origination volume of commercial and industrial loans made by commercial banks; averaged across all months from November 2012 through August 2016, this fraction is 47.5\%.

${ }^{7}$ Loans to bank borrowers $(<0.5 \%)$ and loans to non-bank financial borrowers (8\%) make up a small share of SNC and our results are robust to not excluding them.
} 
and Sufi, 2009b; Nini, Smith, and Sufi, 2012; Denis and Wang, 2014; Roberts, 2015; Freudenberg et al., 2015) or by matching to Compustat to track financial ratios encoded in covenants (Chava and Roberts, 2008; Falato and Liang, 2016). Relative to these data sets, SNC contains many more observations per year including a representative share of non-public borrowers, contains supervisory information on covenant compliance including when the breach results in a waiver, and contains information on the lender's response to the violation.

Table 1 reports summary statistics for the pre-crisis and crisis periods for the full SNC universe of term loans and credit lines to nonfinancial borrowers (columns 1 and 4), for the subset of these loans in the covenant sample (columns 2 and 5), and for those loans in the covenant sample for which we have a measure of the health of the lead lender (columns 3 and 6, described shortly). The covenant review sample over-weights non-investment grade and criticized credits. ${ }^{8}$ Nonetheless, it still contains a large share of credits with the highest ("Pass") rating, with $71 \%$ of loans in the review sample in the pre-crisis period and $47 \%$ in the crisis period receiving this designation. Furthermore, "special mention" loans, the highest category of non-passing loans and which consist of assets with potential weaknesses but which remain in good standing, account for about onehalf of the over-sampling of non-passing loans during the crisis period. The sample is otherwise representative of the SNC universe; loans in the covenant sample are of similar average size and maturity, exhibit a similar breakdown between term loans and credit lines, have similar utilization rates, and have similar propensities to get modified as those in the full universe. The sector composition of loans in the covenant sample is also similar to the SNC universe and broadly representative of the sectoral composition of the U.S. economy - more than one-quarter of loans are to firms in the services sector and roughly one-third are to firms in manufacturing or retail. The shares of loans attributed to each lead lender in the full SNC universe and SNC covenant sample are also similar, as shown in figure O.1 of the online appendix. In short, selection into the covenant review sample occurs along a single dimension, rating, which we observe for all loans in the SNC universe. We exploit this feature to re-weight the aggregation analysis in section 6 to be representative of the SNC universe.

\subsection{Maturity and Covenant Violation Frequency}

We now document two key facts using the SNC data.

\footnotetext{
${ }^{8}$ See e.g. https ://www.federalreserve.gov/newsevents/pressreleases/bcreg20110825a.htm.
} 
Table 1: Summary Statistics

\begin{tabular}{|c|c|c|c|c|c|c|}
\hline \multirow{5}{*}{ Sample: } & \multicolumn{3}{|c|}{ Pre-crisis (2006-07) } & \multicolumn{3}{|c|}{ Crisis (2008-09) } \\
\hline & \multirow{4}{*}{$\begin{array}{c}\text { Universe } \\
\text { (1) }\end{array}$} & \multirow{4}{*}{$\begin{array}{c}\text { Covenant } \\
\text { (2) }\end{array}$} & \multirow{3}{*}{$\begin{array}{l}\text { Lender- } \\
\text { covenant }\end{array}$} & \multirow{4}{*}{$\begin{array}{c}\text { Universe } \\
\text { (4) }\end{array}$} & \multirow{4}{*}{$\begin{array}{c}\text { Covenant } \\
\text { (5) }\end{array}$} & \multirow{4}{*}{$\begin{array}{l}\text { Lender- } \\
\text { covenant } \\
\quad(6)\end{array}$} \\
\hline & & & & & & \\
\hline & & & & & & \\
\hline & & & (3) & & & \\
\hline & \multicolumn{6}{|c|}{ Loans of any maturity } \\
\hline \multirow[t]{2}{*}{ Fraction $1+$ year remaining } & 0.91 & 0.92 & 0.92 & 0.88 & 0.88 & 0.89 \\
\hline & \multicolumn{6}{|c|}{ Loans with $1+$ year maturity remaining } \\
\hline \multicolumn{7}{|l|}{ Loan characteristics } \\
\hline Mean maturity (years) & 3.30 & 3.34 & 3.36 & 2.61 & 2.78 & 2.75 \\
\hline Fraction $2+$ years remaining & 0.85 & 0.88 & 0.89 & 0.74 & 0.79 & 0.79 \\
\hline Mean log total committed & 18.66 & 18.85 & 18.95 & 18.74 & 18.76 & 18.91 \\
\hline Fraction credit line & 0.61 & 0.59 & 0.60 & 0.51 & 0.49 & 0.49 \\
\hline Fraction Credit reduced & 0.27 & 0.26 & 0.26 & 0.37 & 0.38 & 0.38 \\
\hline Mean lead lender share & 0.19 & 0.14 & 0.15 & 0.18 & 0.14 & 0.14 \\
\hline Mean loan utilization rate & 0.53 & 0.56 & 0.55 & 0.61 & 0.64 & 0.63 \\
\hline \multicolumn{7}{|l|}{ Borrower characteristics } \\
\hline Fraction publicly-traded & 0.37 & 0.38 & 0.40 & 0.36 & 0.37 & 0.39 \\
\hline Mean log assets & & 12.58 & 12.76 & & 12.68 & 12.82 \\
\hline Mean leverage & & 0.49 & 0.49 & & 0.53 & 0.50 \\
\hline Fraction passing risk rating & 88.79 & 70.78 & 70.68 & 75.53 & 47.17 & 45.96 \\
\hline Fraction passing/special mention & 95.92 & 89.32 & 88.92 & 85.42 & 71.31 & 70.94 \\
\hline \multicolumn{7}{|l|}{ Covenant violation frequency } \\
\hline Bind $_{t}$ & & 0.25 & 0.24 & & 0.34 & 0.33 \\
\hline Bind $_{t}$, private borrowers & & 0.27 & 0.27 & & 0.36 & 0.34 \\
\hline $\operatorname{Bind}_{t}$, excluding waivers & & 0.09 & 0.08 & & 0.11 & 0.10 \\
\hline $\operatorname{Bind}_{t-1: t}$ & & 0.29 & 0.28 & & 0.39 & 0.37 \\
\hline Loan-year observations & 11,247 & 2,676 & 2,478 & 11,979 & 4,059 & 3,420 \\
\hline Unique borrowers & 4,769 & 1,309 & 1,166 & 4,992 & 1,704 & 1,409 \\
\hline Total committed $(\$ \operatorname{Tr})$ & 2.01 & 0.55 & 0.50 & 2.04 & 0.72 & 0.65 \\
\hline
\end{tabular}

Notes: The table reports summary statistics for the pre-crisis (2006-07) and crisis (2008-09) periods and for three samples. Columns with header "Universe" report summary statistics for the universe of credit lines and term loans to nonfinancial borrowers in the full SNC data set. Columns with header "Covenant" report summary statistics for the subset of these loans in the SNC covenant sample. Columns with header "Lender-covenant" report summary statistics for our final sample of all credit lines and term loans in the covenant sample to nonfinancial borrowers and where the lead lender is in the Chodorow-Reich (2014) lender health data set. Credit reduced equals 1 if either the loan is terminated before maturity or the loan commitment is reduced. Bind $_{t}$ and Bind $_{t-1: t}$ are indicator variables equal to 1 if a loan breached a covenant in the current or either the current or previous year, respectively. Total committed is the sum of loans outstanding and unused commitments averaged over the two year period. 
Fact 1: Bank credit has long maturity. The vast majority of bank loans are of long maturity. As shown in table 1, in both the full SNC data and the covenant sample roughly $90 \%$ of all loans and commitments outstanding at the end of 2007 had at least 1 year of maturity remaining. Conditional on a loan having a year maturity remaining, the mean remaining maturity at the end of 2007 was about 3.3 years. These numbers do not merely represent unusual maturity at the height of a boom. ${ }^{9}$ The long maturity of bank debt constricts the channels through which bank health can transmit to borrower outcomes.

Fact 2: Many loans breach covenants, especially in bad times. For each loan in the covenant sample, SNC reports a flag for whether the loan remained compliant throughout the year. If the loan remained compliant, SNC reports whether it would have been noncompliant but for a covenant waiver or reset granted by the lender. We consider a covenant to bind in either circumstance. This classification separates the event of breaching a covenant threshold from the subsequent resolution. Formally, we define the variable Bind $_{t}$ to equal 1 if a loan breaches any covenant threshold during year $t$.

Covenant violations occur routinely, and especially so during the financial crisis. As shown in table 1, roughly one-quarter of non-maturing loans in the SNC covenant sample breached a covenant during a typical year before the 2008-09 financial crisis. One-third of loans breached a covenant in each crisis year. This frequency exceeds by an order of magnitude the fraction of credit to nonfinancial firms that became delinquent. ${ }^{10}$ Such a high violation frequency makes the covenant channel potentially relevant to a wide swath of borrowers and quantitatively significant in its aggregate importance.

Because the macroeconomic importance of the covenant channel depends on the finding of a high violation frequency, it is important to validate this finding with respect to the full SNC

\footnotetext{
${ }^{9}$ For example, average maturity remaining in 2005 was also 3.3 years. Mian and Santos (2018) plot the distribution of maturity remaining for all SNC loans pooled over 1988-2010 and show a similar distribution. The maturity of loans in SNC also closely resembles the maturity structure of all long-term debt. Of firms in Compustat with positive long-term debt outstanding, the median amount due in less than one year is about $5 \%$ of the total and the 75 th percentile is less than 20\%. Across all firms in Compustat, the median firm has long-term debt maturing within a year of less than $0.2 \%$ of assets and the 75 th percentile firm has maturing debt of less than $2 \%$ of assets. These ratios are roughly the same in each of 2007, 2008, and 2009 and are based on all firms in the Compustat Annual file with non-negative revenue, assets, investment, or cash, with assets greater than each of cash, investment, and property, plant, and equipment, and with assets of at least $\$ 10$ million and asset growth lower than $200 \%$.

${ }^{10}$ According to Call Report data, the fraction of all commercial and industrial loans non-current on payments the main alternative event of default giving lenders the right to alter the terms of the loan - peaked during the 2007-09 episode in the third quarter of 2009 at 3.6\%. Expanding to corporate bond defaults, Moody's Default and Recovery Database reports corporate bond default rates of just over $4 \% 2008$ and roughly $2.5 \%$ in 2009 .
} 
universe and to explain why we obtain a higher violation frequency than previous studies. The higher violation frequency does not stem from attributes particular to the covenant sample. To make this point, we run the loan-level regression in the covenant sample:

$$
\begin{aligned}
\operatorname{Bind}_{l, b, f, t} & =\sum_{I} \beta_{1, I, t}[\text { Industry }=\mathrm{I}]_{f}+\beta_{2, t}[\text { Log committed }]_{l, t}+\beta_{3, t}[\text { Utilization }]_{l, t}+\beta_{4, t}[\text { Credit line }]_{l, t} \\
& +\sum_{P} \beta_{5, P, t}[\text { Loan purpose }=\mathrm{P}]_{l, t}+\sum_{R} \beta_{6, R, t}[\text { Loan rating }=\mathrm{R}]_{l, b, f, t}+e_{l, b, f, t}
\end{aligned}
$$

This regression projects $\operatorname{Bind}_{l, b, f, t}$, the indicator for loan $l$ from bank $b$ to firm $f$ violating a covenant in year $t$, on a set of variables observed in both the covenant sample and the full universe. These variables include borrower industry, loan size, loan utilization rate, loan type, loan purpose (working capital, general purpose, etc.), and the internal rating of the loan, each interacted with year. We then use the coefficients from equation (1) to impute Bind for the full SNC universe. This exercise re-weights the covenant sample using relevant features of the SNC universe, most importantly the loan rating which governs selection into the covenant review sample. The imputed fraction of covenant violations in the SNC universe is 0.23 pre-crisis and 0.30 in the crisis, very close to the values for the covenant sample.

It is instructive to compare to two prominent earlier approaches to determine why the violation frequency in SNC exceeds that reported in previous studies. Dichev and Skinner (2002), Chava and Roberts (2008), and Falato and Liang (2016) use Compustat to follow current ratio and net worth covenants reported at inception in DealScan. Dichev and Skinner (2002) report that roughly $30 \%$ of loans violate one of these covenants at some point during the life of the loan. However, this approach mechanically understates the frequency of total violations because it considers only two types of covenants and contains measurement error due to covenant thresholds changing after the initial loan contract (Denis and Wang, 2014; Roberts, 2015). In an innovative approach, Roberts and Sufi (2009a), Nini, Smith, and Sufi (2009), and Nini, Smith, and Sufi (2012) scrape SEC 10-Q and 10-K filings of publicly-traded firms looking for phrases associated with violations. Roberts and Sufi (2009a) find just 1\% of firms rated A or above report a violation in a typical year, rising to $9 \%$ for B rated borrowers and 18\% for borrowers rated CCC or worse. Nini, Smith, and Sufi (2012) use an improved version of the text-scraping algorithm and find roughly $12 \%$ of all publicly-traded firms report a violation in each of 2006 and 2007. Yet, while their data cover all covenant types, SEC regulation S-X governing disclosure does not require firms to report violations if they obtain an amendment or waiver before the end of the reporting period. Indeed, while each year roughly 
$25 \%$ of loans in the SNC covenant sample breach a covenant during 2006 or 2007 , only $9 \%$ of loans breach a covenant and do not receive a waiver in the same year. ${ }^{11}$ Finally, both previous approaches necessarily cover only publicly-traded borrowers.

Following a violation, a lender may choose to waive or reset the covenant or may force repayment or restructuring of the loan. These options are not mutually exclusive; a waiver can come with conditions and does not necessarily mean that the violation gets resolved without adverse consequences to the borrower. In practice, the final resolution of a loan restructuring takes a few months to achieve. In what follows we therefore use as our main measure the variable $\operatorname{Bind}_{t-1: t}=\max \left\{\operatorname{Bind}_{t-1}, \operatorname{Bind}_{t}\right\}$, which equals 1 if a loan breached a covenant in either the current or previous year. ${ }^{12}$

\section{Causal Identification}

To causally assess whether lender health affects the resolution of covenant violations, we turn to variation in the cross-section of lenders. In the next section, we report regressions of the form:

$$
\begin{aligned}
Y_{l, b, f, t} & =\beta_{0}+\beta_{1}\left[\text { Bad Lender }_{b}\right]+\beta_{2}\left[\text { Bind }_{l, t-1: t}\right]+\beta_{3}\left[\text { Bad Lender }_{b} \times \text { Bind }_{l, t-1: t}\right] \\
& +\gamma^{\prime} X_{l, b, f, t}+\epsilon_{l, b, f, t}
\end{aligned}
$$

where $Y_{l, b, f, t}$ denotes an outcome in year $t \in\{2008,2009\}$ for loan $l$ to firm $f$ from lender $b$, Bad Lender measures the health of lender $b$, and $X_{l, b, f, t}$ includes any covariates.

\footnotetext{
${ }^{11}$ We can more directly assess the importance of waivers in explaining the different violation propensities between SNC and Nini, Smith, and Sufi (2012, hereafter NSS) by comparing firm-years that appear in both the NSS data set and the SNC covenant sample. In the 601 overlapping firm-years covering the period 2006-2008, the violation propensity in SNC is roughly double that in NSS, reflecting 140 firm-years in which SNC identifies either a covenant violation or a covenant waiver while according to the NSS data the firm made no mention of such a violation or waiver in a regulatory filing. (There are 26 firm-years in which NSS identify a violation and SNC does not. These reflect cases where a firm obtained a preemptive waiver, for example in anticipation of missing a filing deadline or taking a one-time charge-off on earnings, where a firm had multiple loans and violated a covenant on a loan not in the SNC sample, and a few cases where we could not identify from the SEC filing why the NSS procedure assigned a violation.) We are grateful to Amir Sufi for providing us with the Nini, Smith, and Sufi (2012) data set.

${ }^{12}$ Loans can contain cross-default provisions by which a covenant breach on one loan triggers technical default on another. We have experimented with defining $\operatorname{Bind}_{t-1: t}$ based on whether any loan to the borrower breaches a covenant with no meaningful changes in our loan-level analysis. Similarly, our results remain quantitatively similar if we use Bind $t_{t}$ as our main measure of a violation. Nini, Smith, and Sufi (2012) emphasize that covenant terms tighten following a violation with the possible implication that the likelihood of violating a covenant in 2009 depends on the 2008 health of the lender. The backward-looking two-year treatment window negates this problem because the value in 2009, $\operatorname{Bind}_{2008: 2009}$, equals 1 for any loan that violates a covenant in 2008 and in particular does not depend on the outcome of the violation.
} 
Section 4.1 describes the measurement of Bad Lender. We then present our empirical strategies. Section 4.2 discusses conditions under which OLS consistently identifies $\beta_{1}, \beta_{2}$, and $\beta_{3}$ and provides suggestive evidence of these conditions being satisfied in our sample, including ex ante balancing of observable characteristics of borrowers of healthier and of less healthy lenders. Section 4.3 details a regression-discontinuity refinement using a sub-sample of loans on either side of but close to a covenant threshold. Section 4.4 introduces the instrumental variables design and four excluded instruments that predict Bind.

\subsection{Lender Health Measures}

The 2008-09 period offers a useful laboratory for studying the transmission from banks to corporate borrowers because the origins of the financial distress lay outside the corporate sector. Rather, prominent explanations include the exposure of financial institutions to real estate markets and toxic assets, and counterparty risk and network proximity to failing institutions (see e.g. Ivashina and Scharfstein, 2010; Cornett et al., 2011; Erel, Nadauld, and Stulz, 2011; Fahlenbrach, Prilmeier, and Stulz, 2012; Santos, 2011). The variable Bad Lender combines measures of lender health, adopted from Chodorow-Reich (2014), that reflect these forces.

The first measure, originally proposed by Ivashina and Scharfstein (2010), identifies a bank's exposure to Lehman Brothers through the fraction of the bank's syndication portfolio in which Lehman Brothers had a lead role. This exposure affected banks directly through the syndicated market as firms with credit lines provided by Lehman Brothers drew down the remainder of their credit line as a precautionary measure following the Lehman bankruptcy, draining liquidity from the other syndicate members. The second lender health variable measures a bank's exposure to private-label mortgage-backed securities through the correlation of its daily stock return with the return on the ABX AAA 2006-H1 index in the fourth quarter of 2007. The ABX AAA 2006-H1 index follows the price of residential mortgage-backed securities issued during the second half of 2005 and with a AAA rating at issuance. The correlation indicates the market's perception of the bank's exposure to the mortgage crisis. The third measure is 2007-08 trading revenue as a share of assets, as most writedowns occurred on the trading book. We extract the first principal component of the three measures and create the rank-normalized variable Bad Lender as the rank of the first principal component divided by the number of lenders. The variable Bad Lender therefore lies on the unit interval with a value of 1 assigned to the lender in the worst health. 
Syndicated loans include a lead lender and participant lenders. The lead lender manages the servicing of the loan and typically provides the largest share of the funds. Most loan contracts require the agreement of lenders providing at least $51 \%$ of the commitment to accelerate repayment or modify loan terms following a covenant breach. ${ }^{13}$ Because the lead lender provides the largest share of the loan, plays an organizing role among syndicate members, and as the servicing agent has responsibility for carrying out any renegotiation, in our main results we assign lender health on the basis of the lead lender only. Effectively, we assume the lead lender is always pivotal in resolving a covenant violation. Our main results are robust to alternative definitions of the health of the syndicate, as shown in section 5.5.

Following Chodorow-Reich (2014), we construct the health measures for the most active lead lenders in the syndicated lending market. After excluding lenders in the Chodorow-Reich (2014) data set without a publicly traded stock price (required to compute the ABX loading) or otherwise missing one of the key health variables, our final data set includes 34 lenders. ${ }^{14}$ As shown in columns (3) and (6) of table 1, more than $90 \%$ of the loan volume in the covenant sample comes from loans with lead lenders in our lender data set and these loans appear similar to the full covenant sample along all dimensions. Figure O.2 of the online appendix reports the distribution of lender health, weighted by the shares of each lender in SNC.

Figure 1 reports the time series of the shares of aggregate commitments from lenders in the top and bottom quartile of the lender health distribution. These shares are stable between 2005 and 2007, indicating that ex post distressed banks did not lend more aggressively ex ante. The share of commitments from lenders in the least healthy quartile falls sharply in 2008 and remains depressed in 2009, before stabilizing in 2010 and 2011. In section 6, we quantify how much of the difference in lending behavior in 2008 and 2009 is attributable to the differential response to covenant violations of healthier and less healthy lenders.

\footnotetext{
${ }^{13}$ For example, the credit agreement described in section 2 defines the "Required Lenders" in Section 8.02(b) as "(i) Lenders having Revolving Exposures and unused Revolving Commitments representing not less than 51\% of the sum of the total Revolving Exposures and unused Revolving Commitments at such time and (ii) in any event not less than two Lenders. (p.15)" Unlike in DealScan where many loans list multiple lead arrangers, the SNC supervisors always identify a single lead arranger as the servicing agent.

${ }^{14}$ The lender health measures from Chodorow-Reich (2014) are available at http://scholar.harvard.edu/ files/chodorow-reich/files/final_bank_variables.xlsx. About one-quarter of the lenders in the ChodorowReich (2014) data set are foreign-owned or otherwise not under the regulatory purview of the SNC supervisors. Nonetheless, SNC captures many loans from these lenders because the syndicate participants include multiple supervised lenders, as is the case with the loan described in section 2 .
} 
Figure 1: Aggregate Lending by Quartile of Bank Health

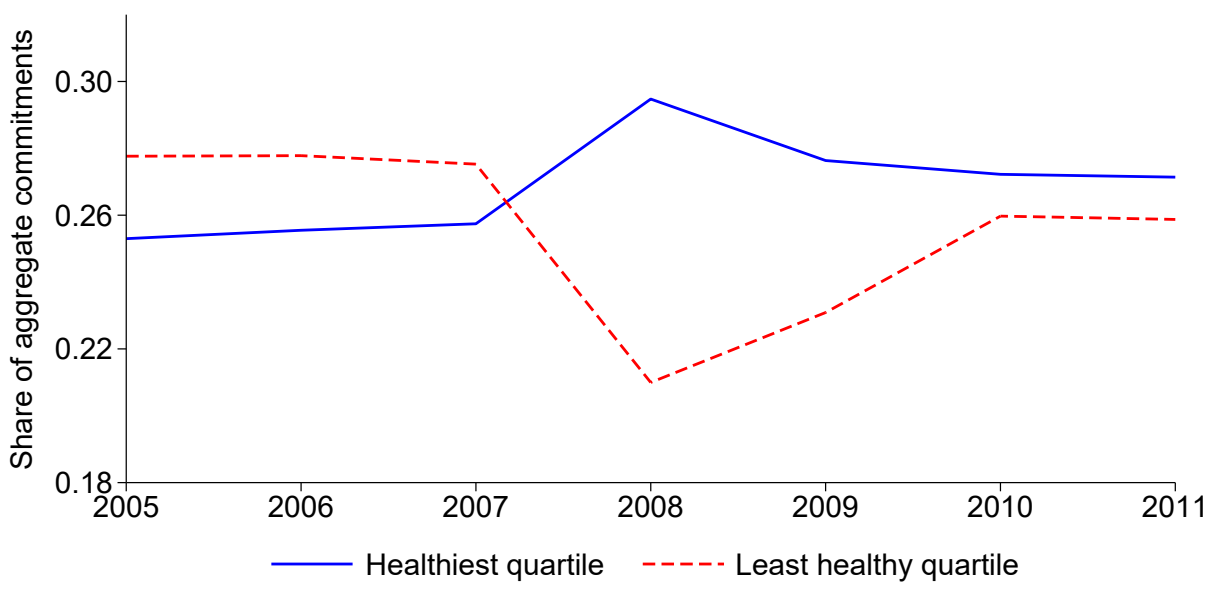

Notes: The figure reports the share of total commitments from lead lenders in the top and bottom quartile of the lender health distribution. The quartiles are constructed by weighting banks by the value of their commitments.

\subsection{OLS}

Estimating equation (2) with ordinary least squares (OLS) raises two main concerns. First, firms that violate covenants and have unhealthy lenders may differ along other dimensions from firms that violate covenants and have healthier lenders. Second, violation of a covenant correlates with other firm characteristics and loan outcomes may also depend on the interplay of lender health and these other characteristics.

We start by presenting evidence that borrowers of healthier and less healthy lenders in fact look similar along numerous observable dimensions, including within the subset of firms that violate covenants. Such balancing is consistent with "as good as random" matching of borrowers and lenders at origination. "As good as random" does not preclude any matching of borrowers and lenders along even unobservable dimensions. Rather, because our bank health measures capture exposure to largely unforeseen shocks during the crisis such as the losses in MBS markets and the collapse of Lehman Brothers, it requires that any such matching not correlate with lenders' exposure to these tail events. ${ }^{15}$

The origin of the 2008-09 crisis outside of the corporate loan sector makes "as good as ran-

\footnotetext{
${ }^{15}$ Notably, financial markets before the crisis, as embodied in credit default swaps, did not predict the subsequent distress in the banking sector. Schwert (2018) finds evidence that bank-dependent borrowers (those without a credit rating) are more likely to borrow from better-capitalized banks. This sorting affects our results only insofar as better capitalized banks also avoided MBS exposure and did not cosyndicate with Lehman Brothers. In this case, such a correlation would bias against our empirical results. We also control extensively for borrower-level characteristics below; in particular, our main results change minimally if we control for whether a borrower is bank-dependent.
} 
dom" assignment a priori plausible. Supporting this assumption, Chodorow-Reich (2014) reports similarity of borrowers of healthier and less healthy lenders along observable characteristics such as the employment decline in the borrower's industry and county and balancing along unobserved characteristics using a specification with borrower fixed effects. Columns (1)-(3) of table 2 provide further evidence of balancing of borrower and loan characteristics by quantile of lender health. ${ }^{16}$ Panel A uses variables drawn from SNC and restricts to non-expiring loans. Borrowers of lenders below and above the median of crisis lender health had statistically indistinguishable mean assets, leverage, supervisory risk rating, and remaining maturity on their loans at the start of the crisis. Panel B restricts the sample to borrowers in Compustat and shows balancing on additional measures of financial health from those data, including on cash flow, profitability, Tobin's Q, market beta, and volatility.

Even if matching at origination occurred as good as randomly, covenant violators of unhealthy lenders may still be different. Of particular concern, ex post distressed lenders may have offered looser covenants ex ante, and borrowers of unhealthy lenders may have worked harder to avoid violating covenants in expectation of worse treatment. If active, these mechanisms would make OLS an inconsistent estimator. Contra this concern, table 2 shows that loans from lenders in good and bad health had economically and statistically similar covenant tightness before the crisis (Panel A, row 1, columns (1)-(3)) and exhibited similar propensities to violate a covenant during the crisis (Panel C, columns (1)-(3)). ${ }^{17}$ These results provide evidence against ex post distressed lenders having offered looser covenants ex ante or of many borrowers of distressed lenders successfully manipulating the covenant threshold to avoid violating. Columns (4)-(6) provide additional evidence by demonstrating balancing of borrower and loan characteristics within the subset of violators. Violators who had borrowed from healthier and less healthy lenders

\footnotetext{
${ }^{16}$ Online table O.1 reports balancing along the same variables as in table 2 but in a regression setting with a continuous measure of lender health.

${ }^{17}$ Covenant tightness refers to the percent distance from threshold of the most tightly binding covenant. We obtain this variable from text fields accompanying the SNC covenant sample. These text fields do not have a uniform layout, reducing the sample for this variable. We have also confirmed the similarity of ex ante covenant tightness using data from DealScan covering the last general purpose or working capital loan issued to each nonfinancial borrower before the crisis. For this analysis, we follow Bradley and Roberts (2015) and define covenant restrictiveness using the number of covenants in the loan package and BerlinNiniYu in excluding observations with no covenants reported as these appear to reflect missing data rather than an actual absence of covenants. The mean number of covenants in the DealScan sample is 2.3 with a standard deviation of 1.0 . The difference in the number of covenants in loans from a lead lender in the top and bottom half of the lender health distribution is an economically trivial 0.12 (t-statistic 1.03). Finally, a Kolmogorov-Smirnov test does not reject equality of the full distributions of pre-crisis covenant tightness from healthy and less healthy lenders.
} 
Table 2: Balancing



Variable mean:

Covenant tightness

1.72

Panel A: SNC pre-crisis variables

Log assets

12.72

5.74

0.50

12.81

0.23

Leverage

70.04

0.49

1.17

10.98

11.11

0.35

Risk rating

71.51

1.21

0.54

0.53

0.93

Maturity remaining

3.34

0.56

42.20

44.69

0.93

Observations

1,215

1.12

2.66

2.69

0.36

1,263

2,478

358

335

693

Panel B: Compustat pre-crisis variables

Cash flow/assets (\%)

4.86

4.89

0.04

0.58

0.41

0.08

ROA (\%)

10.22

10.49

0.30

8.66

9.41

0.63

Tobin's Q

1.52

1.43

0.90

1.36

1.29

0.45

Z-score

0.16

0.09

1.09

0.08

0.06

0.52

Disc. accruals/assets (\%)

$-0.35$

$-1.16$

0.53

$-1.66$

$-1.75$

0.36

S\&P credit rating (\%)

76.75

74.60

0.63

76.56

78.78

0.30

Bankruptcy or delisting

5.67

6.85

1.18

7.81

8.09

0.26

Market beta

3.65

3.77

$-0.12$

3.46

3.39

0.07

Idiosyncratic volatility

12.62

12.76

0.46

13.03

12.63

0.76

Total volatility

21.99

21.77

1.02

22.25

22.21

0.11

Observations

450

469

919

124

133

257

$100 \times$ Bind $_{t-1: t}$

Observations
37.96

1,673
Panel $C: S N C$ crisis variables

$36.59 \quad 0.82$

$1,747 \quad 3,420$

Notes: The table reports selected summary statistics by lender health. "Healthier lenders" are those for which Bad Lender <median and "Less healthy lenders" are those for which Bad Lender >median, where Bad Lender is the rank of the lead lender's health normalized to lie on the unit interval, with a value of 1 corresponding to the least healthy lender. 
appear similar in size, pre-crisis leverage, risk rating, maturity remaining, and along the financial characteristics drawn from Compustat. We cannot reject equality of means for any variable.

The second concern with OLS is that covenant violation status is not randomly assigned. Comparing columns (1) and (2) to columns (3) and (4) of table 2, borrowers that violate covenants during the crisis were ex ante riskier, more levered, less profitable, more volatile, already closer to a violation threshold, and had lower cash flows. These differences raise the possibility that unhealthy lenders prioritized negotiations to reduce exposure to all weak firms, and not only to those that violated covenants. The long-term nature of contracts should have limited lenders' ability to tighten credit to non-violators, mitigating the plausibility of this alternative interpretation. To further address this possibility, our baseline specification includes as covariates measures of borrower quality interacted with lender health, which isolate the impact of lender health $\times$ violation from the impact of lender health $\times$ borrower quality.

\subsection{Near Violation Threshold Sample}

The preceding sub-section argued that OLS may in fact provide consistent estimates in our setting. Nonetheless, we present two additional research designs that further relax the assumptions embedded in the OLS approach. The first restricts the sample to loans on either side of but close to a covenant threshold. This approach follows an influential literature using regression discontinuity methods to study the impact of covenant violations on firms (Chava and Roberts, 2008; Roberts and Sufi, 2009a; Nini, Smith, and Sufi, 2012; Falato and Liang, 2016). The logic is that even if borrowers of less healthy lenders were of worse quality or worked harder to manipulate violation status than borrowers of healthier lenders, as long as manipulation is not precise, then status is randomly assigned in a neighborhood around the threshold (Lee and Lemieux, 2010). In support of this assumption, McCrary (2008) density tests do not reject the null of continuous density of distance to violation in either the full sample $(\mathrm{p}$-value $=0.75)$ or in the subsample of loans from lenders in the worse half of the lender health distribution ( $p$-value=0.46). Absence of precise manipulation is sufficient to causally identify treatment effects for borrowers of healthy and less healthy lenders separately, as we show formally in Online Appendix O.2. It follows that the interaction term Bad Lender $\times$ Bind in equation (2) identifies the additional effect of a violation

in the set of loans from less healthy lenders, even if the overall distribution of borrowers or of covenant violators differs across lender type. 


\subsection{Instrumental Variables}

Our final research design treats Bind as an endogenous variable and introduces four excluded instruments (and their interactions with Bad Lender) that predict Bind and Bad Lender $\times$ Bind but should not otherwise affect the dependent variable $Y$. We describe the instruments and then show first stage results.

The first two instruments affect the travel time between the headquarters of the lead lender and the borrower. Similar to Giroud (2013) and Bernstein, Giroud, and Townsend (2016), we expect reduced travel time to increase the monitoring ability of a bank. In our setting, this would lessen the need for restrictive covenants, making it less likely the borrower violates during the 2008-09 crisis. We follow these articles and use as our first excluded instrument the introduction in the year of loan origination of a new airline route (direct or indirect) that reduces the air travel time between the lead lender's and borrower's headquarters counties. The second instrument is an indicator for whether an airline that services the primary route connecting the lender's and borrower's counties is in bankruptcy proceedings during the year of origination. Both of these events are strong predictors of the minimum travel time between two cities. The main threat to the exclusion restriction is that the opening of an airline route anticipates growth of the origin or destination and that an airline bankruptcy reflects declining conditions in these cities. The fact that large national airlines account for all of the airline bankruptcies in the sample mitigates the second concern. We also follow Giroud (2013) in reporting robustness exercises that include lender and borrower location fixed effects to address the possibility that new airline routes anticipate growth of the origin or destination city.

The third instrument is an indicator for whether a bank has a strict or lax supervisor at the time of origination. As in Agarwal et al. (2014), we find that some supervisors systematically impose stricter or laxer lending standards. ${ }^{18}$ We expect stricter regulators to demand tighter covenants, increasing the likelihood of a violation during the crisis. Importantly for the exclusion restriction, having a lax supervisor at the time of origination does not correlate with Bad Lender during the crisis (see table O.2).

The fourth instrument captures a random cash flow shock. Brown, Gustafson, and Ivanov

\footnotetext{
${ }^{18}$ The main supervisor is one of the Federal Reserve Board of Governors, FDIC, OCC, or a state regulator. We are prevented from disclosing the assignment of strict or lax to each supervisor. However, our attribution methodology is consistent with Agarwal et al. (2014).
} 
Table 3: First Stage

\begin{tabular}{|c|c|c|c|c|}
\hline \multirow[t]{2}{*}{ Dependent variable: } & \multicolumn{4}{|c|}{ Bind } \\
\hline & $(1)$ & $(2)$ & $(3)$ & $(4)$ \\
\hline New Route & $\begin{array}{c}-7.7^{* * *} \\
(2.6)\end{array}$ & & & $\begin{array}{c}-11.4^{* * *} \\
(4.0)\end{array}$ \\
\hline Airline Bankruptcy & $\begin{array}{l}13.9^{\text {*** }} \\
(2.4)\end{array}$ & & & $\begin{array}{l}9.8^{* *} \\
(4.5)\end{array}$ \\
\hline Lax Supervisor & & $\begin{array}{c}-6.8^{* * *} \\
(2.3)\end{array}$ & & $\begin{array}{c}-11.9^{* *} \\
(4.8)\end{array}$ \\
\hline Abnormal Snow & & & $\begin{array}{l}10.6^{* * *} \\
(1.6)\end{array}$ & $\begin{array}{c}22.3^{* *} \\
(6.6)\end{array}$ \\
\hline Controls & Yes & Yes & Yes & Yes \\
\hline Partial F-statistic & 19.4 & 9.0 & 42.5 & 28.1 \\
\hline Observations & 3,420 & 3,420 & 3,420 & 3,420 \\
\hline
\end{tabular}

Notes: The table reports the first stage regressions for endogenous variable Bind. The sample consists of all loans in the SNC covenant sample at the start of 2008 or 2009 with at least one year maturity remaining and a lead lender in the lender health data set. Bind is an indicator variable equal to 1 if a borrower violated a covenant in either the current or previous year. Controls: year, industry, log assets, leverage, risk rating, the interaction of each with Bad Lender, and loan purpose and loan type. Standard errors two-way clustered by borrower and lead lender reported in parentheses. ${ }^{*}, * * * *$ indicate significance at the 10,5 , and 1 percent levels, respectively.

(forthcoming) show that abnormally high snow fall in a firm's location results in temporarily higher costs and lower earnings. Since most financial covenants depend on earnings, we expect higher abnormal snow fall to predict covenant violations. Our measure is the level of snow fall in the winter quarters (Q1 and Q4) of the year relative to the ten year trailing average. Importantly, firms that violate covenants because of extreme weather events should not differ along other dimensions that would affect how lenders resolve the violation. For ease of interpretation, we rank-normalize this variable to lie on the unit interval.

Columns (1) to (3) of table 3 report the first stage results for Bind, separately for the two travel time instruments, the lax supervisor indicator, and abnormal snow cover. We also include in each regression our baseline set of covariates: year and industry fixed effects, borrower size, leverage, and risk rating, loan purpose and type, and the interaction of each borrower covariate with Bad Lender. Each excluded instrument predicts Bind with the expected sign and has strong explanatory power, with partial F-statistics ranging between 9 and 43. The instruments also generate meaningful economic variation in Bind; a new airline route reduces the likelihood of a covenant binding by 7.7 p.p., an airline bankruptcy increases the likelihood by 13.9 p.p., a lax supervisor reduces the likelihood by 6.8 p.p., and moving from the 25 th to the 75 th percentile of abnormal snow fall 
increases the violation propensity by 5.3 p.p. Column (4) groups all of the instruments together. Each coefficient retains its expected sign and remains highly statistically significant, indicating substantial independent predictive power of each instrument. The joint F-statistic of 28 signifies a strong first stage. To provide some context for the exclusion restriction, table O.2 of the online appendix reports placebo first stage results replacing Bind with Bad Lender as the dependent variable. The exclusion restriction requires that the excluded instruments affect outcomes only through their effect on Bind; in particular, they should not affect Bad Lender. Individually or jointly, the excluded instruments have no statistical power for predicting Bad Lender and the confidence intervals rule out economically meaningful effects.

\section{Empirical Results}

We present empirical results at the borrower and loan level. Section 5.1 displays our main finding non-parametrically by comparing the average change in loan commitment by cells of covenant compliance and lender health. Section 5.2 analyzes linear probability models for whether a loan undergoes a reduction in committed amount. Section 5.3 measures the change in total credit at the loan and borrower level and reveals that affected borrowers do not substitute toward other sources of credit. Section 5.4 shows that the covenant channel transmits to balance sheet and real outcomes such as investment and employment. Section 5.5 reports robustness and specification tests to bolster the causal interpretation of the results. Finally, section 5.6 explores treatment heterogeneity by loan characteristics.

\subsection{Non-parametric Evidence}

Table 4 displays a non-parametric version of our main result by comparing the average change in loan commitment by quartile of lender health and whether the loan breached a covenant. To focus on seemingly insulated borrowers, we restrict to loans with at least one year maturity remaining. Because of the rarity of loans with shorter maturity, imposing this sample restriction has a negligible effect, and we report the corresponding table including expiring credit in table O.3. Among loans that do not breach a covenant, the average change in commitment is small, positive, and does not differ much by lender health. These changes reflect the frequent renegotiation of loan terms even absent a covenant violation (Roberts and Sufi, 2009b; Denis and Wang, 2014; 
Table 4: Non-parametric Evidence

\begin{tabular}{lccc}
\hline \hline & \multicolumn{2}{c}{$\% \Delta$ Total committed } & \\
\cline { 2 - 3 } & Bind $_{t-1: t}=0$ & Bind $_{t-1: t}=1$ & Difference \\
\hline \multirow{2}{*}{ Lender health quartile: } & & & \\
Quartile 1 (healthiest lenders) & 0.004 & -0.065 & -0.069 \\
Quartile 2 & {$[\mathrm{N}=529]$} & {$[\mathrm{N}=319]$} & \\
& 0.024 & -0.074 & -0.098 \\
Quartile 3 & {$[\mathrm{N}=517]$} & {$[\mathrm{N}=343]$} & \\
& 0.039 & -0.131 & -0.172 \\
Quartile 4 (least healthy lenders) & {$[\mathrm{N}=507]$} & {$[\mathrm{N}=351]$} & \\
& 0.044 & -0.156 & -0.200 \\
Difference Q4-Q1 & {$[\mathrm{N}=489]$} & {$[\mathrm{N}=365]$} & \\
& 0.040 & -0.091 & -0.131 \\
\hline \hline
\end{tabular}

Notes: The table reports the average change in loan commitment in each cell. The sample consists of all loans in the SNC covenant sample at the start of 2008 or 2009, with at least one year maturity remaining, and with a lead lender in the lender health data set. Bad Lender is the rank of the lead lender's health normalized to lie on the unit interval, with a value of 1 corresponding to the least healthy lender. Bind is an indicator variable equal to 1 if a borrower violated a covenant in either the current or previous year. The brackets report the number of observations in each cell.

Roberts, 2015; Mian and Santos, 2018). In contrast, loans that violate a covenant experience large average reductions in credit, rising from an average decline of $6.5 \%$ in the healthiest quartile of lenders to a decline of $15.6 \%$ in the least healthy quartile. Thus, changes in credit on existing loans concentrated on covenant violators, and more so for loans from less healthy lenders. The additional 13.1 percentage point reduction in credit for loans that violate covenants and come from lenders in the least healthy relative to the healthiest quartile is a non-parametric differencein-difference estimate of the effect of having a lender in bad health following a covenant violation.

\subsection{Probability of Credit Reduction}

We now turn to regression analysis in order to quantify statistical significance, control for covariates, and employ our alternative identification strategies. We start with linear probability models of how lender health affects credit availability following a covenant violation. The outcome variable, Credit reduced, equals 1 if either the loan is terminated before maturity or the loan commitment is reduced. The structure of SNC allows us to follow a loan through amendments, modifications, and refinancing in constructing this variable. Standard errors are two-way clustered 
by borrower and lead lender. ${ }^{19}$

Table 5 reports results using equation (2). For readability, all coefficients are multiplied by 100 . The first column imposes $\beta_{3}=0$, i.e. no interaction of Bad Lender and Bind, controls only for year and industry fixed effects, and restrict to loans with at least one year maturity remaining in order to focus on seemingly insulated borrowers. In this specification, both un-interacted variables have positive and significant coefficients. Column (2) adds the interaction term Bad lender $\times$ Bind. The coefficients on the main effects fall substantially and become statistically insignificant upon addition of the interaction term. Recalling the normalization of the lender health measure to lie on the unit interval, the coefficient on the interaction of 25.9 has the interpretation that moving from a lender at the 25th percentile of the lender health distribution to a lender at the 75th percentile raises the likelihood of a reduction in credit following a violation by $25.9 / 2=12.9$ percentage points. This difference is statistically significant at the $1 \%$ level.

In column (3) we additionally control for borrower size, leverage, and risk rating, and loan purpose and type, and the interaction of each borrower covariate with Bad Lender. Including these control variables allows borrowers of healthier and less healthy lenders to differ along observable dimensions and for weaker lenders to reduce credit by more to all weak borrowers and not just to covenant violators. While the explanatory power of the regression rises with the controls, the magnitude and statistical significance of the interaction coefficient remains stable. ${ }^{20}$ The coefficient stability with and without the controls is consistent with the ex ante matching of borrowers and lenders and covenant tightness being as good as randomly assigned. ${ }^{21}$

The results so far apply only to long-term loans in order to focus on seemingly-insulated

\footnotetext{
${ }^{19}$ We cluster along the lead lender dimension because the treatment Bad Lender does not vary across loans from the same lead lender. The borrower dimension accounts for borrowers with multiple loans in the sample each with a different lead lender. The sample contains relatively few such borrowers and the standard errors are virtually unchanged if we cluster by lead lender only.

${ }^{20}$ These control variables all come from SNC, so that their inclusion does not diminish the sample size. Table O.4 in the online appendix reports robustness to additional controls including financial variables available only in Compustat.

${ }^{21}$ Not shown, the coefficients on the interaction of Bad Lender and borrower quality are all not statistically significant and close to zero, providing further evidence against unhealthy lenders having reduced credit to all low quality borrowers irrespective of violation status. The statistically insignificant estimate of $\beta_{1}$ also merits brief comment. Borrowers attached to bad lenders but who did not violate a covenant did not experience a significantly higher likelihood of having their credit diminished. This result militates against a correlated decline in loan demand and voluntary reduction of credit across all borrowers of less healthy lenders as an explanation for why these banks reduced lending. We also find in unreported regressions based on merging the SNC data with loan pricing information in DealScan an increase in interest costs for covenant violators of unhealthy lenders, a result again inconsistent with a voluntary reduction in loan amount. Finally, the probability of a waiver is substantially lower for loans from less healthy lenders.
} 
Table 5: OLS Estimates of Loan Commitment Terminated or Reduced

\begin{tabular}{|c|c|c|c|c|c|c|}
\hline \multirow[t]{2}{*}{ Dependent variable: } & \multicolumn{4}{|c|}{ Credit reduced } & \multirow{2}{*}{$\frac{\text { Term. }}{(5)}$} & \multirow{2}{*}{$\begin{array}{c}\text { Intensive } \\
\text { margin } \\
(6)\end{array}$} \\
\hline & (1) & $(2)$ & $(3)$ & $(4)$ & & \\
\hline Bad Lender & $\begin{array}{c}8.8^{* *} \\
(4.4)\end{array}$ & $\begin{array}{c}-3.8 \\
(5.9)\end{array}$ & $\begin{array}{c}5.8 \\
(12.1)\end{array}$ & $\begin{array}{c}0.5 \\
(10.3)\end{array}$ & $\begin{array}{c}1.5 \\
(5.0)\end{array}$ & $\begin{array}{c}4.3 \\
(13.6)\end{array}$ \\
\hline Bind & $\begin{array}{l}14.1^{* * *} \\
(2.3)\end{array}$ & $\begin{array}{c}4.3 \\
(3.1)\end{array}$ & $\begin{array}{c}5.6^{* *} \\
(2.7)\end{array}$ & $\begin{array}{l}6.4^{* *} \\
(2.6)\end{array}$ & $\begin{array}{c}0.7 \\
(3.3)\end{array}$ & $\begin{array}{c}4.9 \\
(3.1)\end{array}$ \\
\hline Bad Lender $\times$ Bind & & $\begin{array}{c}25.9^{* * *} \\
(6.7)\end{array}$ & $\begin{array}{l}22.9^{* * *} \\
(6.7)\end{array}$ & $\begin{array}{l}17.6^{* *} \\
(6.7)\end{array}$ & $\begin{array}{l}10.9^{* *} \\
(5.4)\end{array}$ & $\begin{array}{l}12.0^{* *} \\
(5.2)\end{array}$ \\
\hline Estimator & OLS & OLS & OLS & OLS & OLS & OLS \\
\hline Year, Industry FE & Yes & Yes & Yes & Yes & Yes & Yes \\
\hline Borrower, loan controls & No & No & Yes & Yes & Yes & Yes \\
\hline Controls $\times$ Bad Lender & No & No & Yes & Yes & Yes & Yes \\
\hline Include expiring loans & No & No & No & Yes & No & No \\
\hline$R^{2}$ & 0.080 & 0.081 & 0.116 & 0.114 & 0.107 & 0.100 \\
\hline Observations & 3,420 & 3,420 & 3,420 & 3,843 & 3,420 & 3,420 \\
\hline
\end{tabular}

Notes: The table reports linear probability model regressions of the form: $Y_{l, b, f, t}=\beta_{0}+\beta_{1}[$ Bad Lender $]+$ $\beta_{2}[$ Bind $]+\beta_{3}[$ Bad Lender $\times$ Bind $]+\gamma^{\prime} X_{l, b, t}+\epsilon_{l, b, f, t}$. The sample consists of all loans in the SNC covenant sample at the start of 2008 or 2009 and a lead lender in the lender health data set. The variable Credit reduced equals 1 if either the loan is terminated before maturity (Term.) or the loan commitment is reduced (Intensive margin). Bad Lender is the rank of the lead lender's health normalized to lie on the unit interval, with a value of 1 corresponding to the least healthy lender. Bind is an indicator variable equal to 1 if a borrower violated a covenant in either the current or previous year. Reported coefficients are multiplied by 100. Borrower controls: log assets, leverage, risk rating. Loan controls: loan purpose, loan type. Standard errors two-way clustered by borrower and lead lender reported in parentheses. ${ }^{*}, * *, * * *$ indicate significance at the 10,5 , and 1 percent levels, respectively.

borrowers. In this sample, unhealthy lenders can force a reduction in exposure only on covenant violators. In column (4), we expand the sample to expiring loans. ${ }^{22}$ We continue to find an economically and statistically significant interaction term. Perhaps more surprising, the main effect on Bad Lender remains small and statistically insignificant, despite lenders' contractual freedom to reduce credit on expiring loans. This result obtains because, as shown in table 1, very little credit is actually short-term. Thus, this column illustrates our main conclusion: differences in financial health across banks mattered through their effect on the resolution of covenant violations.

Columns (5) and (6) return to the sample of long-term loans and split the dependent variable into outright terminations and intensive margin reductions in credit. By construction, the coefficients in these columns sum to the coefficients reported in column (3) for the combined variable

\footnotetext{
${ }^{22}$ Recall that we re-code all new loans from the same lead lender to the same borrower to have the same loan ID as a simultaneously expiring loan. Therefore, for expiring loans the dependent variable in column (4) captures the change in credit from the expiring loan's lead lender to the borrower.
} 
Table 6: Alternative Estimates of Loan Commitment Terminated or Reduced

\begin{tabular}{lccccc}
\hline \hline Dependent variable: & \multicolumn{5}{c}{ Credit reduced } \\
\cline { 2 - 6 } & $(1)$ & $(2)$ & $(3)$ & $(4)$ & $(5)$ \\
\hline & & & & & \\
Bad Lender & 11.1 & 5.3 & 5.2 & 1.3 & 6.8 \\
& $(10.4)$ & $(5.2)$ & $(3.9)$ & $(2.9)$ & $(8.5)$ \\
Bind & 6.7 & 2.1 & 7.8 & 0.6 & 6.2 \\
& $(4.3)$ & $(13.8)$ & $(15.5)$ & $(17.4)$ & $(7.9)$ \\
Bad Lender $\times$ Bind & $23.0^{* *}$ & $31.5^{* *}$ & $22.8^{* * *}$ & $38.0^{* *}$ & $36.4^{* * *}$ \\
& $(11.0)$ & $(15.2)$ & $(4.7)$ & $(18.2)$ & $(12.5)$ \\
\hline Estimator & OLS & IV & IV & IV & IV \\
Excluded instrument & & Travel & Supervisor & Snow & All \\
Close violator sample & Yes & No & No & No & No \\
Year, Industry FE & Yes & Yes & Yes & Yes & Yes \\
Borrower, loan controls & Yes & Yes & Yes & Yes & Yes \\
Controls $\times$ Bad Lender & Yes & Yes & Yes & Yes & Yes \\
Distance control & Yes & No & No & No & No \\
Observations & 780 & 3,420 & 3,420 & 3,420 & 3,420 \\
\hline \hline
\end{tabular}

Notes: The table reports linear probability model regressions of the form: $Y_{l, b, f, t}=\beta_{0}+\beta_{1}[$ Bad Lender $]+$ $\beta_{2}[$ Bind $]+\beta_{3}[$ Bad Lender $\times$ Bind $]+\gamma^{\prime} X_{l, b, t}+\epsilon_{l, b, f, t}$. The sample consists of all loans in the SNC covenant sample at the start of 2008 or 2009 with at least one year maturity remaining and a lead lender in the lender health data set. In column (1), the sample is additionally restricted to loans for which the distance to the closest covenant threshold is less than $30 \%$. The variable Credit reduced equals 1 if either the loan is terminated before maturity or the loan commitment is reduced. Bad Lender is the rank of the lead lender's health normalized to lie on the unit interval, with a value of 1 corresponding to the least healthy lender. Bind is an indicator variable equal to 1 if a borrower violated a covenant in either the current or previous year. Reported coefficients are multiplied by 100. Borrower controls: log assets, leverage, risk rating. Loan controls: loan purpose, loan type. Standard errors two-way clustered by borrower and lead lender reported in parentheses. ${ }^{*}, * * * * *$ indicate significance at the 10,5 , and 1 percent levels, respectively.

Credit reduced. The higher likelihood of a reduction in credit for a covenant violator with an unhealthy lender comes roughly half from a higher likelihood of an outright termination and roughly half from a higher likelihood of an intensive margin reduction in credit.

Table 6 repeats the analysis using our alternative estimation strategies. Columns (1) implements a regression discontinuity (RD) approach. Specifically, we add as control variables the percent distance from the threshold of the most tightly binding covenant at the start of the year and the interaction of this variable with Bad Lender and we exclude observations for which the absolute value of the distance control exceeds $30 \% .{ }^{23}$ The interaction coefficient of 23.0 is little

\footnotetext{
${ }^{23}$ While the flag for covenant compliance covers the entire year, we have the distance measure only at the start and end of the year. For firms that breach a threshold, distance at the end of the year obviously depends on the response of the lender and would not constitute a valid control. We have the distance measure for 1,717 of the 3,420 observations in the full sample.
} 
changed from the full-sample OLS coefficient of 22.9 reported in column (3) of table 5. Table O.5 of the online appendix reports robustness of this result to higher order polynomials in distance and to a smaller bandwidth around the violation threshold.

Columns (2)-(5) report the IV specifications. We obtain similar second stage coefficients using the travel time (column 2), lax supervisor (column 3), or abnormal snow (column 4) instruments (as well as their interaction with Bad Lender) separately. The similarity and statistical significance of the interaction term across instrument sets bolsters the credibility of the instruments, as they capture very different sources of variation in Bind. Grouping all of the excluded instruments together in column (5), we obtain similar coefficients on the main effects and a slightly larger interaction coefficient than with OLS. Not shown in the table, the J-statistic cannot reject joint exogeneity of the excluded instruments (p-value 0.18). Table O.6 of the online appendix reports additional robustness of the IV estimators, including (i) controlling for borrower and lender location in the specification with the travel time instrument, as in Giroud (2013); (ii) controlling for lender fixed effects in the specification with the supervisor strictness instrument, which restricts the variation to coming from changes in a lender's supervising institution arising from the periodic rotation of supervisors, as in Agarwal et al. (2014); (iii) controlling for borrower location fixed effects in the specification with the abnormal snow instrument to account for time-invariant characteristics of borrowers' locations; and (iv) controlling for borrower location and lender fixed effects in the specification combining all excluded instruments together. ${ }^{24}$ For example, the interaction coefficient becomes 27.6 (standard error 9.7) in the specification with all excluded instruments and including borrower location and lender fixed effects, while the coefficient on Bind remains small and insignificant.

\subsection{Effect on Credit Available and Substitution}

We now examine the effect on total credit available to the borrower including the ability to switch to other lenders. Panel A of table 7 reports OLS results using the full covenant review sample, Panel B restricts to loans within $30 \%$ of a covenant violation threshold and controls for the distance to threshold, and Panel C reports IV results grouping all of the excluded instruments

\footnotetext{
${ }^{24}$ Note that including lender fixed effects necessitates removing the main effect on Bad Lender from the specification. The interpretation of the coefficient on Bad Lender as the effect of lender health on firms that do not violate covenants explains why we include it instead of lender fixed effects in our baseline specification. Likewise, identification of the robustness specifications with borrower county fixed effects comes only from counties with multiple borrowers.
} 
together. All panels and columns include the full set of controls shown in table 5.

Column (1) reports estimates of equation (2) where the dependent variable is the percent change in the total amount committed and the sample contains only loans that began the year with remaining maturity greater than one year and remain extant at the end of the year. Thus, this column shows the intensive margin change in credit at the loan level. ${ }^{25}$ The interaction coefficient of -16.4 in Panel A has the interpretation that a covenant violation results in an intensive margin decline $16.4 / 2=8.2$ percentage points larger when moving from a lender at the 25 th percentile of the lender health distribution to a lender at the 75th percentile. The decline is larger in Panels B and $\mathrm{C}$, although the confidence intervals overlap.

Column (2) adds to the sample loans that began the year with maturity greater than one year but are prematurely terminated. Thus, column (2) captures the intensive and extensive margins of adjustment. Including loan terminations causes the interaction coefficient to rise by about twothirds in absolute value relative to the specification including only the intensive margin. Across these two columns and similar to the results in table 5 , the much smaller coefficients on the main effects for Bad Lender and Bind reflect the insulation of borrowers with long-term loan contracts who do not violate a covenant from the health of their lender in the case of Bad Lender and the pervasiveness of covenant waivers granted by lenders in good health in the case of Bind.

Figure 2 illustrates graphically the result from column (2) in the near-violator sample. The figure shows two separate plots. The left panel contains only loans from lenders in the less healthy half of the distribution. These loans have been partitioned into 20 equally-spaced bins based on the distance to a covenant violation at the start of the year, with loans to the left of zero already in violation and loans to the right of zero not in violation. ${ }^{26}$ Each dot shows the average change in commitment for loans in a bin and represents 19.5 loans on average (780 loans in the near-violator sample divided by 40 total bins). The solid lines report local linear regressions and the dashed lines $95 \%$ confidence bands. There is a visible jump down in credit growth for loans in violation at the start of the year. The right panel contains the same plot but for loans from lenders in the healthier half of the health distribution. For this sample, there is no discernible jump for loans in violation at the start of the year. The difference in the size of the jumps provides the

\footnotetext{
${ }^{25}$ For this specification only, the sample also excludes loans that receive a new loan identifier in SNC but that we re-code as a continuous loan based on continuity of the borrower-lender pair.

${ }^{26}$ Of course, loans that start the year in compliance may breach a covenant during the year. In this sense, the figure reports the reduced form of a fuzzy regression discontinuity.
} 


\begin{tabular}{|c|c|c|c|c|c|}
\hline \multirow[t]{3}{*}{ Dependent variable: } & \multicolumn{3}{|c|}{$\% \Delta$ Total committed } & \multirow{2}{*}{$\frac{\Delta \text { Utilization }}{\text { Borrower }}$} & \multirow{2}{*}{$\begin{array}{c}\% \Delta \\
\text { Drawn } \\
\text { Borrower }\end{array}$} \\
\hline & $\begin{array}{c}\text { Loan } \\
\text { intensive } \\
\text { margin }\end{array}$ & $\begin{array}{c}\text { Loan } \\
\text { all } \\
\text { margins }\end{array}$ & Borrower & & \\
\hline & $(1)$ & $(2)$ & $(3)$ & $(4)$ & $(5)$ \\
\hline & \multicolumn{5}{|c|}{ Panel A: full sample OLS } \\
\hline Bad Lender & $\begin{array}{c}-0.9 \\
(3.3)\end{array}$ & $\begin{array}{c}6.3 \\
(14.0)\end{array}$ & $\begin{array}{c}6.2 \\
(13.4)\end{array}$ & $\begin{array}{c}0.3 \\
(5.7)\end{array}$ & $\begin{array}{c}7.4 \\
(6.9)\end{array}$ \\
\hline Bind & $\begin{array}{l}-1.0 \\
(1.3)\end{array}$ & $\begin{array}{c}-8.5^{* *} \\
(3.7)\end{array}$ & $\begin{array}{c}-6.3^{* *} \\
(3.1)\end{array}$ & $\begin{array}{l}-1.5 \\
(2.6)\end{array}$ & $\begin{array}{c}2.3 \\
(3.1)\end{array}$ \\
\hline Bad Lender $\times$ Bind & $\begin{array}{c}-16.4^{* * *} \\
(3.3)\end{array}$ & $\begin{array}{c}-24.4^{* * *} \\
(14.0)\end{array}$ & $\begin{array}{c}-30.1^{* * *} \\
(10.3)\end{array}$ & $\begin{array}{l}7.3^{* * *} \\
(1.5)\end{array}$ & $\begin{array}{c}-19.1^{* *} \\
(8.0)\end{array}$ \\
\hline & \multicolumn{5}{|c|}{ Panel B: near violation threshold OLS } \\
\hline Bad Lender & $\begin{array}{c}5.4 \\
(10.0)\end{array}$ & $\begin{array}{c}1.8 \\
(12.5)\end{array}$ & $\begin{array}{l}-1.9 \\
(18.7)\end{array}$ & $\begin{array}{c}3.7 \\
(4.8)\end{array}$ & $\begin{array}{c}8.0 \\
(10.1)\end{array}$ \\
\hline Bind & $\begin{array}{c}-5.1 \\
(4.5)\end{array}$ & $\begin{array}{r}-10.3 \\
(7.1)\end{array}$ & $\begin{array}{c}-7.8 \\
(7.6)\end{array}$ & $\begin{array}{l}-2.8 \\
(8.4)\end{array}$ & $\begin{array}{c}8.6 \\
(5.2)\end{array}$ \\
\hline Bad Lender $\times$ Bind & $\begin{array}{c}-24.6^{* * *} \\
(8.3)\end{array}$ & $\begin{array}{c}-34.8^{* * *} \\
(11.3)\end{array}$ & $\begin{array}{c}-35.1^{* *} \\
(17.7)\end{array}$ & $\begin{array}{l}10.3^{* *} \\
(4.5)\end{array}$ & $\begin{array}{c}-34.8^{* *} \\
(14.5)\end{array}$ \\
\hline & \multicolumn{5}{|c|}{ Panel $C$ : full sample IV } \\
\hline Bad Lender & $\begin{array}{c}1.8 \\
(5.1)\end{array}$ & $\begin{array}{c}0.5 \\
(19.3)\end{array}$ & $\begin{array}{c}8.9 \\
(13.8)\end{array}$ & $\begin{array}{c}1.6 \\
(2.4)\end{array}$ & $\begin{array}{c}1.4 \\
(8.7)\end{array}$ \\
\hline Bind & $\begin{array}{r}-1.7 \\
(3.5)\end{array}$ & $\begin{array}{c}-7.3 \\
(6.2)\end{array}$ & $\begin{array}{l}-5.8 \\
(4.9)\end{array}$ & $\begin{array}{l}-1.9 \\
(2.5)\end{array}$ & $\begin{array}{c}2.3 \\
(5.8)\end{array}$ \\
\hline Bad Lender $\times$ Bind & $\begin{array}{c}-19.2^{* * *} \\
(5.1)\end{array}$ & $\begin{array}{c}-31.4^{* * *} \\
(7.5)\end{array}$ & $\begin{array}{c}-37.6^{* * *} \\
(7.7)\end{array}$ & $\begin{array}{l}9.4^{* *} \\
(3.9)\end{array}$ & $\begin{array}{c}-24.1^{\text {*** }} \\
(5.7)\end{array}$ \\
\hline Year, Industry FE & Yes & Yes & Yes & Yes & Yes \\
\hline Borrower controls & Yes & Yes & Yes & Yes & Yes \\
\hline Loan controls & Yes & Yes & No & No & No \\
\hline Distance control & Panel B & Panel B & Panel B & Panel B & Panel B \\
\hline Controls $\times$ Bad Lender & Yes & Yes & Yes & Yes & Yes \\
\hline Panels A\&C observations & 2,289 & 3,420 & 1,803 & 1,803 & 1,803 \\
\hline Panel B observations & 413 & 780 & 357 & 357 & 357 \\
\hline
\end{tabular}

Notes: The table reports regressions of the form: $Y=\beta_{0}+\beta_{1}[$ Bad Lender $]+\beta_{2}[$ Bind $]+\beta_{3}[$ Bad Lender $\times$ Bind $]+$ $\gamma^{\prime} X+\epsilon$. Bad Lender is the rank of the lead lender's health normalized to lie on the unit interval, with a value of 1 corresponding to the least healthy lender. Bind is an indicator variable equal to 1 if a borrower violated a covenant in either the current or previous year. In column (1) the sample excludes loans that disappear or change identifier by the end of the year; in column (2) the sample is the same as table 5; and in columns (3)-(5) the sample contains all loans in the SNC universe to a borrower in the table 5 sample and the data are collapsed to the borrower-year level. The dependent variable is the percent change in total committed credit associated with loan $l(1)$; the percent change in total committed credit on loans from lead lender $b$ to borrower $f(2)$; the percent change in total committed credit aggregated across all loans in the SNC universe to borrower $f(3)$; the change in the utilization rate across all loans to borrower $f(4)$; or the percent change in total credit outstanding, defined as the sum of term loans and the drawn portion of credit lines, aggregated across all loans to borrower $f$ in the SNC universe (5). SNC Borrower controls: log assets, leverage, risk rating. Loan controls: loan purpose, loan type. Standard errors two-way clustered by borrower and lead lender (columns 1 and 2) or borrower and worst 
Figure 2: Committed Credit Around the Covenant Threshold

Less Healthy Lenders (Bad Lender > P50)

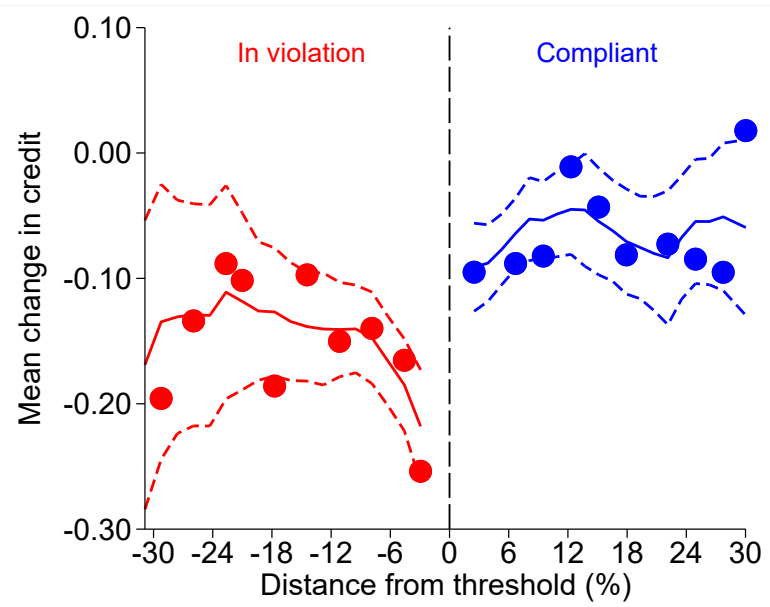

Healthier Lenders (Bad Lender < P50)

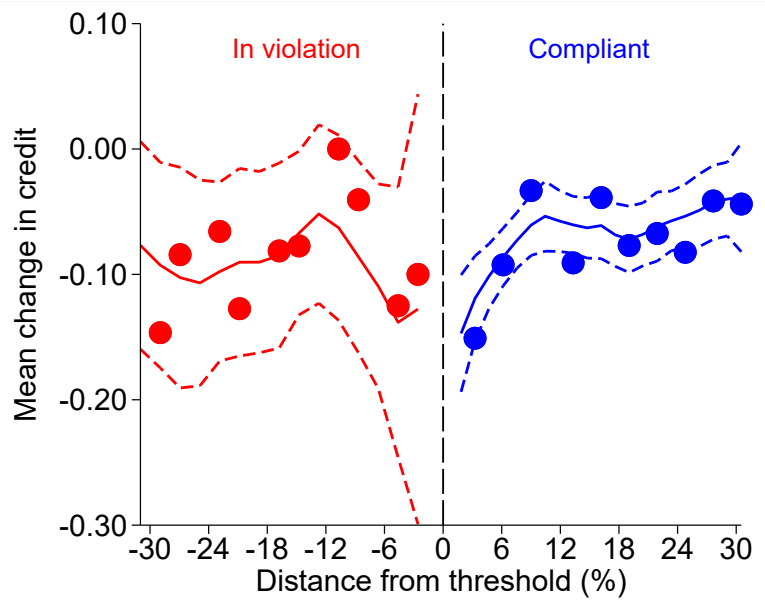

Notes: The figure plots the average annual growth in loan commitment against the distance from a covenant threshold at the start of the year, separately for loans from lenders with Bad Lender above the median (left panel) and below the median (right panel). The loans in each panel have been partitioned into 20 equally-spaced bins based on the distance to a covenant violation at the start of the year, with loans to the left of zero already in violation and loans to the right of zero not in violation. Each dot shows the average change in commitment for loans in a bin and represents 19.5 loans on average (780 loans in the near-violator sample divided by 40 total bins). The solid lines report a local polynomial of order 1 and the dashed lines $95 \%$ confidence bands based on bootstrapped standard errors.

above/below median version of the interaction term shown in column (2) of table 7 . The figure also illustrates the argument in appendix O.2 concerning causal identification in the near-violator sample; as long as manipulation around the violation threshold is not precise, status is randomly assigned in a neighborhood around the threshold (Lee and Lemieux, 2010) and the specification causally identifies treatment effects for borrowers of healthy and less healthy lenders separately.

Column (3) of table 7 aggregates to the borrower level. Here and elsewhere, when we aggregate to the borrower level we define both Bind and Bad Lender as the maximum across all loans for firms with multiple loans in the covenant sample. The dependent variable is the percent change in all loans to the borrower in the full SNC universe. Analyzing the effect on loan commitment at the borrower level allows for any substitution margin by borrowers toward lenders already servicing different loans or the opening of new loans. We find even larger percent declines in credit available after aggregating to the borrower level. Because the denominator of the dependent variable in column (3) includes all loan commitments to the borrower and therefore (weakly) exceeds the denominator in column (2), the larger interaction coefficient in column (3) indicates that affected 
borrowers receive less credit from other lenders. ${ }^{27}$ Previous literature has motivated costly switching to new lenders from asymmetric information between old and new lenders (Williamson, 1987; Sharpe, 1990; Hachem, 2011; Darmouni, 2016). An even simpler "covenant overhang" explanation may apply in the case of covenant violators-lenders do not want to provide new loans to a borrower with an unresolved covenant violation because of the uncertain resolution of that violation, and firms that have breached an interest coverage or debt covenant face a contractual prohibition on obtaining new lending.

Column (4) shows that firms respond to the decline in commitments in part by increasing their utilization rate. The higher utilization reinforces our causal interpretation that the decline in credit to these borrowers reflects a supply contraction and not a lower demand for borrowing by covenant violators of unhealthy lenders. Column (5) shows that there is nonetheless an overall decline in loans outstanding to the firm, defined as the sum of term loans and the drawn part of credit lines. Thus, the covenant channel not only reduces unused credit line commitments, but also affects on-balance sheet lending.

\subsection{Balance Sheet Adjustment and Real Outcomes}

We now turn in table 8 to how borrowers adjust to lower bank credit. Panel A reports results using the full covenant review sample, Panel B restricts to loans within $30 \%$ of a covenant violation threshold, and Panel C reports IV results grouping all of the excluded instruments together.

Columns (1) and (2) examine whether borrowers substitute non-bank credit. Column (1) uses the measure of total debt reported in SNC. This variable has the advantage of existing for all firms in SNC, including non-public firms, but the drawback that a firm must appear in SNC at the end of the year for us to observe the end-of-year value, so that the column (1) sample excludes borrowers whose loans were terminated. To isolate substitution toward non-SNC debt, we subtract from the total the sum of SNC term loans and the drawn part of credit lines and compute the difference between the beginning and end of the year as a percentage of beginning of period total assets. Column (2) studies the effect on debt issuance reported in Compustat. While the restriction to

\footnotetext{
${ }^{27}$ Recall that the SNC universe contains all loans of at least $\$ 20$ million shared by three or more unaffiliated financial institutions under the regulatory purview of one of the SNC supervisors. If borrowers substitute loans not in the SNC universe, then the result in column (3) could overstate the magnitude of the total bank credit decline. We have estimated a similar specification for the number of new loans reported by a borrower in DealScan, which does not condition on the identity of the lender, and also find a reduced likelihood of a new loan reported in DealScan for borrowers of unhealthy lenders who violate a covenant.
} 
Table 8: Financial and Real Adjustment

\begin{tabular}{|c|c|c|c|c|c|}
\hline \multirow[t]{2}{*}{ Dependent variable: } & $\begin{array}{c} \\
\text { Non-SNC } \\
\text { Debt/Assets } \\
\end{array}$ & $\begin{array}{c}\text { Bond } \\
\text { issuance/ } \\
\text { Assets } \\
\end{array}$ & $\begin{array}{c}\text { Payouts/ } \\
\text { Assets } \\
\end{array}$ & $\begin{array}{l}\text { Capex/ } \\
\text { Assets }\end{array}$ & $\begin{array}{l}\text { Employment } \\
\text { growth } \\
\end{array}$ \\
\hline & $(1)$ & $(2)$ & $(3)$ & $(4)$ & $(5)$ \\
\hline & \multicolumn{5}{|c|}{ Panel A: full sample OLS } \\
\hline \multirow[t]{2}{*}{ Bad Lender } & 9.0 & -1.7 & -5.6 & 5.2 & -2.4 \\
\hline & $(13.8)$ & $(2.7)$ & $(6.1)$ & $(3.4)$ & $(5.4)$ \\
\hline \multirow[t]{2}{*}{ Bind } & 6.6 & -0.9 & 0.9 & 0.2 & -0.2 \\
\hline & $(6.2)$ & $(1.2)$ & $(1.6)$ & $(0.4)$ & $(3.1)$ \\
\hline \multirow[t]{3}{*}{ Bad Lender $\times$ Bind } & 6.1 & 1.1 & $-4.5^{* *}$ & $-2.7^{* * *}$ & $-15.6^{* *}$ \\
\hline & $(14.7)$ & $(1.9)$ & $(2.3)$ & $(0.9)$ & $(5.9)$ \\
\hline & \multicolumn{5}{|c|}{ Panel B: near violation threshold OLS } \\
\hline \multirow[t]{2}{*}{ Bad Lender } & 1.3 & -1.9 & 6.4 & 8.3 & 3.3 \\
\hline & $(19.8)$ & $(12.0)$ & $(15.9)$ & $(8.5)$ & $(7.8)$ \\
\hline \multirow[t]{2}{*}{ Bind } & 5.3 & -4.8 & 2.4 & 0.5 & -3.1 \\
\hline & $(12.6)$ & $(5.9)$ & $(2.3)$ & $(0.8)$ & $(4.8)$ \\
\hline \multirow[t]{3}{*}{ Bad Lender $\times$ Bind } & -13.7 & 6.3 & $-14.1^{* *}$ & $-3.0^{*}$ & $-14.3^{* *}$ \\
\hline & $(21.2)$ & $(5.6)$ & $(6.7)$ & $(1.7)$ & $(6.7)$ \\
\hline & \multicolumn{5}{|c|}{ Panel $C$ : full sample IV } \\
\hline \multirow[t]{2}{*}{ Bad Lender } & 5.5 & -1.0 & -1.9 & -3.6 & -2.1 \\
\hline & $(8.3)$ & $(9.6)$ & $(5.1)$ & $(3.8)$ & $(3.5)$ \\
\hline \multirow[t]{2}{*}{ Bind } & 9.1 & 1.7 & 1.0 & 0.3 & -3.0 \\
\hline & $(7.6)$ & $(2.5)$ & $(3.1)$ & $(0.2)$ & $(8.8)$ \\
\hline \multirow[t]{2}{*}{ Bad Lender $\times$ Bind } & 8.2 & 3.4 & $-7.3^{* *}$ & $-5.2^{* *}$ & $-17.1^{* *}$ \\
\hline & $(13.3)$ & $(4.2)$ & $(3.1)$ & $(2.1)$ & $(7.5)$ \\
\hline Year, Industry FE & Yes & Yes & Yes & Yes & Yes \\
\hline Borrower controls & Yes & Yes & Yes & Yes & Yes \\
\hline Distance control & Panel B & Panel B & Panel B & Panel B & Panel B \\
\hline Controls $\times$ Bad Lender & Yes & Yes & Yes & Yes & Yes \\
\hline Dep. var. source & $\mathrm{SNC}$ & Compustat & Compustat & Compustat & Compustat \\
\hline Panels A\&C observations & 1,525 & 756 & 756 & 756 & 756 \\
\hline Panel B observations & 357 & 152 & 152 & 152 & 152 \\
\hline
\end{tabular}

Notes: The table reports regressions of the form: $Y=\beta_{0}+\beta_{1}[$ Bad Lender $]+\beta_{2}$ Bind $+\beta_{3}[$ Bad Lender $\times$ Bind $]+\gamma^{\prime} X+\epsilon$. In column (1) the sample contains all borrowers in the table 5 sample with at least one SNC loan outstanding at the end of the year and the data are collapsed to the borrower-year level. In columns (2)-(5) the sample is borrowers in the table 5 sample that also appear in Compustat and the data are collapsed to the borrower-year level. Bad Lender is the rank of the lead lender's health normalized to lie on the unit interval, with a value of 1 corresponding to the least healthy lender. Bind is an indicator variable equal to 1 if a borrower violated a covenant in either the current or previous year. The dependent variable is the change in non-SNC debt as a share of assets (1); bond issuance as a share of assets (2); shareholder payouts as as share of assets (3); capital expenditure as a share of book assets (4); or the log change in employment (5). The variables in columns (2)-(5) are winsorized at the $1 \%$ level. Borrower controls: $\log$ assets, leverage, risk rating. Standard errors two-way clustered by borrower and worst lead lender reported in parentheses. ${ }^{*}, * * * *$ indicate significance at the 10,5 , and 1 percent levels, respectively. 
firms in Compustat reduces the number of observations, it avoids the censoring problem of firms that exit SNC. ${ }^{28}$ We find no evidence of affected borrowers substituting toward non-SNC credit in either sample, likely for the same reasons that prevent substitution toward other lenders covered by SNC. Column (3) shows that firms also adjust by reducing shareholder payouts, again signaling scarcity of internal funds.

Columns (4) and (5) examine effects on real variables using the merged-Compustat sample. Previous research has found evidence of both lender health (e.g. Chodorow-Reich, 2014) and covenant violations (Chava and Roberts, 2008; Nini, Smith, and Sufi, 2012; Falato and Liang, 2016) negatively affecting firm investment and employment. We show that the interaction of these two variables matters above the main effects. For both investment and employment growth and across all research designs, the interaction term is statistically significant and the magnitude is such that essentially all of the negative impact of either Bad Lender or Bind on investment and employment goes through the interaction term and not through the main effects. These results provide direct evidence of the tight link between the the loan covenant channel and the financial accelerator in macroeconomic models such as Gertler and Kiyotaki (2010). ${ }^{29}$

\subsection{Robustness and Specification Tests}

This section reports a number of robustness and specification tests. To streamline presentation, we focus on the binary outcome specification of whether credit was reduced during the crisis and the full sample OLS specification. The online appendix reports additional robustness exercises where the outcome variable is the percent change in committed credit at the loan or borrower level.

Table 9 reports robustness to the measure of lender health. Column (1) reproduces the baseline regression from column (3) of table 5. Column (2) replaces the measure of lender health with the health of the pre-crisis lead lender, defined using loans outstanding in June 2007.30 Therefore,

\footnotetext{
${ }^{28}$ The merge uses company names and the string matching algorithm SAS SPEDIS. We manually review each proposed match for accuracy. The online appendix provides additional details on the merge procedure. We winsorize all Compustat variables at the $1 \%$ level.

${ }^{29}$ Subsequent to our paper circulating, Lian and Ma (2019) and Greenwald (2019) have also emphasized how covenants put cash-flow based lending at the heart of the financial accelerator mechanism.

${ }^{30}$ This date falls a few weeks before the implosion of the two Bear Stearns hedge funds marking the start of the subprime crisis, but at a point when few observers expected significant financial disruption. For example, the Federal Reserve meeting statement from June 28, 2007 acknowledges "ongoing adjustment in the housing sector" but expects the economy to expand "at a moderate pace over coming quarters" and sees the "risk that inflation will fail to moderate as expected" as the "predominant policy concern."
} 
it uses only information on borrower-lender matches made before lender health during the crisis became apparent. In practice, the stickiness of bank-borrower relationships makes lender health in June 2007 highly correlated with lender health at the start of 2008 or 2009 and we obtain very similar quantitative results using the June 2007 health variable.

Columns (3)-(6) demonstrate the robustness to including the health of syndicate participants, by using a commitment share-weighted mean (columns (3) and (4)) or median (columns (5) and (6)) of syndicate health. Recalling that the standard loan contract requires the agreement of lenders providing at least $51 \%$ of the commitment to accelerate repayment following a covenant breach, the weighted median assigns Bad Lender based on the health of the marginal lender required to build a coalition to renegotiate the loan. As a caveat, we lack a measure of the health of non-bank participants such as hedge funds, pension funds, or CLOs. However, while these non-bank participants provide $40 \%$ of the total commitment of the average loan, they typically play a relatively passive role in syndicate management. We assume they either follow the banks in the syndicate (columns (3) and (5)) or follow the direction of the lead (columns (4) and (6)) and impute a health measure for the non-banks accordingly. These specifications yield similar (and statistically significant) point estimates of the coefficient on Bad Lender $\times$ Bind, $\beta_{3}$, as the baseline coefficient in column (1). The larger standard errors for $\beta_{3}$ in columns (3)-(6), however, accord with our baseline assumption that lead lender health alone best captures the health of the pivotal member in resolving a covenant violation.

Columns (7)-(9) show results using the three measures of lender health separately, each ranknormalized. The largest absolute pairwise rank correlation across the measures is 0.36. Yet, using each lender health measure on its own gives similar results to the baseline coefficients.

Column (10) changes the dependent variable $Y_{l, b, f, t}$ to be the change in the lead lender's share of the loan commitment. If a decline in its health caused the lead lender to force a tightening of credit provision following a covenant violation, we should expect the lead lender's share of the renegotiated loan to decline on average. If instead the tightening of credit reflected only some unobservable attribute of the borrower, the lead lender share should remain constant or even increase due to enhanced agency problems between the lead and the other syndicate members. Notably, using the change in the lead's share as the dependent variable in equation (2) is akin to having bilateral credit to a borrower as the dependent variable but including a borrower-loan fixed effect. This specification therefore closely resembles the "within estimator" of Khwaja and Mian 
Table 9: Robustness to Lender Health Measure

\begin{tabular}{|c|c|c|c|c|c|c|c|c|c|c|}
\hline \multirow{3}{*}{$\begin{array}{l}\text { Dependent variable: } \\
\text { Lender health based on: }\end{array}$} & \multicolumn{9}{|c|}{ Credit reduced } & \multirow{3}{*}{$\begin{array}{c}\text { Change } \\
\text { in lead } \\
\text { share } \\
\text { Crisis } \\
\text { lead } \\
\frac{\text { (baseline) }}{(10)}\end{array}$} \\
\hline & \multirow{2}{*}{$\begin{array}{c}\begin{array}{c}\text { Crisis } \\
\text { lead } \\
\text { (baseline) }\end{array} \\
(1)\end{array}$} & \multirow{2}{*}{$\begin{array}{c}\text { June } \\
2007 \\
\text { lead } \\
(2)\end{array}$} & \multicolumn{2}{|c|}{$\begin{array}{l}\text { Crisis syndicate- } \\
\text { weighted mean }\end{array}$} & \multicolumn{2}{|c|}{$\begin{array}{l}\text { Crisis syndicate- } \\
\text { weighted median }\end{array}$} & \multirow{2}{*}{$\begin{array}{c}\begin{array}{c}\text { Crisis } \\
\text { lead } \\
(\text { Lehman })\end{array} \\
(7)\end{array}$} & $\begin{array}{l}\text { Crisis } \\
\text { lead } \\
(\mathrm{ABX})\end{array}$ & \multirow{2}{*}{$\begin{array}{c}\begin{array}{c}\text { Crisis } \\
\text { lead } \\
\text { (trading) }\end{array} \\
\frac{(9)}{}\end{array}$} & \\
\hline & & & $(3)$ & $(4)$ & $(5)$ & $(6)$ & & $(8)$ & & \\
\hline Bad Lender & $\begin{array}{c}5.8 \\
(12.1)\end{array}$ & $\begin{array}{r}-3.6 \\
(4.7)\end{array}$ & $\begin{array}{r}-12.5 \\
(8.3)\end{array}$ & $\begin{array}{c}-5.1 \\
(8.3)\end{array}$ & $\begin{array}{r}-10.5 \\
(6.8)\end{array}$ & $\begin{array}{l}-7.1 \\
(6.2)\end{array}$ & $\begin{array}{c}0.6 \\
(11.1)\end{array}$ & $\begin{array}{c}-10.9 \\
(12.5)\end{array}$ & $\begin{array}{r}-10.9 \\
(9.8)\end{array}$ & $\begin{array}{c}7.3 \\
(8.4)\end{array}$ \\
\hline Bind & $\begin{array}{l}5.6^{* *} \\
(2.7)\end{array}$ & $\begin{array}{l}7.6^{* *} \\
(3.3)\end{array}$ & $\begin{array}{l}-2.1 \\
(6.5)\end{array}$ & $\begin{array}{c}2.0 \\
(4.9)\end{array}$ & $\begin{array}{c}3.3 \\
(5.2)\end{array}$ & $\begin{array}{c}5.7 \\
(4.1)\end{array}$ & $\begin{array}{l}5.2^{* *} \\
(2.4)\end{array}$ & $\begin{array}{l}4.6^{* *} \\
(2.3)\end{array}$ & $\begin{array}{l}5.3^{* *} \\
(2.4)\end{array}$ & $\begin{array}{l}-4.3^{* *} \\
(2.0)\end{array}$ \\
\hline Bad Lender $\times$ Bind & $\begin{array}{l}22.9^{* * *} \\
(6.7) \\
\end{array}$ & $\begin{array}{l}24.9^{* * *} \\
(6.1)\end{array}$ & $\begin{array}{l}31.8^{* * *} \\
(11.9)\end{array}$ & $\begin{array}{l}26.7^{* * *} \\
(9.6)\end{array}$ & $\begin{array}{l}21.0^{* *} \\
(9.2) \\
\end{array}$ & $\begin{array}{l}19.2^{* *} \\
(7.8) \\
\end{array}$ & $\begin{array}{l}24.8^{* * *} \\
(6.0) \\
\end{array}$ & $\begin{array}{l}24.2^{* * *} \\
(5.0) \\
\end{array}$ & $\begin{array}{l}23.4^{* * *} \\
(5.5)\end{array}$ & $\begin{array}{c}-10.3^{* *} \\
(4.8) \\
\end{array}$ \\
\hline Impute non-bank using lead & n.a. & n.a. & No & Yes & No & Yes & n.a. & n.a. & n.a. & n.a. \\
\hline Year, Industry FE & Yes & Yes & Yes & Yes & Yes & Yes & Yes & Yes & Yes & Yes \\
\hline Borrower, Loan Controls & Yes & Yes & Yes & Yes & Yes & Yes & Yes & Yes & Yes & Yes \\
\hline Controls $\times$ Bad Lender & Yes & Yes & Yes & Yes & Yes & Yes & Yes & Yes & Yes & Yes \\
\hline Observations & 3,420 & 2,844 & 3,420 & 3,420 & 3,420 & 3,420 & 3,420 & 3,420 & 3,420 & 2,289 \\
\hline
\end{tabular}

Notes: The table reports linear probability model regressions of the form: $Y_{l, b, f, t}=\beta_{0}+\beta_{1}[$ Bad Lender $]+\beta_{2}[$ Bind $]+\beta_{3}[$ Bad Lender $\times$ Bind $]+\gamma^{\prime} X_{l, b, t}+\epsilon_{l, b, f, t}$, where Bad Lender is normalized to lie on the unit interval, with a value of 1 corresponding to the least healthy lender, and Bind is an indicator variable equal to 1 if a borrower violated a covenant in either the current or previous year. Column (1) reproduces column (3) of table 5. In column (2) the sample and variable definitions are the same as in column (1) except that the sample excludes loans to borrowers without a loan in SNC as of June 2007 and lender health assignment is based on the lead lender as of June 2007. In columns (3)-(6) the sample and variable definitions are the same as in column (1) except that lender health assignment is based on the weighted mean health of banks in the crisis syndicate (3), the weighted mean health of the crisis syndicate imputing the health of the lead for non-banks (4), the weighted median health of banks in the crisis syndicate (5), or the weighted median health of the crisis syndicate imputing the health of the lead for non-banks (6). In columns (7)-(9) the sample is the same as in column (1) but lender health is defined using only the Lehman exposure measure (7), the ABX exposure (8), or the trading revenue measure (9). In columns (1)-(9), the dependent variable Credit reduced equals 1 if either the loan is terminated before maturity or the loan commitment is reduced. In column (10) the sample excludes loans that disappear by the end of the year and the dependent variable is the change in the fraction of the loan commitment from the lead lender. Reported coefficients are multiplied by 100. Borrower controls: log assets, leverage, risk rating. Loan controls: loan purpose, loan type. Standard errors two-way clustered by borrower and lead lender reported in parentheses. ${ }^{*}, * *, * *$ indicate significance at the 10,5 , and 1 percent levels, respectively. 
(2008) in that it differences out any heterogeneity across borrowers in loan demand. The negative coefficient for the interaction term in column (10) indicates a reduction in lending by the lead lender relative to other syndicate participants, consistent with the tightening of credit reflecting the increase in internal cost of funds for the lead lender. The magnitude, a decline in commitment share of about 5 percentage points between lenders at the 25 th and 75 th percentiles of the lender health distribution, is equal to roughly one-third of the sample mean lead commitment share of $15 \%$ during the crisis reported in table 1 .

Table 10 and figure 3 demonstrate the stability of the results to changes in the sample. Column (1) of table 10 reproduces the baseline result. Columns (2)-(4) address the over-weighting of low quality loans in the covenant review sample, in column (2) by re-weighting the sample to match the distribution of risk ratings in the full SNC universe, in column (3) by including only loans with a pre-crisis rating of "Best", and in column (4) by excluding loans that violated a covenant before the crisis so that the sample only includes new violators. Column (5) only includes loans with at least 2 years maturity remaining. Column (6) excludes loans for which the lead lender does not retain any part of its share. Columns (7) and (8) expand the sample by merging into the full SNC data information on covenant compliance for loans not in the covenant review sample from Nini, Smith, and Sufi (2012) and from financial covenants reported in DealScan, respectively. The basic pattern remains similar across all of these specifications. 
Table 10: Sample Robustness

\begin{tabular}{|c|c|c|c|c|c|c|c|c|}
\hline \multirow{3}{*}{ Sample: } & \multicolumn{8}{|c|}{ Dependent variable: Credit reduced } \\
\hline & Baseline & $\begin{array}{c}\text { Re- } \\
\text { weighted }\end{array}$ & $\begin{array}{l}\text { Only } \\
\text { "Best" } \\
\text { rating }\end{array}$ & $\begin{array}{l}\text { Drop if } \\
\text { existing } \\
\text { violator }\end{array}$ & $\begin{array}{l}2+\text { years } \\
\text { maturity }\end{array}$ & $\begin{array}{l}\text { Drop if all } \\
\text { sold }\end{array}$ & Add NSS & $\begin{array}{c}\text { Add } \\
\text { DealScan }\end{array}$ \\
\hline & $(1)$ & $(2)$ & $(3)$ & $(4)$ & $(5)$ & $(6)$ & $(7)$ & $(8)$ \\
\hline Bad Lender & $\begin{array}{c}5.8 \\
(12.1)\end{array}$ & $\begin{array}{c}7.3 \\
(14.7)\end{array}$ & $\begin{array}{r}-4.7 \\
(9.9)\end{array}$ & $\begin{array}{c}7.6 \\
(16.5)\end{array}$ & $\begin{array}{l}-2.2 \\
(11.9)\end{array}$ & $\begin{array}{c}6.4 \\
(14.6)\end{array}$ & $\begin{array}{c}2.5 \\
(5.8)\end{array}$ & $\begin{array}{c}4.6 \\
(6.3)\end{array}$ \\
\hline Bind & $\begin{array}{c}5.6^{* *} \\
(2.7)\end{array}$ & $\begin{array}{r}4.7^{*} \\
(2.8)\end{array}$ & $\begin{array}{c}1.1 \\
(5.9)\end{array}$ & $\begin{array}{c}1.9 \\
(4.6)\end{array}$ & $\begin{array}{c}4.2 \\
(3.7)\end{array}$ & $\begin{array}{c}1.9 \\
(3.0)\end{array}$ & $\begin{array}{l}9.3^{* * *} \\
(2.8)\end{array}$ & $\begin{array}{l}6.6^{* *} \\
(2.8)\end{array}$ \\
\hline Bad Lender $\times$ Bind & $\begin{array}{l}22.9^{* * *} \\
(6.7)\end{array}$ & $\begin{array}{c}21.6^{* * *} \\
(6.1)\end{array}$ & $\begin{array}{c}24.4^{* *} \\
(9.8)\end{array}$ & $\begin{array}{l}29.8^{* * *} \\
(8.5)\end{array}$ & $\begin{array}{l}30.3^{* * *} \\
(7.3)\end{array}$ & $\begin{array}{l}29.7^{* * *} \\
(8.0)\end{array}$ & $\begin{array}{l}19.6^{* * *} \\
(6.8)\end{array}$ & $\begin{array}{l}18.8^{* * *} \\
(6.6)\end{array}$ \\
\hline Year, Industry FE & Yes & Yes & Yes & Yes & Yes & Yes & Yes & Yes \\
\hline Borrower, loan controls & Yes & Yes & Yes & Yes & Yes & Yes & Yes & Yes \\
\hline Controls $\times$ Bad Lender & Yes & Yes & Yes & Yes & Yes & Yes & Yes & Yes \\
\hline Observations & 3,420 & 3,420 & 1,572 & 2,735 & 2,702 & 2,805 & 4,765 & 5,005 \\
\hline
\end{tabular}

Notes: The table reports linear probability model regressions of the form: $Y_{l, b, f, t}=\beta_{0}+\beta_{1}[$ Bad Lender $]+\beta_{2}[$ Bind $]+\beta_{3}[$ Bad Lender $\times$ Bind $]+\gamma^{\prime} X_{l, b, t}+\epsilon_{l, b, f, t}$. Column (1) reproduces column (3) of table 5. Column (2) reweights the sample to match the distribution of risk ratings in the full SNC universe. Column (3) only includes loans with a pre-crisis rating of "Best". Column (4) excludes loans that violated a covenant before the crisis. Column (5) includes loans with less than 1 year maturity remaining. Column (6) only includes loans with at least 2 years maturity remaining. Column (7) excludes loans for which the lead lender does not retain any part of its share. Columns (8) and (9) expand the sample by including information on covenant compliance from Nini, Smith, and Sufi (2012) and from DealScan, respectively. The dependent variable Credit reduced equals 1 if either the loan is terminated before maturity or the loan commitment is reduced. Bad Lender is the rank of the lead lender's health normalized to lie on the unit interval, with a value of 1 corresponding to the least healthy lender. Bind is an indicator variable equal to 1 if a borrower violated a covenant in either the current or previous year. Reported coefficients are multiplied by 100. Borrower controls: log assets, leverage, risk rating. Loan controls: loan purpose, loan type. Standard errors two-way clustered by borrower and lead lender reported in parentheses. ${ }^{*}, * * * *$ indicate significance at the 10,5 , and 1 percent levels, respectively. 
Figure 3 reports the interaction coefficients and 95\% confidence intervals from re-estimating the baseline specification while excluding one lender at a time from the sample. ${ }^{31}$ The coefficients cluster tightly around the full sample estimate and the $95 \%$ intervals exclude zero in all subsamples. Thus, the covenant channel is not driven by the behavior of any single lender.

Table 11 reports placebo exercises. Columns (1) and (2) keep the measure of lender health assigned to each borrower the same as in our baseline specification but re-estimate the regressions from table 5 and table 7 for the likelihood and amount of a credit commitment reduction in 2006 and 2007. Borrowers of lenders in worse health during the crisis were not treated differently before the crisis upon violating a covenant. ${ }^{32}$ Column (3) replaces the variable Bind with an indicator for whether the borrower is in the first quartile of the size distribution. This specification shows that less healthy lenders did not simply cut credit to smaller borrowers irrespective of whether they violated a covenant. Column (4) follows Imbens and Lemieux (2008) and splits the sample of close violators into subsamples with Bind $=1$ and Bind $=0$, and for each subsample redefines Bind based on whether the variable Distance is above or below the median within the subsample. This specification shows that the jump in the likelihood of a credit reduction occurs only at the true threshold for violating a covenant.

\subsection{Heterogeneity}

The structure of loan contracts offers predictions for how the intensity of the treatment effect of having an unhealthy lender and violating a covenant may vary by type of borrower and loan. Table 12 explores this treatment heterogeneity. The table reports the coefficients $\beta_{3}$ and $\beta_{3, I}$ from the fully-interacted OLS regression:

$$
\begin{aligned}
Y_{l, b, f, t} & =\beta_{0}+\beta_{1}[\text { Bad Lender }]+\beta_{2}[\text { Bind }]+\beta_{3}[\text { Bad Lender } \times \text { Bind }]+\gamma^{\prime} X_{l, b, t} \\
& +\beta_{0, I}[I]+\beta_{1, I}[\text { Bad Lender } \times I]+\beta_{2, I}[\text { Bind } \times I]+\beta_{3, I}[\text { Bad Lender } \times \text { Bind } \times I] \\
& +\gamma_{I}^{\prime}\left[X_{l, b, t} \times I\right]+\epsilon_{l, b, f, t},
\end{aligned}
$$

\footnotetext{
${ }^{31}$ Due to disclosure limitations, we cannot report the identity of each lender. The lender identifiers labeling the $\mathrm{y}$-axis of the figure correspond to those shown in figures O.1 and O.2 of the online appendix, which show the concentration of lead lenders in SNC and lender health, respectively.

${ }^{32}$ In contrast, we find statistically significant evidence that having a covenant bind lowers credit unconditionally in the pre-crisis period. This result does not invalidate the placebo exercise. We would expect lenders to use covenant violations to restrict credit on some loans even outside the crisis. But this outcome should not occur differentially at lenders more impacted by the crisis, exactly as we find.
} 
Figure 3: Robustness to Dropping One Lender at a Time

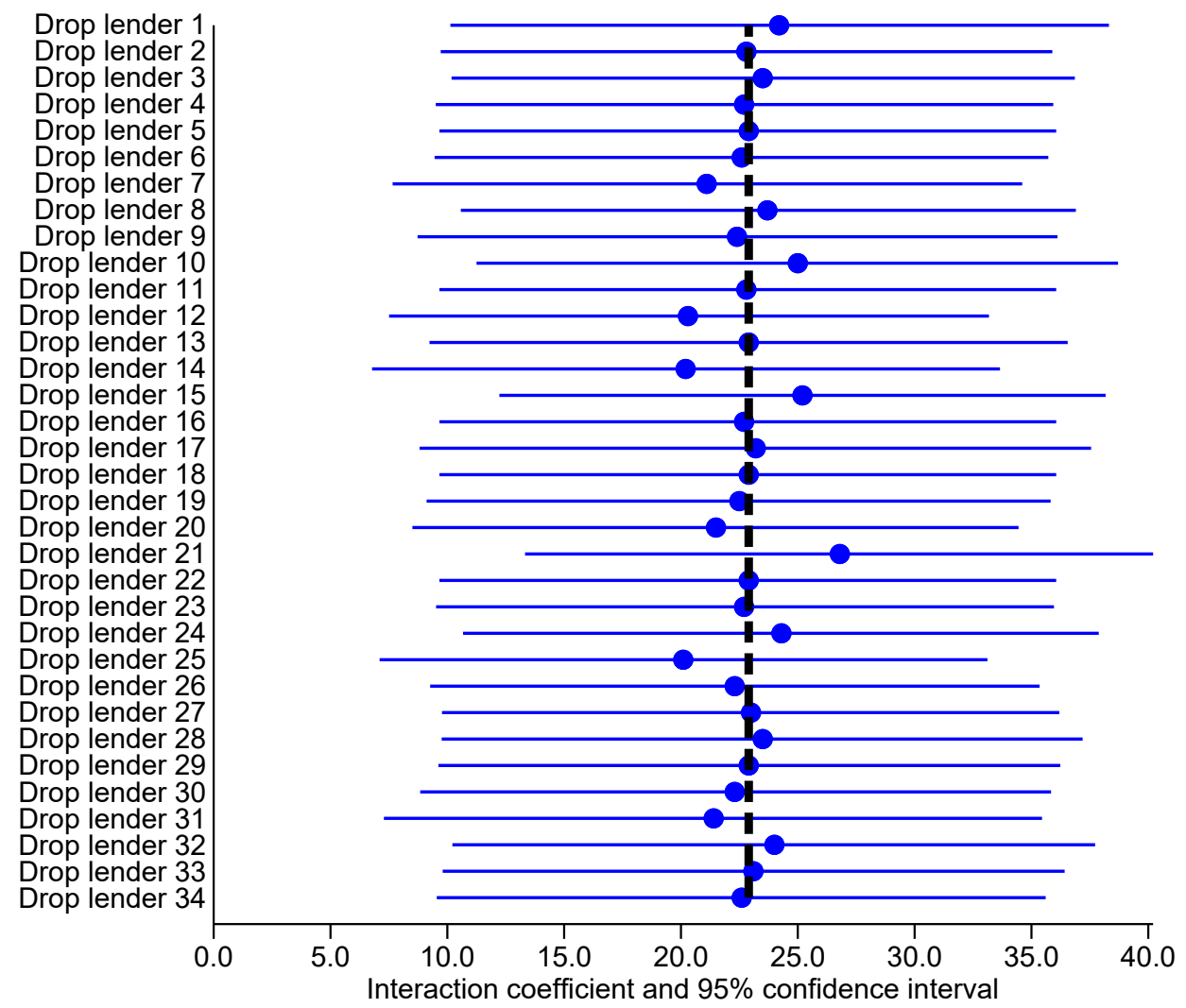

Notes: The figure reports the interaction coefficient (blue circle) and 95\% confidence interval (blue line) from repeating the specification shown in column (3) of table 5 while dropping one lender at a time from the sample. The dashed black line shows the value of the coefficient in the full sample.

where $Y_{l, b, f, t}$ is the variable Credit Reduced and $I$ is an indicator variable described in the table header. Thus, $\beta_{3}$ is numerically equivalent to the coefficient from a separate regression including only observations for which variable $I$ takes a value of 0 , while $\beta_{3}+\beta_{3, I}$ is numerically equivalent to the coefficient from a separate regression including only observations for which variable $I$ takes a value of 1 . The statistical significance of $\beta_{3, I}$ answers whether the data reject the null hypothesis of a homogeneous coefficient on $[$ Bad Lender $\times$ Bind $]$ in the two subsamples.

The first column of table 12 explores heterogeneity along the dimension of loan type. Because reducing the size of a term loan requires immediate repayment while reducing the limit on a credit line can impact only the unused portion of the commitment, the latter may have a less immediately drastic effect on borrowers. If so, lenders may more readily take action when the loan is a credit line than if it is a term loan. Column (1) shows that this heterogeneity holds in the data. While unhealthy lenders reduce credit to covenant violators with both term loans and credit lines, the 
Table 11: Placebo Specifications

\begin{tabular}{|c|c|c|c|c|}
\hline Placebo: & Pre-crisis & Pre-crisis & $\begin{array}{l}\text { Threshold: } \\
\text { size quartile }\end{array}$ & $\begin{array}{c}\text { Threshold: } \\
\text { shifted } \\
\text { tightness }\end{array}$ \\
\hline \multirow[t]{2}{*}{ Dependent variable: } & Credit reduced & $\begin{array}{l}\% \Delta \text { total } \\
\text { committed }\end{array}$ & Credit reduced & Credit reduced \\
\hline & $(1)$ & $(2)$ & $(3)$ & $(4)$ \\
\hline \multirow[t]{2}{*}{ Bad Lender } & -2.2 & 2.0 & -1.9 & $13.7^{*}$ \\
\hline & $(13.6)$ & $(14.3)$ & $(5.8)$ & $(8.0)$ \\
\hline \multirow[t]{2}{*}{ Bind } & $7.1^{* *}$ & $-16.2^{* *}$ & 3.3 & -1.7 \\
\hline & $(3.0)$ & $(7.7)$ & $(4.1)$ & $(6.9)$ \\
\hline \multirow[t]{2}{*}{ Bad Lender $\times$ Bind } & 8.3 & -4.8 & 1.0 & 2.3 \\
\hline & $(10.7)$ & $(17.6)$ & $(6.6)$ & 14.8 \\
\hline Year, Industry FE & Yes & Yes & Yes & Yes \\
\hline Borrower, Loan Controls & Yes & Yes & Yes & Yes \\
\hline Distance control & No & No & No & Yes \\
\hline Controls $\times$ Bad Lender & Yes & Yes & Yes & Yes \\
\hline Close violator sample & No & No & No & Yes \\
\hline Observations & 2,478 & 2,478 & 3,420 & 780 \\
\hline
\end{tabular}

Notes: The table reports regressions of the form: $Y_{l, b, f, t}=\beta_{0}+\beta_{1}[$ Bad Lender $]+\beta_{2}[$ Bind $]+\beta_{3}[$ Bad Lender $\times$ Bind $]+\gamma^{\prime} X_{l, b, t}+\epsilon_{l, b, f, t}$. In all columns, the variable Bad Lender is the rank of the crisis health of the assigned lender as of the period indicated in the table header normalized to lie on the unit interval, with a value of 1 corresponding to the least healthy lender. In columns (1) and (2) the sample consists of loans in the SNC covenant sample at the start of 2006 or 2007 with at least one year maturity remaining, the dependent variable is based on outcomes in 2006 and 2007, and lender health assignment is based on the lead lender at the start of the crisis. In column (3), Bind is replaced with an indicator for whether the borrower is in the bottom quartile of the size distribution. In column (4), Bind is replaced with an indicator for whether Distance is below the median on each side of the covenant threshold. Reported coefficients are multiplied by 100. Borrower controls: log assets, leverage, risk rating. Loan controls: loan purpose, loan type. Standard errors two-way clustered by borrower and lead lender reported in parentheses. ${ }^{*}, * * * * *$ indicate significance at the 10,5 , and 1 percent levels, respectively.

likelihood of a credit reduction is nearly double if the loan is a credit line, although the difference is not statistically significant.

Columns (2)-(4) explore the importance of the syndicate structure. In column (2), the interaction variable equals 1 if the lead's share of the total commitment is above the sample median, in column (3) the interaction variable equals 1 if the number of syndicate members is below the sample median, and in column (4) the interaction variable equals 1 if the concentration (herfindahl index) of the lender shares is above the sample median. Smaller, more concentrated, syndicates and those with a larger lead share are more likely to reduce credit, and these differences are statistically significant at the $5 \%$ level. The larger effect for loans with a higher lead share is indicative 
Table 12: Heterogeneity

\begin{tabular}{|c|c|c|c|c|}
\hline \multirow{3}{*}{ Interaction variable $I$ : } & \multicolumn{4}{|c|}{ Dependent variable: Credit reduced } \\
\hline & Credit line & $\begin{array}{l}\text { High lead } \\
\text { share }\end{array}$ & $\begin{array}{c}\text { Small } \\
\text { syndicate }\end{array}$ & $\begin{array}{c}\text { Concentrated } \\
\text { syndicate }\end{array}$ \\
\hline & (1) & $(2)$ & (3) & (4) \\
\hline Bad Lender $\times$ Bind & $\begin{array}{c}16.6^{* *} \\
(7.7)\end{array}$ & $\begin{array}{l}14.5^{*} \\
(8.3)\end{array}$ & $\begin{array}{c}6.0 \\
(11.4)\end{array}$ & $\begin{array}{c}8.0 \\
(9.8)\end{array}$ \\
\hline Bad Lender $\times$ Bind $\times I$ & $\begin{array}{l}16.5 \\
(11.7)\end{array}$ & $\begin{array}{l}24.7^{* *} \\
(11.1)\end{array}$ & $\begin{array}{l}28.4^{* *} \\
(11.0)\end{array}$ & $\begin{array}{l}24.1^{* *} \\
(10.3)\end{array}$ \\
\hline Main effects & Yes & Yes & Yes & Yes \\
\hline Year, Industry FE & Yes & Yes & Yes & Yes \\
\hline Borrower, Loan Controls & Yes & Yes & Yes & Yes \\
\hline Controls $\times$ Bad Lender & Yes & Yes & Yes & Yes \\
\hline All controls $\times I$ & Yes & Yes & Yes & Yes \\
\hline Observations & 3,420 & 3,420 & 3,420 & 3,420 \\
\hline
\end{tabular}

Notes: The table reports linear probability model regressions of the form: $Y_{l, b, f, t}=\beta_{0}+\beta_{1}[$ Bad Lender $]+$ $\beta_{2}[$ Bind $]+\beta_{3}[$ Bad Lender $\times$ Bind $]+\gamma^{\prime} X_{l, b, t}+\beta_{0, I}[I]+\beta_{1, I}[$ Bad Lender $\times I]+\beta_{2, I}[$ Bind $\times I]+\beta_{3, I}[$ Bad Lender $\times$ Bind $\times I]+\gamma_{I}^{\prime}\left[X_{l, b, t} \times I\right]+\epsilon_{l, b, f, t}$. The sample is the same as table 5. The dependent variable Credit reduced equals 1 if either the loan is terminated before maturity or the loan commitment is reduced. Bad Lender is the rank of the lead lender's health normalized to lie on the unit interval, with a value of 1 corresponding to the least healthy lender. Bind is an indicator variable equal to 1 if a borrower violated a covenant in either the current or previous year. In column (1), $I$ is an indicator variable for whether the loan is a credit line. In column (2), $I$ is an indicator variable for whether the lead lender's share of the loan commitment is above the sample median. In column (3), $I$ is an indicator variable for whether the number of syndicate members is below the sample median. In column (4), $I$ is an indicator variable for whether the Herfindahl index of loan commitment shares is above the sample median. Reported coefficients are multiplied by 100. Borrower controls: log assets, leverage, risk rating. Loan controls: loan purpose, loan type. Standard errors two-way clustered by borrower and lead lender reported in parentheses. ${ }^{*}, * *, * * *$ indicate significance at the 10,5 , and 1 percent levels, respectively.

of the lead lender having a special role in the syndicate due to its monitoring and organizing responsibilities and responding to greater incentive to organize and oversee a renegotiation when it provides a larger share of the loan commitment. ${ }^{33}$ The results in columns (3) and (4) suggest that smaller, more concentrated syndicates may be easier to organize.

\footnotetext{
${ }^{33}$ Alternatively, since the variable Bad Lender reflects the health of the lead lender, the variable may simply better proxy for the true health of the pivotal syndicate member when the lead provides a larger share of the commitment. While we cannot rule out this possibility, in unreported regressions we also find a statistically significant larger treatment effect for loans with a higher lead share even when we define Bad Lender using the weighted median lender's health as described in the previous subsection. Thus, the positive interaction term appears to reflect true dependence on the lead's share.
} 


\section{Aggregation}

The previous section showed that unhealthy lenders squeeze borrowers who trigger a covenant violation and that this interaction matters to loan and borrower-level outcomes. We now quantify the importance of the loan covenant channel in accounting for the total cross-sectional variation in lender credit supply, including along the margins of expiring loans and potential new borrowers. To be clear, this aggregation exercise does not answer what would have happened to bank credit if loan covenants did not exist, in which case banks might have adjusted more on other margins, such as further restricting credit to new borrowers or reducing non-corporate lending. Rather, the exercise speaks to how especially unhealthy banks reduced lending in the actual event.

We first use our regression results to aggregate the credit decline due to the covenant channel. For this exercise, we weight both the regression and the aggregation to account for the selection into the covenant sample along the dimension of risk rating. Therefore, we start with the interaction coefficient $\beta_{3}$ from the weighted regression combining the intensive and extensive margin percent change in loan volume for loans from unhealthy lenders and that violate a covenant, shown in column (2) of table O.7. The fitted decline in lending volume (including unused commitments) due to unhealthy lenders squeezing violators implied by this coefficient is:

$$
\text { Fitted decline }=-\left(0.01 \times \beta_{3}\right) \times \sum_{l} \text { Bad Lender }{ }_{b} \times \text { Bind }_{l, t-1: t} \times \text { Commit }_{l, t-1},
$$

where Commit $_{l, t-1}$ is the loan commitment at the end of the previous year re-weighted to make the covenant review sample representative of the SNC universe along the dimension of risk rating. Dividing this sum by beginning-of-year total committed credit (including of short maturity) yields an estimate of the total fraction of credit that disappeared because unhealthy lenders contracted credit on long-term loans that violated covenants. As shown in row (1) of table 13, this share equaled $4.9 \%$ in 2008 and $5.2 \%$ in 2009 .

We put this decline in credit into context by comparing the importance of the covenant channel to the overall effect of lender health on the cross-section of credit in the crisis. To do so, we aggregate all term loans and credit lines to nonfinancial borrowers in the full SNC data set up to the bank level and regress the percent change in total committed credit between the beginning and end of the year on the variable Bad Lender. We then integrate over the measure of lender health to obtain an estimate of the total contraction in credit, including along the extensive margins of expiring and new credit, due to cross-sectional variation in lender health in each year. The 
Table 13: Aggregate Importance

$$
t=2008
$$

1. SNC covenant sample decline due to interaction

2. SNC bank-level decline due to Bad Lender
$4.9 \%$

$5.2 \%$

$8.6 \%$

$t=2009$

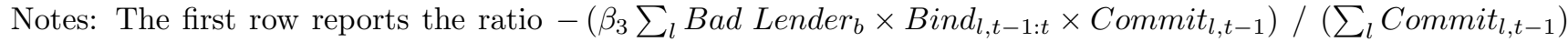
where $\beta_{3}$ comes from the re-weighted regression shown in column (2) of table O.7 and Commit $t_{l, t-1}$ denotes the beginning-of-year commitment re-weighted to make the covenant sample representative of the SNC universe

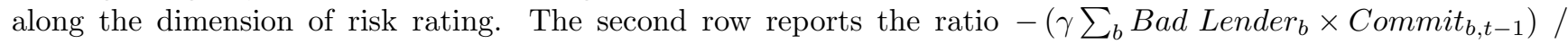
$\left(\sum_{b}\right.$ Commit $\left._{b, t-1}\right)$ where $\gamma$ comes from a regression of bank-level loan commitment growth on Bad Lender.

second row of table 13 shows that total bank credit contracted by $8.6 \%$ in 2008 and by $6.1 \%$ in 2009 relative to if each bank behaved the same as the healthiest lender along all margins. Thus, the contraction due to the covenant channel accounts for a large share of the total cross-sectional variation in lender credit supply in each year.

\section{Conclusion}

We have investigated the importance of lender health in determining the response to a covenant violation. Using a new supervisory data set of bank loans, we document a higher covenant violation propensity than found in previous work, with roughly one-third of loans breaching a covenant each year during 2008 and 2009. Lenders in worse financial condition are more likely to force a reduction in the loan balance following a violation. Quantitatively, the reduction in credit to borrowers with long-term credit but who violate a covenant accounts for a large part of the total cross-bank variation in credit supply during the crisis.

The quantitative significance of the covenant channel raises important questions for future research. We highlight four implications not explored in this paper. First, when writing loan contracts ex ante, do lenders and borrowers internalize the effective option to shorten maturity provided by covenants? Our results suggest they should. However, a body of research finds that managers may be overconfident in their outlook for their firm (Malmendier and Tate, 2015), in which case they may underestimate the likelihood of breaching a financial covenant or the consequences of doing so. Intriguingly, loans with less strict covenants became more common following firms' experiences during the 2008-09 crisis. Second, given a need for banks to delever, 
how would they have done so absent the ability to reduce credit to covenant violators, and is concentrating the credit contraction on covenant violators socially efficient? Smaller, ex ante riskier firms are more likely to violate covenants. In macroeconomic models with a financial sector, unhealthy banks typically want to reduce credit especially to riskier borrowers because the value of a marginal dollar of losses rises as the bank moves closer to its default boundary. Yet, firms with less collateral, such as R\&D intensive firms, may also have higher violation rates because of

the substitutability of collateral and covenant tightness as protection for lenders. Whether the covenant channel focuses credit reductions on those borrowers that banks would prefer to reduce exposure to even absent contractual constraints, or on R\&D intensive borrowers with a high growth path, matters for the welfare implications. Third, our evidence comes from a particularly acute crisis period. While such episodes merit special attention due to their macroeconomic importance, the pervasiveness of covenant violations in non-crisis periods means that this channel may also matter in more tranquil times. Fourth, the literature on covenants has almost exclusively used U.S. data. Yet, the transmission of bank health to corporate borrowers appears active in other countries as well. Do covenant violations abroad play as important a role as they do in the United States? If not, what is the transmission mechanism?

\section{References}

Acharya, Viral, Heitor Almeida, Filippo Ippolito, and Ander Perez (2014). "Credit lines as monitored liquidity insurance: Theory and evidence". Journal of Financial Economics 112 (3): 287-319.

- (2017). "Bank Lines of Credit as Contingent Liquidity".

Agarwal, Sumit, David Lucca, Amit Seru, and Francesco Trebbi (2014). "Inconsistent Regulators: Evidence from Banking". The Quarterly Journal of Economics 129 (2): 889-938.

Aghion, Philippe and Patrick Bolton (1992). "An Incomplete Contracts Approach to Financial Contracting". The Review of Economic Studies 59 (3): 473-494.

Almeida, Heitor, Murillo Campello, Bruno Laranjeira, and Scott Weisbenner (2012). "Corporate Debt Maturity and the Real Effects of the 2007 Credit Crisis". Critical Finance Review 1 (1): 3-58.

Almeida, Heitor, Murillo Campello, and Michael S. Weisbach (2004). "The Cash Flow Sensitivity of Cash". The Journal of Finance 59 (4): 1777-1804. 
Amiti, Mary and David Weinstein (2018). "How Much Do Idiosyncratic Bank Shocks Affect Investment? Evidence from Matched Bank-Firm Loan Data". Journal of Political Economy 126 (2): $525-587$.

Bacchetta, Philippe, Kenza Benhima, and Céline Poilly (2014). "Corporate Cash and Employment".

Benmelech, Efraim, Nittai Bergman, and Amit Seru (2015). "Financing Labor".

Bentolila, Samuel, Marcel Jansen, and Gabriel Jiménez (2017). "When Credit Dries Up: Job Losses in the Great Recession". Journal of the European Economic Association 16 (3): 650-695.

Bernanke, Ben (1983). "Nonmonetary Effects of the Financial Crisis in the Propagation of the Great Depression". American Economic Review 73 (3): 257-276.

Bernstein, Shai, Xavier Giroud, and Richard R. Townsend (2016). "The Impact of Venture Capital Monitoring". The Journal of Finance 71 (4): 1591-1622.

Bradley, Michael and Michael R. Roberts (2015). "The Structure and Pricing of Corporate Debt Covenants". Quarterly Journal of Finance 05 (02): 1550001.

Brown, James, Matthew Gustafson, and Ivan Ivanov (forthcoming). "Weathering Cash Flow Shocks". The Journal of Finance.

Brunnermeier, Markus and Yuliy Sannikov (2014). "A Macroeconomic Model with a Financial Sector". American Economic Review 104 (2): 379-421.

Campello, Murillo, Erasmo Giambona, John R. Graham, and Campbell R. Harvey (2011). "Liquidity Management and Corporate Investment During a Financial Crisis". Review of Financial Studies 24 (6): 1944-1979.

Campello, Murillo, John R. Graham, and Campbell R. Harvey (2010). "The real effects of financial constraints: Evidence from a financial crisis". Journal of Financial Economics 97 (3): 470-487.

Chava, Sudheer and Michael Roberts (2008). "How Does Financing Impact Investment? The Role of Debt Covenants". The Journal of Finance 63 (5): 2085-2121.

Chodorow-Reich, Gabriel (2014). "The Employment Effects of Credit Market Disruptions: Firmlevel Evidence from the 2008-9 Financial Crisis". The Quarterly Journal of Economics 129 (1): $1-59$.

Cornett, Marcia, Jamie McNutt, Philip Strahan, and Hassan Tehranian (2011). "Liquidity risk management and credit supply in the financial crisis". Journal of Financial Economics 101 (2): $297-312$.

Darmouni, Olivier (2016). "Estimating Informational Frictions in Sticky Relationships".

Denis, David J. and Jing Wang (2014). "Debt covenant renegotiations and creditor control rights". Journal of Financial Economics 113 (3): 348-367.

Dichev, Ilia D. and Douglas J. Skinner (2002). "Large-Sample Evidence on the Debt Covenant Hypothesis". Journal of Accounting Research 40 (4): 1091-1123. 
Duchin, Ran, Oguzhan Ozbas, and Berk A. Sensoy (2010). "Costly external finance, corporate investment, and the subprime mortgage credit crisis". Journal of Financial Economics 97 (3): $418-435$.

Duygan-Bump, Burcu, Alexey Levkov, and Judit Montoriol-Garriga (2015). "Financing constraints and unemployment: Evidence from the Great Recession". Journal of Monetary Economics 75: 89-105.

Erel, Isil, Taylor Nadauld, and Rene Stulz (2011). "Why Did U.S. Banks Invest in Highly-rated Securitization Tranches?"

Fahlenbrach, Rudiger, Robert Prilmeier, and Rene Stulz (2012). "This Time is the Same: Using Bank Performance in 1998 to Explain Bank Performance During the Recent Financial Crisis". Journal of Finance 67 (6): 2139-2185.

Falato, Antonio and Nellie Liang (2016). "Do Creditor Rights Increase Employment Risk? Evidence from Loan Covenants". The Journal of Finance 71 (6): 2545-2590.

Freudenberg, Felix, Björn Imbierowicz, Anthony Saunders, and Sascha Steffen (2015). "Covenant Violations and Dynamic Loan Contracting".

Gan, Jie (2007). "The Real Effects of Asset Market Bubbles: Loan- and Firm-Level Evidence of a Lending Channel". The Review of Financial Studies 20 (6): 1941-1973.

Gârleanu, Nicolae and Jeffrey Zwiebel (2009). "Design and Renegotiation of Debt Covenants". Review of Financial Studies 22 (2): 749-781.

Gertler, Mark and Nobuhiro Kiyotaki (2010). "Chapter 11 - Financial Intermediation and Credit Policy in Business Cycle Analysis". In: Handbook of Monetary Economics. Ed. by Benjamin M. Friedman and Michael Woodford. Vol. 3. Elsevier, p. 547-599.

Giroud, Xavier (2013). "Proximity and Investment: Evidence from Plant-Level Data". The Quarterly Journal of Economics 128 (2): 861-915.

Greenwald, Daniel (2019). "Firm Debt Covenants and the Macroeconomy: The Interest Coverage Channel".

Hachem, Kinda (2011). "Relationship lending and the transmission of monetary policy". Journal of Monetary Economics 58 (6-8): 590-600.

Hart, Oliver and John Moore (1988). "Incomplete Contracts and Renegotiation". Econometrica 56 (4): $755-785$.

He, Zhiguo and Arvind Krishnamurthy (2013). "Intermediary Asset Pricing". American Economic Review 103 (2): 732-70.

Huang, Rocco (2010). "How Committed are Bank Lines of Credit? Experiences in the Subprime Mortgage Crisis".

Imbens, Guido W. and Thomas Lemieux (2008). "Regression discontinuity designs: A guide to practice". Journal of Econometrics 142 (2): 615-635.

Ivashina, Victoria and David Scharfstein (2010). "Bank Lending During the Financial Crisis of 2008". Journal of Financial Economics 97 (3): 319-338. 
Khwaja, Asim Ijaz and Atif Mian (2008). "Tracing the Impact of Bank Liquidity Shocks: Evidence from an Emerging Market". American Economic Review 98 (4): 1413-1442.

Lee, David S. and Thomas Lemieux (2010). "Regression Discontinuity Designs in Economics". Journal of Economic Literature 48 (2): 281-355.

Lian, Chen and Yueran Ma (2019). "Anatomy of Corporate Borrowing Constraints".

Lin, Huidan and Daniel Paravisini (2012). "The Effect of Financing Constraints on Risk". Review of Finance 17 (1): 229-259.

Malmendier, Ulrike and Geoffrey Tate (2015). "Behavioral CEOs: The Role of Managerial Overconfidence". Journal of Economic Perspectives 29 (4): 37-60.

McCrary, Justin (2008). "Manipulation of the running variable in the regression discontinuity design: A density test". Journal of Econometrics 142 (2): 698-714.

Melcangi, Davide (2016). "Firms' Precautionary Savings and Employment During a Credit Crisis".

Mian, Atif and João Santos (2018). "Liquidity risk and maturity management over the credit cycle". Journal of Financial Economics 127 (2): 264-284.

Murfin, Justin (2012). "The Supply-Side Determinants of Loan Contract Strictness". The Journal of Finance 67 (5): 1565-1601.

Nini, Greg, David C. Smith, and Amir Sufi (2009). "Creditor control rights and firm investment policy". Journal of Financial Economics 92 (3): 400-420.

- (2012). "Creditor Control Rights, Corporate Governance, and Firm Value". Review of Financial Studies 25 (6): 1713-1761.

Peek, Joe and Eric Rosengren (2000). "Collateral Damage: Effects of the Japanese Bank Crisis on Real Activity in the United States". American Economic Review 90 (1): 30-45.

Roberts, Michael (2015). "The role of dynamic renegotiation and asymmetric information in financial contracting". Journal of Financial Economics 116 (1): 61-81.

Roberts, Michael and Amir Sufi (2009a). "Control Rights and Capital Structure: An Empirical Investigation". The Journal of Finance 64 (4): 1657-1695.

- (2009b). "Renegotiation of financial contracts: Evidence from private credit agreements". Journal of Financial Economics 93 (2): 159-184.

Santos, Joao (2011). "Bank Corporate Loan Pricing Following the Subprime Crisis". Review of Financial Studies 24 (6): 1916-1943.

Schwert, Michael (2018). "Bank Capital and Lending Relationships". The Journal of Finance 73 (2): 787-830.

Sharpe, Steven (1990). "Asymmetric Information, Bank Lending and Implicit Contracts: A Stylized Model of Customer Relationships". The Journal of Finance 45 (4): 1069-1087.

Siemer, Michael (2016). "Employment Effects of Financial Constraints During the Great Recession". 
Sufi, Amir (2007). "Information Asymmetries and Financing Arrangements: Evidence from Syndicated Loans". Journal of Finance 62 (2): 629-668.

Williamson, Stephen (1987). "Costly Monitoring, Loan Contracts, and Equilibrium Credit Rationing". The Quarterly Journal of Economics 102 (1): 135-146.

Xiao, Jasmine (2017). "Corporate Debt Structure, Precautionary Savings, and Investment Dynamics". 
Table A.1: Loan Covenants in the Sample Credit Agreement

\begin{tabular}{|c|c|}
\hline Affirmative Covenants & Negative Covenants \\
\hline $\begin{array}{l}\text { Financial statements and other information } \\
(6.01) \\
\text { Notices of material events ( } 6.02) \\
\text { Existence; conduct of business (6.03) } \\
\text { Payment of obligations (6.04) } \\
\text { Maintenance of properties (6.05) } \\
\text { Books and records; inspection rights (6.06) } \\
\text { Compliance with laws (6.07) } \\
\text { Use of proceeds (6.08) } \\
\text { Notice of certain changes (6.09) } \\
\text { Insurance (6.10) } \\
\text { Additional subsidiaries (6.11) } \\
\text { Information regarding collateral (6.12) } \\
\text { Casualty and condemnation (6.13) } \\
\text { Intellectual property; further assurances } \\
\text { (6.14) }\end{array}$ & $\begin{array}{l}\text { Indebtedness (7.01) } \\
\text { Liens }(7.02) \\
\text { Fundamental changes (7.03) } \\
\text { Investments, loans, advances, guarantees and } \\
\text { acquisitions (7.04) } \\
\text { Asset sales (7.05) } \\
\text { Sale and lease-back transactions (7.06) } \\
\text { Hedging agreements (7.07) } \\
\text { Restricted payments }(7.08) \\
\text { Transactions with affiliates (7.09) } \\
\text { Restrictive agreements }(7.10) \\
\text { Amendment of material documents }(7.11) \\
\text { Leverage ratio (7.12) } \\
\text { Interest coverage ratio (7.13) } \\
\text { Prepayments of indebtedness (7.14) } \\
\text { Capital expenditures (7.15) } \\
\text { Fiscal year (7.16) } \\
\text { ERISA obligations (7.17) }\end{array}$ \\
\hline
\end{tabular}




\section{Figure A.1: Comparison of SNC to Call Report Data}

\section{Loans Outstanding}

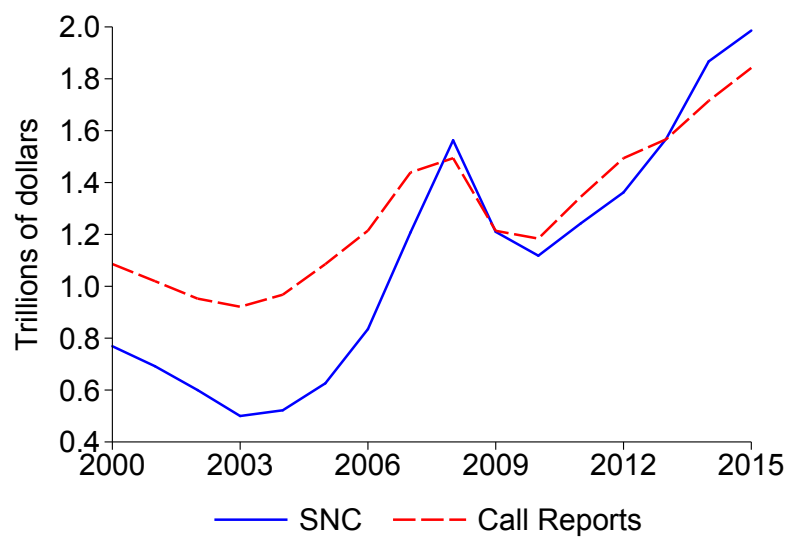

Unused Commitments



Notes: The left panel plots the dollar amount of SNC loans outstanding and Consolidated Reports of Condition and Income (Call Reports) commercial and industrial loans. The right panel plots the dollar amount of SNC unused loan commitments and Call Report unused commitments not associated with real estate or credit cards. SNC data: https://www.federalreserve.gov/newsevents/pressreleases/files/bcreg20160729a1.pdf (accessed March 27, 2017). Aggregated Call Report data from the FDIC Quarterly Banking Profile: https ://www.fdic.gov/bank/ analytical/qbp/timeseries/BalanceSheet.xls (accessed November 2, 2016).

Figure A.2: SNC Sample Comparison

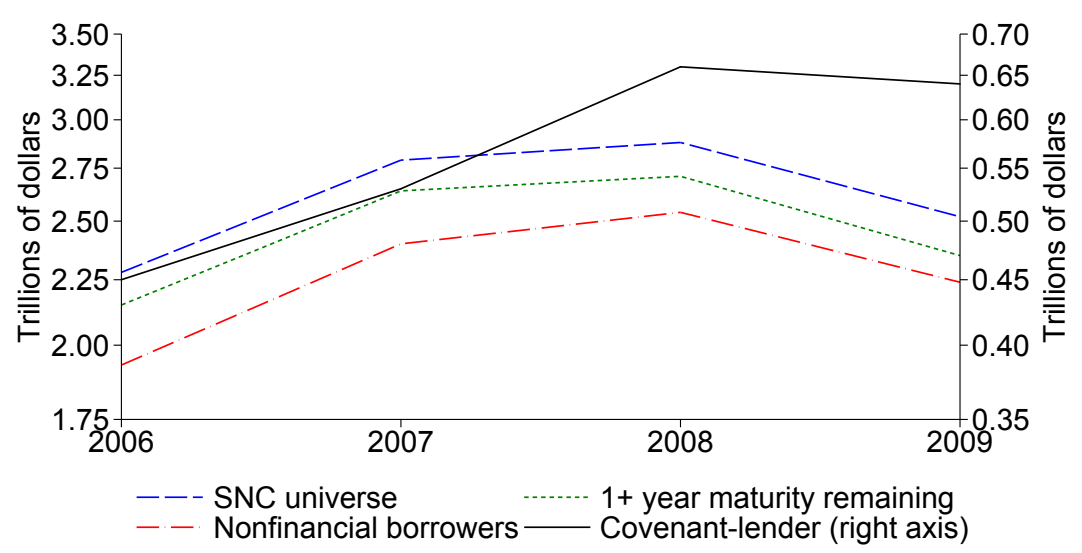

Notes: The figure reports the dollar amount of total loans outstanding and unused commitments in the SNC universe (blue line); the preceding less loans with less than one year maturity remaining (green line); the preceding less loans to financial borrowers (red line); and in our final sample of all term loans and credit lines to nonfinancial borrowers in the SNC covenant sample with a lead lender in the Chodorow-Reich (2014) data set and which start the year with at least one year of maturity remaining. 


\title{
The Loan Covenant Channel: \\ How Bank Health Transmits to the Real Economy
}

\author{
Online Appendix \\ Gabriel Chodorow-Reich Antonio Falato
}

\section{O.1. Additional Results}

This appendix reports additional results. Figure O.1 reports the share of loans attributed to each (anonymized) lead lender in the full SNC universe and the SNC covenant sample. Figure O.2 reports the standardized lender health for each (anonymized) lender. Table O.1 reports the coefficients and t-statistics from regressions of borrower and loan characteristics on the continuous variable Bad Lender. Table O.2 reports placebo first-stage results that replace Bind with Bad Lender as the left hand side variable. Table O.3 repeats the non-parametric analysis at the level of the borrower and including expiring loans. Table O.4 reports robustness to inclusion of additional covariates. Table O.5 reports additional specifications related to the regression discontinuity exercises. Table O.6 reports additional robustness of the instrumental variables specifications. Tables O.7 and O.8 repeat the sample robustness shown in table 10 of the main text but for the outcome $\% \Delta$ Total committed at the loan (all margins) and borrower level, respectively. 
Figure O.1: Lender Concentration in SNC

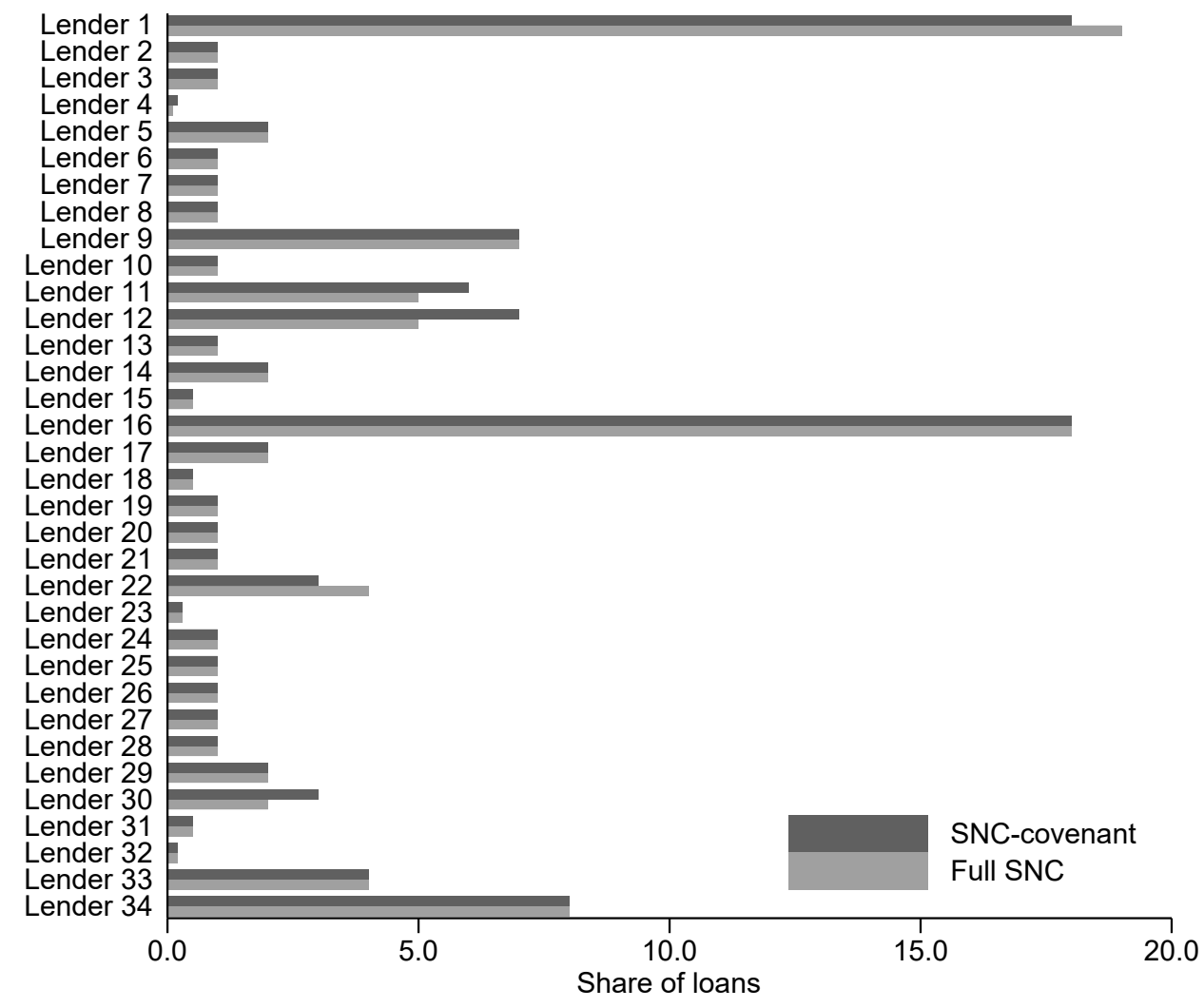

Notes: The figure reports the share of loans attributed to each (anonymized) lead lender in the full SNC universe and the SNC covenant sample. 
Figure O.2: Lender Health Distribution

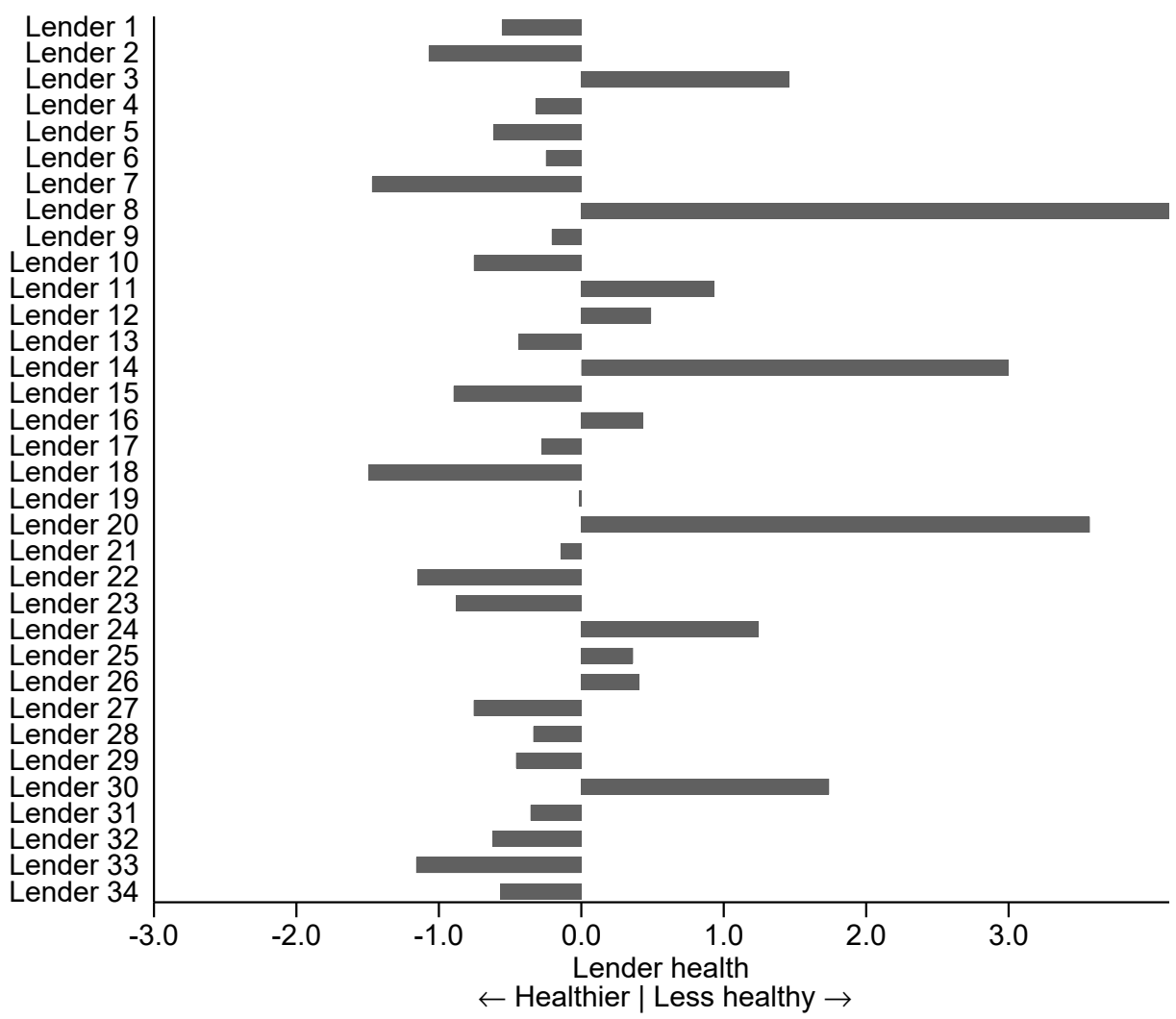

Notes: The figure reports the lender health measure for each (anonymized) lender, standardized to have zero mean and unit variance when weighted by the shares shown in figure O.1. 
Table O.1: Balancing using Continuous Measure of Lender Health

\begin{tabular}{|c|c|c|c|c|}
\hline & \multicolumn{2}{|c|}{ All borrowers } & \multicolumn{2}{|c|}{$\operatorname{Bind}_{t-1: t}=1$} \\
\hline & Coefficient & t-statistic & Coefficient & t-statistic \\
\hline & (1) & $(2)$ & (3) & (4) \\
\hline & \multicolumn{4}{|c|}{ Panel A: SNC pre-crisis variables } \\
\hline Covenant tightness & 0.31 & 1.05 & & \\
\hline Log assets & -0.15 & 1.11 & -0.16 & 1.14 \\
\hline Leverage & -0.02 & 0.44 & -0.03 & 0.85 \\
\hline Risk rating & 0.29 & 0.73 & -0.17 & 0.01 \\
\hline & \multicolumn{4}{|c|}{ Panel B: Compustat pre-crisis variables } \\
\hline Cash flow/assets (\%) & 0.04 & 1.02 & -0.01 & 0.34 \\
\hline $\mathrm{ROA}(\%)$ & -0.01 & 0.56 & -0.02 & 0.88 \\
\hline Tobin's Q & -0.10 & 0.51 & -0.24 & 1.17 \\
\hline Z-score & 0.25 & 1.04 & 0.35 & 0.92 \\
\hline Disc. accruals/assets (\%) & -0.00 & 0.22 & 0.00 & 0.07 \\
\hline $\mathrm{S} \& \mathrm{P}$ credit rating $(\%)$ & -0.04 & 0.28 & -0.17 & 0.70 \\
\hline Bankruptcy or delisting & -0.06 & 1.19 & -0.06 & 1.14 \\
\hline Market beta & 0.00 & 0.32 & 0.00 & 0.30 \\
\hline Idiosyncratic volatility & 0.03 & 0.14 & 0.03 & 0.49 \\
\hline Total volatility & 0.02 & 0.72 & 0.02 & 0.74 \\
\hline $100 \times$ Bind $_{t-1 \cdot t}$ & \multicolumn{4}{|c|}{ Panel C: $S N C$ crisis variables } \\
\hline
\end{tabular}

Notes: The table reports the regression coefficient and t-statistic from a regression of the variable indicated in Bad Lender. 
Table O.2: Placebo First Stage

\begin{tabular}{lcccc}
\hline \hline Dependent variable: & \multicolumn{4}{c}{ Bad Lender } \\
\cline { 2 - 5 } & $(1)$ & $(2)$ & $(3)$ & $(4)$ \\
\hline \multirow{2}{*}{ New Route } & & & & 0.0 \\
& -1.6 & & & $(0.5)$ \\
Airline Bankruptcy & $(1.6)$ & & 0.1 \\
& -3.4 & 0.0 & $(0.5)$ \\
Lax Supervisor & $(3.6)$ & $(0.3)$ & & -0.1 \\
& & & 0.1 & $(0.7)$ \\
Abnormal Snow & & & $(0.6)$ & -0.7 \\
& & Yes & Yes & Yes \\
Controls & Yes & 0.0 & 0.1 & 0.2 \\
Partial F-statistic & 1.1 & 3,420 & 3,420 & 3,420 \\
Observations & 3,420 & & \\
\hline \hline
\end{tabular}

Notes: The table reports placebo regressions for the excluded instruments predicting Bad Lender. The sample consists of all loans in the SNC covenant sample at the start of 2008 or 2009 with at least one year maturity remaining and a lead lender in the lender health data set. Bad Lender is the rank of the lead lender's health normalized to lie on the unit interval, with a value of 1 corresponding to the least healthy lender. Controls: year, industry, log assets, leverage, risk rating, the interaction of each with Bad Lender, and loan purpose and loan type. Standard errors two-way clustered by borrower and lead lender reported in parentheses. *,**,*** indicate significance at the 10,5 , and 1 percent levels, respectively.

Table O.3: Non-parametric Evidence Including Expiring Loans

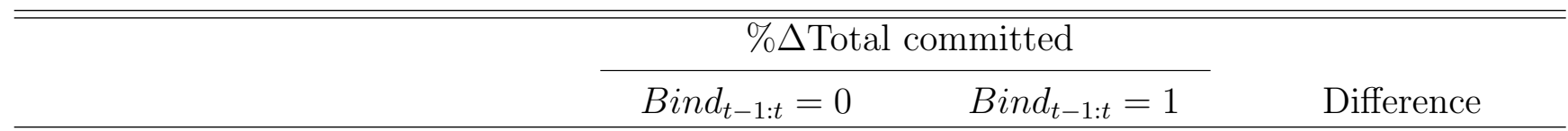

Lender health quartile:

$\begin{array}{lcll}\text { Quartile 1 (healthiest lenders) } & 0.005 & -0.060 & -0.065 \\ & {[\mathrm{~N}=596]} & {[\mathrm{N}=360]} & \\ \text { Quartile 2 } & 0.017 & -0.069 & -0.086 \\ & {[\mathrm{~N}=580]} & {[\mathrm{N}=385]} & \\ \text { Quartile 3 } & 0.030 & -0.134 & -0.164 \\ & {[\mathrm{~N}=568]} & {[\mathrm{N}=394]} & \\ \text { Quartile 4 (least healthy lenders) } & 0.039 & -0.146 & -0.185 \\ & {[\mathrm{~N}=550]} & {[\mathrm{N}=410]} & \\ \text { Difference Q4-Q1 } & 0.034 & -0.086 & -0.120\end{array}$

Notes: The table reports the average change in loan commitment in each cell. The sample consists of all loans in the SNC covenant sample at the start of 2008 or 2009, including those with expiring loans, and with a lead lender in the lender health data set. Bad Lender is the rank of the lead lender's health normalized to lie on the unit interval, with a value of 1 corresponding to the least healthy lender. Bind is an indicator variable equal to 1 if a borrower violated a covenant in either the current or previous year. The brackets report the number of observations in each cell. 
Table O.4: Controls Robustness

\begin{tabular}{|c|c|c|c|c|}
\hline \multirow{4}{*}{$\begin{array}{l}\text { Sample: } \\
\text { Controls: }\end{array}$} & \multicolumn{4}{|c|}{ Dependent variable: Credit Reduced } \\
\hline & \multicolumn{2}{|c|}{ Baseline } & \multicolumn{2}{|c|}{ SNC-Compustat } \\
\hline & Baseline & Augmented & Baseline & Augmented \\
\hline & $(1)$ & $(2)$ & $(3)$ & $(4)$ \\
\hline \multirow[t]{2}{*}{ Bad Lender } & 5.8 & 8.2 & -6.2 & -2.9 \\
\hline & $(12.1)$ & $(11.1)$ & $(16.7)$ & $(19.6)$ \\
\hline \multirow[t]{2}{*}{ Bind } & $5.6^{* *}$ & $6.6^{* *}$ & 0.2 & -1.7 \\
\hline & $(2.7)$ & $(2.8)$ & $(5.9)$ & $(7.1)$ \\
\hline \multirow[t]{2}{*}{ Bad Lender $\times$ Bind } & $22.9^{* * *}$ & $20.3^{* * *}$ & $46.5^{* * *}$ & $47.7^{* * *}$ \\
\hline & $(6.7)$ & $(7.2)$ & $(15.7)$ & $(19.3)$ \\
\hline Additional borrower controls & No & Yes & No & Yes \\
\hline Controls $\times$ Bad Lender & Yes & Yes & Yes & Yes \\
\hline$R^{2}$ & 0.116 & 0.123 & 0.189 & 0.192 \\
\hline Observations & 3,420 & 3,420 & 1,260 & 1,260 \\
\hline
\end{tabular}

Notes: The table reports linear probability model regressions of the form: $Y_{l, b, f, t}=\beta_{0}+\beta_{1}[$ Bad Lender $]+$ $\beta_{2}[$ Bind $]+\beta_{3}[$ Bad Lender $\times$ Bind $]+\gamma^{\prime} X_{l, b, f, t}+\epsilon_{l, b, f, t}$. Column (1) reproduces our baseline. Column (2) augments the control set with size squared, leverage squared, single lender borrower, syndicate lead share, syndicate size, and syndicate concentration. Column (3) reproduces the baseline specification within the merged SNC-Compustat sample. Column (4) augments the control set with borrower cash flow, return on assets, Tobin's Q, z-score, discretionary accruals, and an indicator for having an S\&P credit rating. Bad Lender is the rank of the lead lender's health normalized to lie on the unit interval, with a value of 1 corresponding to the least healthy lender. Bind is an indicator variable equal to 1 if a borrower violated a covenant in either the current or previous year. Reported coefficients are multiplied by 100. Borrower controls: log assets, leverage, risk rating. Standard errors two-way clustered by borrower and lead lender reported in parentheses. ${ }^{*}, * * * *$ indicate significance at the 10,5 , and 1 percent levels, respectively. 
Table O.5: Regression Discontinuity Robustness

\begin{tabular}{|c|c|c|c|c|c|c|}
\hline \multirow{4}{*}{$\begin{array}{l}\text { Bandwidth: } \\
\text { Polynomial: }\end{array}$} & \multicolumn{6}{|c|}{ Dependent variable: Credit reduced } \\
\hline & \multicolumn{3}{|c|}{$30 \%$} & \multicolumn{3}{|c|}{$20 \%$} \\
\hline & Linear & Quadratic & Cubic & Linear & Quadratic & Cubic \\
\hline & (1) & (2) & (3) & (4) & (5) & (6) \\
\hline Bad Lender & $\begin{array}{c}11.1 \\
(10.4)\end{array}$ & $\begin{array}{c}11.0 \\
(10.3)\end{array}$ & $\begin{array}{c}11.1 \\
(10.2)\end{array}$ & $\begin{array}{c}15.3 \\
(23.9)\end{array}$ & $\begin{array}{c}15.3 \\
(23.5)\end{array}$ & $\begin{array}{c}15.2 \\
(23.6)\end{array}$ \\
\hline Bind & $\begin{array}{c}6.7 \\
(4.3)\end{array}$ & $\begin{array}{c}6.2 \\
(4.5)\end{array}$ & $\begin{array}{c}6.6 \\
(4.3)\end{array}$ & $\begin{array}{c}3.3 \\
(5.8)\end{array}$ & $\begin{array}{c}2.6 \\
(5.9)\end{array}$ & $\begin{array}{c}3.1 \\
(5.8)\end{array}$ \\
\hline Bad Lender $\times$ Bind & $\begin{array}{c}23.0^{* *} \\
(11.0)\end{array}$ & $\begin{array}{c}24.4^{* *} \\
(12.2)\end{array}$ & $\begin{array}{r}23.2^{*} \\
(11.0)\end{array}$ & $\begin{array}{c}24.8^{* *} \\
(11.3)\end{array}$ & $\begin{array}{c}26.5^{* *} \\
(12.4)\end{array}$ & $\begin{array}{c}25.1^{* *} \\
(11.3)\end{array}$ \\
\hline Year, Industry FE & Yes & Yes & Yes & Yes & Yes & Yes \\
\hline Borrower, loan, distance controls & Yes & Yes & Yes & Yes & Yes & Yes \\
\hline Controls $\times$ Bad Lender & Yes & Yes & Yes & Yes & Yes & Yes \\
\hline Observations & 780 & 780 & 780 & 489 & 489 & 489 \\
\hline
\end{tabular}

Notes: The table reports linear probability model regressions of the form: $Y_{l, b, f, t}=\beta_{0}+\beta_{1}[$ Bad Lender $]+$ $\beta_{2}[$ Bind $]+\beta_{3}[$ Bad Lender $\times$ Bind $]+\gamma^{\prime} X_{l, b, t}+\epsilon_{l, b, f, t}$. The sample consists of loans for which the absolute value of the distance to a covenant threshold is less than $30 \%$ (columns 1-3) or $20 \%$ (columns 4-6). In all columns, the dependent variable Credit reduced equals 1 if either the loan is terminated before maturity or the loan commitment is reduced; Bad Lender is normalized to lie on the unit interval, with a value of 1 corresponding to the least healthy lender; and Bind is an indicator variable which equals 1 if a borrower violated a covenant in either the current or previous year. Reported coefficients are multiplied by 100. Borrower controls: log assets, leverage, risk rating. Loan controls: loan purpose, loan type. Standard errors two-way clustered by borrower and lead lender reported in parentheses. ${ }^{*}, * *, * * *$ indicate significance at the 10,5 , and 1 percent levels, respectively. 
Table O.6: Instrumental Variables Robustness

\begin{tabular}{lccccc}
\hline \hline Dependent variable: & \multicolumn{5}{c}{ Credit reduced } \\
\cline { 2 - 6 } & $(1)$ & $(2)$ & $(3)$ & $(4)$ & $(5)$ \\
\hline \multirow{3}{*}{ Bad Lender } & 5.3 & & 1.5 & & \\
& $(7.5)$ & & $(2.2)$ & & \\
Bind & 0.2 & 5.2 & 0.3 & 3.3 & 4.4 \\
& $(24.1)$ & $(4.9)$ & $(15.8)$ & $(14.3)$ & $(19.6)$ \\
Bad Lender $\times$ Bind & $52.0^{*}$ & $16.9^{* * *}$ & $56.5^{* *}$ & $34.2^{* * *}$ & $27.6^{* * *}$ \\
& $(26.9)$ & $(3.9)$ & $(23.2)$ & $(11.4)$ & $(9.7)$ \\
\hline Estimator & IV & IV & IV & IV & IV \\
Excluded instrument & Travel & Supervisor & Snow & All & All \\
Year, Industry FE & Yes & Yes & Yes & Yes & Yes \\
Borrower, loan controls & Yes & Yes & Yes & Yes & Yes \\
Controls $\times$ Bad Lender & Yes & Yes & Yes & Yes & Yes \\
Borrower county $\times$ year FE & Yes & No & No & No & No \\
Lender county $\times$ year FE & Yes & No & No & No & No \\
Borrower county FE & No & No & Yes & No & Yes \\
Lender FE & No & Yes & No & Yes & Yes \\
Observations & 3,420 & 3,420 & 3,420 & 3,420 & 3,420 \\
\hline \hline
\end{tabular}

Notes: The table reports linear probability model regressions of the form: $Y_{l, b, f, t}=\beta_{0}+\beta_{1}[$ Bad Lender $]+$ $\beta_{2}[$ Bind $]+\beta_{3}[$ Bad Lender $\times$ Bind $]+\gamma^{\prime} X_{l, b, t}+\epsilon_{l, b, f, t}$. The sample consists of all loans in the SNC covenant sample at the start of 2008 or 2009 with at least one year maturity remaining and a lead lender in the lender health data set.The variable Credit reduced equals 1 if either the loan is terminated before maturity or the loan commitment is reduced. Bad Lender is the rank of the lead lender's health normalized to lie on the unit interval, with a value of 1 corresponding to the least healthy lender. Bind is an indicator variable equal to 1 if a borrower violated a covenant in either the current or previous year. Reported coefficients are multiplied by 100 . Borrower controls: log assets, leverage, risk rating. Loan controls: loan purpose, loan type. Standard errors two-way clustered by borrower and lead lender reported in parentheses. ${ }^{* * *},{ }^{* *}$ indicate significance at the 10,5 , and 1 percent levels, respectively. 
Table O.7: Sample Robustness

\begin{tabular}{|c|c|c|c|c|c|c|c|c|c|}
\hline \multirow{3}{*}{ Sample: } & \multicolumn{9}{|c|}{ Dependent variable: $\% \Delta$ Total committed, loan-level } \\
\hline & Baseline & $\begin{array}{c}\text { Re- } \\
\text { weighted }\end{array}$ & $\begin{array}{l}\text { Only } \\
\text { "Best" } \\
\text { rating }\end{array}$ & $\begin{array}{l}\text { Drop if } \\
\text { existing } \\
\text { violator }\end{array}$ & $\begin{array}{l}\text { Include } \\
\text { expiring } \\
\text { loans }\end{array}$ & $\begin{array}{l}2+\text { years } \\
\text { maturity }\end{array}$ & $\begin{array}{l}\text { Drop if } \\
\text { all sold }\end{array}$ & Add NSS & $\begin{array}{c}\text { Add } \\
\text { DealScan }\end{array}$ \\
\hline & $(1)$ & $(2)$ & $(3)$ & $(4)$ & $(5)$ & $(6)$ & $(7)$ & $(8)$ & $(9)$ \\
\hline Bad Lender & $\begin{array}{c}6.3 \\
(14.0)\end{array}$ & $\begin{array}{c}4.2 \\
(14.2)\end{array}$ & $\begin{array}{c}0.4 \\
(19.0)\end{array}$ & $\begin{array}{c}6.5 \\
(16.1)\end{array}$ & $\begin{array}{c}11.1 \\
(13.5)\end{array}$ & $\begin{array}{c}10.8 \\
(13.8)\end{array}$ & $\begin{array}{c}11.7 \\
(16.5)\end{array}$ & $\begin{array}{c}0.2 \\
(13.0)\end{array}$ & $\begin{array}{c}3.6 \\
(10.7)\end{array}$ \\
\hline Bind & $\begin{array}{c}-8.5^{* *} \\
(3.7)\end{array}$ & $\begin{array}{c}-9.1^{* *} \\
(3.5)\end{array}$ & $\begin{array}{c}-5.9 \\
(7.0)\end{array}$ & $\begin{array}{r}-7.7 \\
(6.9)\end{array}$ & $\begin{array}{c}-8.9^{* *} \\
(3.8)\end{array}$ & $\begin{array}{r}-1.3 \\
(4.5)\end{array}$ & $\begin{array}{c}-9.4^{* *} \\
(3.8)\end{array}$ & $\begin{array}{c}-1.9 \\
(5.4)\end{array}$ & $\begin{array}{l}-1.6 \\
(5.3)\end{array}$ \\
\hline Bad Lender $\times$ Bind & $\begin{array}{c}-24.4^{* * *} \\
(14.0)\end{array}$ & $\begin{array}{c}-22.3^{* * *} \\
(7.1)\end{array}$ & $\begin{array}{c}-20.2^{* * *} \\
(6.1)\end{array}$ & $\begin{array}{c}-28.0^{* * *} \\
(8.7)\end{array}$ & $\begin{array}{c}-25.1^{* * *} \\
(6.3)\end{array}$ & $\begin{array}{c}-32.7^{* * *} \\
(12.9)\end{array}$ & $\begin{array}{c}-29.5^{* * *} \\
(7.4)\end{array}$ & $\begin{array}{c}-24.8^{* *} \\
(11.4)\end{array}$ & $\begin{array}{c}-21.9^{* *} \\
(9.8)\end{array}$ \\
\hline Year, Industry FE & Yes & Yes & Yes & Yes & Yes & Yes & Yes & Yes & Yes \\
\hline Borrower, loan controls & Yes & Yes & Yes & Yes & Yes & Yes & Yes & Yes & Yes \\
\hline Controls $\times$ Bad Lender & Yes & Yes & Yes & Yes & Yes & Yes & Yes & Yes & Yes \\
\hline Observations & 3,420 & 3,420 & 1,572 & 2,735 & 3,843 & 2,702 & 3,118 & 4,765 & 5,005 \\
\hline
\end{tabular}

Notes: The table reports regressions of the form: $Y_{l, b, f, t}=\beta_{0}+\beta_{1}[$ Bad Lender $]+\beta_{2}[$ Bind $]+\beta_{3}[$ Bad Lender $\times$ Bind $]+\gamma^{\prime} X_{l, b, f, t}+\epsilon_{l, b, f, t}$. Column $(1)$ reproduces our baseline. Column (2) reweights the sample to match the distribution of risk ratings in the full SNC universe. Column (3) only includes loans with a pre-crisis rating of "Best". Column (4) excludes loans that violated a covenant before the crisis. Column (5) includes loans with less than 1 year maturity remaining. Column (6) only includes loans with at least 2 years maturity remaining. Column (7) excludes loans for which the lead lender does not retain any part of its share. Columns (8) and (9) expand the sample by including information on covenant compliance from Nini, Smith, and Sufi (2012) and from DealScan, respectively. The dependent variable is the percent change in total committed credit on loans from lead lender $b$ to borrower $f$. Bad Lender is the rank of the lead lender's health normalized to lie on the unit interval, with a value of 1 corresponding to the least healthy lender. Bind is an indicator variable equal to 1 if a borrower violated a covenant in either the current or previous year. Reported coefficients are multiplied by 100. Borrower controls: log assets, leverage, risk rating. Loan controls: loan purpose, loan type. Standard errors two-way clustered by borrower and lead lender reported in parentheses. ${ }^{*}, * * * *$ indicate significance at the 10,5 , and 1 percent levels, respectively. 
Table O.8: Sample Robustness

\begin{tabular}{|c|c|c|c|c|c|c|c|c|c|}
\hline \multirow{3}{*}{ Sample: } & \multicolumn{9}{|c|}{ Dependent variable: $\% \Delta$ Total committed, borrower-level } \\
\hline & Baseline & $\begin{array}{c}\text { Re- } \\
\text { weighted }\end{array}$ & $\begin{array}{l}\text { Only } \\
\text { "Best" } \\
\text { rating }\end{array}$ & $\begin{array}{l}\text { Drop if } \\
\text { existing } \\
\text { violator }\end{array}$ & $\begin{array}{l}\text { Include } \\
\text { expiring } \\
\text { loans }\end{array}$ & $\begin{array}{l}2+\text { years } \\
\text { maturity }\end{array}$ & $\begin{array}{l}\text { Drop if } \\
\text { all sold }\end{array}$ & Add NSS & $\begin{array}{c}\text { Add } \\
\text { DealScan }\end{array}$ \\
\hline & $(1)$ & $(2)$ & $(3)$ & (4) & $(5)$ & (6) & $(7)$ & $(8)$ & $(9)$ \\
\hline Bad Lender & $\begin{array}{c}6.2 \\
(13.4)\end{array}$ & $\begin{array}{l}-0.3 \\
(12.1)\end{array}$ & $\begin{array}{c}9.2 \\
(12.9)\end{array}$ & $\begin{array}{c}12.1 \\
(19.4)\end{array}$ & $\begin{array}{c}9.6 \\
(10.0)\end{array}$ & $\begin{array}{c}11.4 \\
(17.8)\end{array}$ & $\begin{array}{r}-1.2 \\
(8.5)\end{array}$ & $\begin{array}{c}9.3 \\
(12.0)\end{array}$ & $\begin{array}{c}7.1 \\
(10.9)\end{array}$ \\
\hline Bind & $\begin{array}{c}-6.3^{* *} \\
(3.1)\end{array}$ & $\begin{array}{c}-3.2 \\
(6.8)\end{array}$ & $\begin{array}{c}-3.5 \\
(3.1)\end{array}$ & $\begin{array}{c}-5.2 \\
(5.0)\end{array}$ & $\begin{array}{c}-5.8^{* *} \\
(2.7)\end{array}$ & $\begin{array}{c}-4.1 \\
(4.3)\end{array}$ & $\begin{array}{c}-2.0 \\
(2.4)\end{array}$ & $\begin{array}{c}-6.9^{* * *} \\
(2.3)\end{array}$ & $\begin{array}{c}-6.2^{* *} \\
(2.4)\end{array}$ \\
\hline Bad Lender $\times$ Bind & $\begin{array}{c}-30.1^{* * *} \\
(10.3)\end{array}$ & $\begin{array}{c}-26.4^{* * *} \\
(8.9)\end{array}$ & $\begin{array}{c}-24.1^{* * *} \\
(8.6)\end{array}$ & $\begin{array}{c}-33.5^{* * *} \\
(11.2)\end{array}$ & $\begin{array}{c}-29.3^{* * *} \\
(8.4)\end{array}$ & $\begin{array}{c}-33.4^{* * *} \\
(11.0)\end{array}$ & $\begin{array}{c}-30.7^{* * *} \\
(6.7)\end{array}$ & $\begin{array}{c}-28.8^{* * *} \\
(8.8)\end{array}$ & $\begin{array}{c}-28.2^{* * *} \\
(8.5)\end{array}$ \\
\hline Year, Industry FE & Yes & Yes & Yes & Yes & Yes & Yes & Yes & Yes & Yes \\
\hline Borrower controls & Yes & Yes & Yes & Yes & Yes & Yes & Yes & Yes & Yes \\
\hline Controls $\times$ Bad Lender & Yes & Yes & Yes & Yes & Yes & Yes & Yes & Yes & Yes \\
\hline Observations & 1,803 & 1,803 & 884 & 1,432 & 1,833 & 1,524 & 1,606 & 2,436 & 2,540 \\
\hline
\end{tabular}

Notes: The table reports regressions of the form: $Y_{b, f, t}=\beta_{0}+\beta_{1}[$ Bad Lender $]+\beta_{2}[$ Bind $]+\beta_{3}[$ Bad Lender $\times$ Bind $]+\gamma^{\prime} X_{l, f, t}+\epsilon_{l, f, t}$. Column (1) reproduces our baseline. Column (2) reweights the sample to match the distribution of risk ratings in the full SNC universe. Column (3) only includes loans with a pre-crisis rating of "Best". Column (4) excludes loans that violated a covenant before the crisis. Column (5) includes loans with less than 1 year maturity remaining. Column (6) only includes loans with at least 2 years maturity remaining. Column (7) excludes loans for which the lead lender does not retain any part of its share. Columns (8) and (9) expand the sample by including information on covenant compliance from Nini, Smith, and Sufi (2012) and from DealScan, respectively. The dependent variable is the percent change in total committed credit aggregated across all loans in the SNC universe to borrower f. Bad Lender is the rank of the lead lender's health normalized to lie on the unit interval, with a value of 1 corresponding to the least healthy lender. Bind is an indicator variable equal to 1 if a borrower violated a covenant in either the current or previous year. Reported coefficients are multiplied by 100. Borrower controls: log assets, leverage, risk rating. Standard errors two-way clustered by borrower and lead lender reported in parentheses. $*, * *, * * *$ indicate significance at the 10,5 , and 1 percent levels, respectively. 


\section{O.2. Causal Identification in the Near Violation Threshold Sample}

This appendix formalizes the claim in the text that the close violator sample can identify the causal impact of lender health on a covenant violation even if borrowers differentially attempt to manipulate violation status. The argument and notation closely follow Lee and Lemieux (2010).

Let $W_{b, f}$ measure the (possibly unobserved) quality of firm $f$ that borrows from bank $b . W$ is drawn from a distribution that may be lender-specific. For simplicity, suppose covenants are written uniformly by each lender but may differ across lenders. Let $X_{f}$ be the variable on which the covenant is written, $c_{b}$ the threshold for bank $b$, and $D_{f}$ an indicator for firm $f$ violating a loan. The true causal model is:

$$
\begin{aligned}
Y_{b, f} & =\tau_{b} D_{f}+\delta_{1} W_{b, f}+U_{b, f}, \\
D_{f} & =\mathbb{I}\left\{X_{f} \leq c_{b}\right\} \\
X_{f} & =\delta_{2, b} W_{b, f}+V_{f} .
\end{aligned}
$$

Equation (O.1) is the outcome equation and captures the possibility of a heterogeneous response to covenant violations through the lender-specific coefficient $\tau_{b}$. Equation $(\mathrm{O} .2)$ is the covenant status assignment equation. Equation (O.3) relates borrower quality to the variable on which the covenant is written. The $b$ subscript on $\delta_{2}$ accommodates the possibility that borrowers of lenders with larger $\tau_{b}$ work harder to manipulate the variable $X_{f}$.

We make no assumptions on the correlation structure of $W, U, V$, or the correlation of the borrower quality distribution for bank $b$ and $\tau_{b}$. In particular, unobserved borrower quality $W_{b, f}$, which influences outcomes directly, may be correlated with $\tau_{b}$. Instead, we assume only:

Assumption 1 Imprecise control: Conditional on $W=w, U=u$, and lender $b$, the density of $V$ (and hence $X)$ is continuous.

Under Assumption 1, $\operatorname{Pr}\left\{W_{b, f}=w, U_{b, f}=u \mid X_{f}=x\right\}=g_{b}\left(x \mid W_{b, f}=w, U_{b, f}=u\right) \frac{\operatorname{Pr}\left\{W_{b, f}=w, U_{b, f}=u\right\}}{g_{b}(x)}$, where $g_{b}($.$) and g_{b}(. \mid$.$) are marginal and conditional densities for X$ at bank $b$. In particular, $\operatorname{Pr}\left\{W_{b, f}=w, U_{b, f}=u \mid X_{f}=x\right\}$ is continuous in $x$. Therefore:

$$
\begin{aligned}
& \lim _{\epsilon \uparrow 0} E\left[Y_{b, f} \mid X_{f}=c_{b}+\epsilon\right]-\lim _{\epsilon \downarrow 0} E\left[Y_{b, f} \mid X_{f}=c_{b}+\epsilon\right] \\
& =\tau_{b}+\left(\lim _{\epsilon \uparrow 0}-\lim _{\epsilon \downarrow 0}\right) \int\left(\delta_{1} w+u\right) \operatorname{Pr}\left\{W_{b, f}=w, U_{b, f}=u \mid X_{f}=c_{b}+\epsilon\right\} d x=\tau_{b} .
\end{aligned}
$$


It follows that any relationship between $\tau_{b}$ and the health of lender $b$ is non-parametrically identified.

\section{O.3. Details of Sample Construction and Variable Defini- tions}

This appendix gives additional details on how we construct the main sample and the variables used for our analysis. The variables used in this paper are extracted from four major data sources: the Shared National Credit Program (SNC), Loan Pricing Corporation's (LPC) Dealscan database, COMPUSTAT, and Capital IQ. For each data item, we indicate the relevant source in square brackets.

To construct our sample, we start with the universe of loans to firms incorporated in the United States that are included in the supervisory review, which covers about $1 / 3$ of the loan volume in the SNC universe each year. Starting in 2006, loans in the supervisory review contain information on covenants and compliance as well as loan (non-price) terms and borrower characteristics. Supervisors gather this information from loan documentation and follow up directly with the banks when needed, such as in instances when the information is either missing or incomplete.

The SNC supervisory review sample is "weighted toward non-investment grade and criticized credits," a category which comprises a relatively broad range of all credits that are below the highest ("pass") rating - i.e., both so-called special mention and classified credits. ${ }^{1}$ Under the Uniform Loan Classification Standards, classified credits have well-defined weaknesses, including default in some cases. Special mention credits exhibit potential weaknesses, which may result in further deterioration if left uncorrected. Two important considerations merit mention. First, while the sample over-weights non-investment grade and criticized credits, it also contains many passing credits. For example, in the pre-crisis period (2006-2007) the share of credits to nonfinancial borrowers with the highest rating ("pass") is about $91 \%$ in the SNC universe and $73 \%$ in the covenant review sample. Second, the over-weighting occurs on a single dimension - the loan rating - which is observed in the entire SNC universe. These features allow us to re-weight the covenant review sample to be representative of the SNC universe when we do our aggregation exercise. Importantly, there are no other selection criteria. For example, manufacturing firms

\footnotetext{
${ }^{1}$ See https://www.federalreserve.gov/newsevents/pressreleases/bcreg20110825a.htm.
} 
account for $17 \%$ of the SNC universe and $16 \%$ of the covenant review sample. Firms in service sectors account for $33 \%$ of the SNC universe and $29 \%$ of the covenant review sample. About $44 \%$ of loans in the SNC universe and $38 \%$ of loans in the covenant review sample are for working capital or capital expenditures. Loans for project or trade financing are about $4 \%$ in both samples. Loans for debt repayment or consolidation are about 5\% in the SNC universe and about $4 \%$ in the SNC review. Loans for mergers and acquisitions are about $9 \%$ in the SNC universe and about $15 \%$ in the SNC review. On average, loans in the SNC review are a bit larger than those in the SNC universe, but the differences are not large (\$350M vs $330 \mathrm{M})$.

Because information on covenants is available only from 2006, we focus our attention on the sample of loans between 2006 and 2011. The basic unit of observation in SNC is a credit, which is comparable to a deal or package in Dealscan. SNC provides information on covenant compliance for each credit-year surveyed. Each credit-year in SNC is classified as either non-compliant if the borrower has breached a covenant threshold as of the end of the year, or compliant if the borrower has not breached any covenant threshold as of the end of the year, or compliant after receiving a waiver or an amendment if the borrower has not breached a covenant threshold after it was reset, but would have otherwise breached it (if it had not been reset) as of the end of the year. We classify a firm's loan covenants to be binding in a given year if the firm is either non-compliant or compliant after receiving a waiver or an amendment on one of its credits in that year.

While conceptually straightforward, the measurement of covenant violations poses several challenges. Specifically, SNC allows us to deal with four main measurement issues following the standard practice in the literature. First, firms can have multiple loan deals during a given year in our sample period. For the case when multiple deals overlap (i.e., one deal matures after the start of another deal) and the analysis is at the borrower level, we define covenant compliance to be the tightest (i.e., we classify a borrower covenants to be binding if they are binding on at least one of the borrowers' credits in any given year) unless it corresponds to a refinancing deal, in which case we define the relevant covenant status to be that specified by the refinancing credit regardless of whether or not it is tightest. Second, for the case when there are dynamic covenants that change over the life of the loan, SNC includes complete information on the covenant dynamics, which we use to define the compliance status over the life of the loan accordingly. Third, SNC also includes complete information on post-origination amendments to the loan contract, which we also use to define compliance status over the life of a loan. Finally, since our data has a lower annual (and not 
quarterly) time frequency than existing studies, we opted for including a relatively small fraction (number) of the newly originated loans, 5.6\% (181), that are classified as non-compliant in the year of the loan origination, a phenomenon also encountered by Dichev and Skinner (2002) and Chava and Roberts (2008).

Finally, we retrieved information on loan pricing from Dealscan, as well as borrower balance sheet information from Compustat for publicly-traded firms and from Capital IQ for privately-held firms. The final step of our data assembly process is to merge the SNC loan data with information from these sourced by matching company names. Firms in the SNC universe were compared to firms in each of these additional data sources using a standard matching algorithm (see, for example, Lee and Mas (2012)), which is the SAS SPEDIS function. This function matches company names in each of the additional data sources to company names in SNC based on a "spelling distance," which considers those comparisons with a spelling distance below a predetermined threshold as candidate matches. For the cases when the algorithm matches a company in SNC to more than one company name in any of the additional data files, we selected the lowest spelling distance as the candidate match. Research assistants reviewed every match and manually dropped those where, based on company headquarter location (state and city) and web searches from multiple sources including company web sites, Lexis-Nexis, Google, and Factiva, they assessed that the automated procedure resulted in an incorrect match. As a final quality check of the matching procedure, we retrieved an additional match file by using the same procedure for the DealscanCompustat linking file from Chava and Roberts (2008), which is available at Michael Robert's web page, and verified that the resulting firm identifiers (gvkeys) were the same as those from our merge with Dealscan.

The variables used in the analysis are defined as follows.

\section{Main Explanatory Variables:}

Bind is a dummy that takes value of one for any given loan-year when the borrower is either noncompliant with any of its loan covenants or compliant after receiving a waiver or an amendment in a given year, i.e., if the borrower either breaches a covenant threshold in any given firm-year or a covenant is reset or waived so that an otherwise non-compliant borrower would remain in compliance. $[\mathrm{SNC}]$

Bad Lender is based on Chodorow-Reich (2014) and is the cumulative density (cdf) of the 
beginning-of-the-period lead-lender exposure to asset-backed securities as measured by the correlation of their daily stock return with the return on the ABX AAA 2006-H1 index (ABX Exposure), to balance sheet losses not directly affected by the corporate loan portfolio as measured by the ratio of 2007-2008 trading account losses to total assets (B/S Exposure), and to the Lehman failure as measured by the fraction of a bank's syndication portfolio where Lehman Brothers had a lead role (LEHMAN Exposure), in turn. We use factor analysis to aggregate over these individual exposure proxies and extract an overall exposure proxy which is measured as the cumulative density (cdf) of the (first) principal component of the three individual proxies calculated using the entire SNC universe $(A L L)$.

\section{Outcome Measures:}

Credit Reduced is a dummy that equals one for either existing loans that end before their most recently stated maturity in a given year and are not followed by a new loan to the borrower from the current lead lender or for existing loans that experienced a reduction in the total dollar amount limit the borrower is legally allowed to borrow up to according to the loan contract terms in a given year relative to the previous year. We are able to track loan paths over time because each loan in $\mathrm{SNC}$ is assigned a unique permanent credit identifier, which remains unchanged throughout the life of the loan including in those years when loan terms are amended or modified or when the loan is refinanced. [SNC]

Waiver is a dummy that equals one if any of the loan covenants are waived or reset in a given year. [SNC]

Lead Share (Committed) is the ratio of the dollar amount limit the lead lender is legally committed to lend divided by the total dollar amount limit the borrower is legally allowed to borrow according to the loan contract terms in a given year. [SNC]

Lead Amount (Committed) is the natural logarithm of the dollar amount limit the lead lender is legally committed to lend up to according to the loan contract terms in a given year. [SNC]

Lender Share (Committed) is the ratio of the dollar amount limit the lender is legally committed to lend divided by the total dollar amount limit the borrower is legally allowed to borrow according to the loan contract terms in a given year. [SNC]

Lender Amount (Committed) is the natural logarithm of the dollar amount limit the lender is legally committed to lend up to according to the loan contract terms in a given year. [SNC] 
Loan Utilization Rate is the ratio of the loan balance (the dollar amount the borrower has drawn which has not been repaid) divided by the total dollar amount limit the borrower is legally allowed to borrow according to the loan contract terms in a given year. [SNC]

Payouts/Assets is dividends (item 21) plus net-repurchases divided by lagged total book assets (item 6). Net-repurchases are stock purchases (item 115) minus stock issuances (item 108) and are set to zero if negative. [Compustat]

Capex/Assets is capital expenditures (item 128) divided by lagged total book assets (item 6). [Compustat]

Employment Growth is the ratio of the total number of employees (item $29_{t}$ ) minus the lagged total number of employees (item $29_{t-1}$ ) divided by the lagged total number of employees (item $\left.29_{t-1}\right)$. [Compustat]

Bond Issuance/Assets is total dollar proceeds from new issuance of bonds divided by lagged total book assets (item 6) [FISD \& Compustat]

Firm and Industry Variables:

Sample-Split Variables:

Credit line is a dummy variable for whether the loan is a credit line. [SNC]

High Lead Share is a dummy variable for whether the lead share is above the sample median in a given year. [SNC]

Small Syndicate is a dummy variable for whether the number of syndicate members is below the sample median in a given year. $[\mathrm{SNC}]$

Concentrated Syndicate is a dummy variable for whather the Herfindahl index of loan commitment shares (calculated as the sum of squared shares across lenders) is above the sample median in a given year. $[\mathrm{SNC}]$

Additional Controls:

Loan origination year is a full set of dummies that equal one for each year in which any given loan was originated. [SNC]

Loan purpose is a full set of dummies that equal one for each of the loan purpose categories included in SNC, such as, for example, M\&As, CAPEX, working capital, general corporate purposes. [SNC] Loan type is a full set of dummies that equal one for each of the loan type categories included in SNC, such as, for example, term loan, revolving credit, non-revolving line of credit. [SNC] 
Borrower sector is a full set of dummies that equal one for each of the 8 borrower sector categories included in SNC, such as, for example, manufacturing, services, distribution. [SNC]

Loan size is the natural logarithm of the total dollar amount limit the borrower is legally allowed to borrow up to according to the loan contract terms in a given year. [SNC]

Borrower size is the natural logarithm of the book value of assets. [SNC]

Leverage is the ratio of total book debt to book value of assets. [SNC]

Risk rating is an indicator variable equal to 1 if the supervisory risk rating assigned to the loan is "Pass". There are five possible supervisory risk rating categories: Pass (for loans that are considered to be in good standing), Special Mention (for loans that are in good standing but have potential weaknesses that, if left uncorrected, could result in further deterioration of the repayment prospects), Substandard (for loans that are inadequately protected by the current sound worth and paying capacity of the borrower or of the collateral pledged, if any), Doubtful (for loans that are considered substandard and, in addition, have weaknesses that make collection or liquidation in full, on the basis of available current information, highly questionable or improbable), and Loss (for loans that are considered uncollectible and of so little value that their continuance as bankable assets is not warranted and, as such, should be promptly charged off). [SNC]

Cash flows is the ratio of income before extraordinary items plus depreciation and amortization (item 18+item14) over lagged total book assets (item 6). [Compustat]

Return on assets (ROA) is the ratio of operating income after depreciation (item 178) over lagged total assets (item 6).[Compustat]

Tobin's $Q$ is the market value of assets divided by the book value of assets (item 6), where the market value of assets equals the book value of assets plus the market value of common equity less the sum of the book value of common equity (item 60) and balance sheet deferred taxes (item 74). [Compustat]

Z-score is the Altman's Z-Score, which is defined as the sum of 3.3 times pre-tax income, sales, 1.4 times retained earnings, and 1.2 times net working capital all divided by total assets (itme 6). [Compustat]

Discretionary accruals are defined as Accruals DD in Chava and Roberts (2008). [Compustat] SESP credit rating is a dummy variable that takes the value of one if the firm has an S\&P LongTerm Domestic Issuer Credit Rating [Compustat]

Bankruptcy or delisting is a dummy based on the delisting code [CRSP-Compustat] 
Market beta is the estimated slope coefficient on the market excess return from projecting the firm excess return on the market excess return using daily stock return data. We obtain annual estimates by annualizing the average of monthly estimates. [CRSP]

Idiosyncratic volatility is the variance of estimated residuals from projecting the firm excess return on the market excess return using daily stock return data. We obtain annual estimates by annualizing the average of monthly estimates.[CRSP]

Total volatility is the variance of the firm excess return using daily stock return data. We obtain annual estimates by annualizing the average of monthly estimates.[CRSP]

Excluded instruments:

New Route is a dummy that takes value of one for introduction of a new airline route that reduces the travel time between the borrower and the lender in the year of loan origination, similar to Giroud (2013) and Bernstein, Giroud, and Townsend (2016), to which we refer for additional details. Location is headquarter county. Data on airline routes is from the T-100 Domestic Segment Database, which is compiled from Form 41 of the U.S. Department of Transportation (DOT). All airlines operating flights in the United States are required by law to file Form 41 with the DOT. For all flights that have taken place between any two airports in the United States, the T-100 contains (monthly) data for each airline and route (segment) on the origin and destination airports, flight duration (ramp-to-ramp time), and scheduled and performed departures. We define New Route as an indicator variable that equals one if a new airline route is introduced that reduces the travel time between the borrower and the lender in the year of loan origination. [DOT]

Airline Bankruptcy is exposure to an airline bankruptcy for the primary route that connects the borrower and the lender in the year of loan origination. Location is headquarter county. Data on airline routes is from the T-100 Domestic Segment Database, which is compiled from Form 41 of the U.S. Department of Transportation (DOT). All airlines operating flights in the United States are required by law to file Form 41 with the DOT. For all flights that have taken place between any two airports in the United States, the T-100 contains (monthly) data for each airline and route (segment) on the origin and destination airports, flight duration (ramp-to-ramp time), and scheduled and performed departures. Data on major airlines bankruptcies is hand-collected from the airlines' public filings with the SEC, which we cross-check with corporate announcements from the CapitalIQ Key Developments Dataset. We include the following major airline bankruptcies (bankruptcy process dates in parentheses): Delta (Sept 14 2005-April 30 2007), Northwest (Sept 
14 2005-May 31 2007), United (Dec 9 2002-Dec1 2006), US Air (Aug 11 2002-Mar 31, 2003; Sept 12 2004-Sept 27 2005). [DOT and SEC filings]

Lax Supervisor is a dummy that equals one if the supervisory institution in the quarter of loan origination is lax, similar to Agarwal et al. (2014), to which we refer for additional details. We use the National Information Center (NIC) of the Federal Reserve System to retrieve information about lead examiner institutions' identity (e.g. FDIC, Fed, States, and OCC) and dates for each lead lender in our sample. We employ the information at the level of the commercial bank. [NIC]

Abnormal Snow is the rank-noramlized abnormal snow cover in a given borrower county-year calculated for current year Q1 and Q4 relative to the average weather in the same county Q1 and Q4 for the past 10 years similar to Brown, Gustafson, and Ivanov (forthcoming), to which we refer for additional details. Specifically, we construct the measure using county-level data on daily snow cover (in inches) from the National Oceanic and Atmospheric Administration (NOAA)'s website, which reports daily snow cover (SNWD) for each weather station in the United States. For each day and county, we first compute the median value of snow cover across weather stations to mitigate the effect of weather in high elevation geographic areas. We then calculate the average of daily snow cover in each county-quarter. We aggregate these values into a baseline average of snow cover in the first and fourth calendar quarters for each county-year using data from the previous 10 years. Abnormal Snow is defined as the rank-normalization of the difference between the average daily snow cover during the first and fourth quarters in a given county-year minus the county's average daily snow cover in the first and fourth quarters during the previous ten years. [NOAA]

\section{References}

Agarwal, Sumit, David Lucca, Amit Seru, and Francesco Trebbi (2014). "Inconsistent Regulators: Evidence from Banking". The Quarterly Journal of Economics 129 (2): 889-938.

Bernstein, Shai, Xavier Giroud, and Richard R. Townsend (2016). "The Impact of Venture Capital Monitoring". The Journal of Finance 71 (4): 1591-1622.

Brown, James, Matthew Gustafson, and Ivan Ivanov (forthcoming). "Weathering Cash Flow Shocks". The Journal of Finance.

Chava, Sudheer and Michael Roberts (2008). "How Does Financing Impact Investment? The Role of Debt Covenants". The Journal of Finance 63 (5): 2085-2121. 
Chodorow-Reich, Gabriel (2014). "The Employment Effects of Credit Market Disruptions: Firmlevel Evidence from the 2008-9 Financial Crisis". The Quarterly Journal of Economics 129 (1): $1-59$.

Dichev, Ilia D. and Douglas J. Skinner (2002). "Large-Sample Evidence on the Debt Covenant Hypothesis". Journal of Accounting Research 40 (4): 1091-1123.

Giroud, Xavier (2013). "Proximity and Investment: Evidence from Plant-Level Data". The Quarterly Journal of Economics 128 (2): 861-915.

Lee, David S. and Thomas Lemieux (2010). "Regression Discontinuity Designs in Economics". Journal of Economic Literature 48 (2): 281-355.

Nini, Greg, David C. Smith, and Amir Sufi (2012). "Creditor Control Rights, Corporate Governance, and Firm Value". Review of Financial Studies 25 (6): 1713-1761. 